\title{
BOSNIA AND HERZEGOVINA
}

\section{Diagnostic Review of Consumer Protection and Financial Literacy in Banking Services}

\section{Volume II \\ Comparison with Good Practices}

[April 2011]

Commissioned by the Ministry of Finance and Treasury

of Bosnia and Herzegovina 


\title{
BOSNIA AND HERZEGOVINA
}

\section{Diagnostic Review of Consumer Protection and Financial Literacy in Banking Services}

\author{
Volume II \\ Comparison against Good Practices
}

\section{Contents}

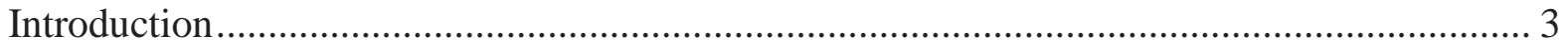

Overview of the BiH Financial Sector ............................................................................... 4

Overview of the BiH Banking Sector .............................................................................. 7

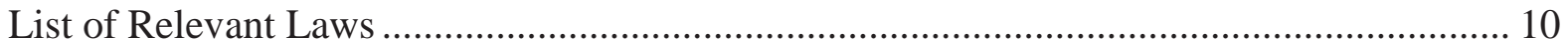

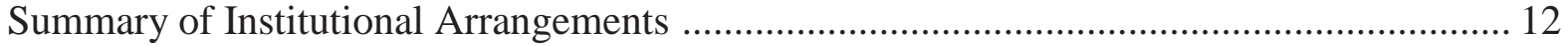

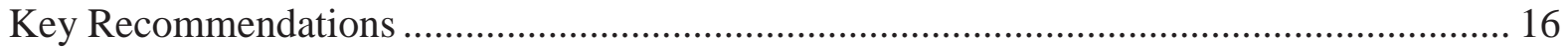

Good Practices: Banking Sector ................................................................................. 18

\section{Tables}

Table 1: Access to Banking Services ................................................................................. 4

Table 2: Efficiency of Systems for Enforcing Contracts in Europe ..................................... 5

Table 3: Maturity of Households Loans in 2008 .............................................................. 9

\section{Figures}

Figure 1: Cross-Country Comparison of Credit Reporting Systems Coverage ....................... 5

Figure 2: Cross-Country Comparison of Banking Sector Size in 2008............................... 7

Figure 3: Share Capital of the BiH Banking System by Country in 2008 ............................. 7

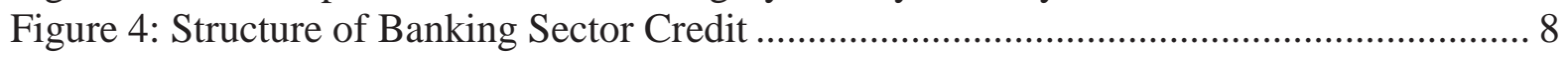

Figure 5: Contribution to Banking Sector Credit Growth ................................................. 8 


\section{Introduction}

With the exception of Brčko District in the northeast, ${ }^{1}$ Bosnia and Herzegovina $(\mathrm{BiH})$ consists of two largely autonomous administrative Entities, namely the Bosniac-Croat Federation, also known as the Federation of Bosnia and Herzegovina (FBiH), and the Republika Srpska (RS). These Entities are responsible for most policy formulation and resulting legislative enactments, as well as for the application and enforcement of these enactments within their respective borders.

The Constitution of the State of $\mathrm{BiH}$ granted weak powers to the State of $\mathrm{BiH}$, with most powers accorded to the two Entities. ${ }^{2}$ The Constitution of the State of BiH was agreed at Dayton as Annex 4 of the General Framework Agreement for Peace on 14 December 1995. The RS and the FBiH were confirmed as Entities of $\mathrm{BiH}$. Bosniacs, Serbs and Croats were described as "constituent peoples". ${ }^{3}$ At the State-level, power-sharing arrangements were introduced, making it impossible to reach decisions against the will of the representatives of any constituent people. A vital interest veto for all three constituent peoples was established in both chambers of parliament and a collective Presidency of three members with a Serb from the RS and a Bosniac and a Croat from the FBiH.

Following considerable delay, as a result of concerns about the capacity of $\mathrm{BiH}$ to harmonize its policies and laws with those of the EU, a Stabilization and Association Agreement was signed between $\mathrm{BiH}$ and the $\mathbf{E U}$ in June 2008. However difficult, it remains incumbent upon $\mathrm{BiH}$ to make progress in adopting common rules, standards and policies that make up European Union law. ${ }^{4}$ And these common rules, standards and policies apply in matters of consumer protection, as they do in a great many other fields.

\footnotetext{
${ }^{1}$ Brčko District is a 173 square mile, neutral, self-governing administrative unit, under the sovereignty of Bosnia and Herzegovina. ${ }^{2}$ By Article III.1 of the State Constitution, the responsibilities of the State are extremely narrow. Also, according to Article III.3 (a): "All governmental functions and powers not expressly assigned in this Constitution to the institutions of Bosnia and Herzegovina shall be those of the Entities." The weakness of the State is also confirmed by Article VIII.3 on Finances which makes the State dependent on contributions from the Entities: "The Federation shall provide two-thirds, and the Republika Srpska one-third, of the revenues required by the budget, except insofar as revenues are raised as specified by the Parliamentary Assembly. "Furthermore, the only Court explicitly provided for at the State level is the Constitutional Court.

${ }^{3}$ For purposes of this Report, "Bosnians" means all constituent peoples and all other citizens of BiH.

${ }^{4}$ To gain membership in the EU, the so-called 'Copenhagen criteria' established by the European Council in 1993 must be satisfied. Besides adopting the common rules and standards comprising European Union law, this requires BiH to achieve stable democracy status, to guarantee the rule of law, human rights and respect for and protection of minorities, as well as to demonstrate the existence of a functioning market economy, and the capacity to cope with competitive pressures and market forces within the EU. In addition, the specific priorities identified in the European Partnership with BiH entered into in November 2007 must also be met.
} 


\section{Overview of the BiH Financial Sector}

The BiH financial system is largely dominated by the banking sector. Banking sector assets grew at rates of 28 percent in 2006 and 34 percent in 2007. In 2008, however, the growth rate significantly decreased to 6 percent. In 2009 however the banking sector assets decreased by only 1 percent, a trend that continued in 2010. Still, at the end of 2010, the banking sector represented 84 percent of the total assets of the financial sector.

Table 1: Assets of Financial Institutions in BiH

(as percent of GDP)

\begin{tabular}{lrrrrrr}
\hline Financial Institutions & $\mathbf{2 0 0 5}$ & $\mathbf{2 0 0 6}$ & $\mathbf{2 0 0 7}$ & $\mathbf{2 0 0 8}$ & $\mathbf{2 0 0 9}$ & $\mathbf{2 0 1 0}$ \\
\hline Banks & 67.58 & 76.46 & 89.94 & 84.21 & 85.85 & 86.51 \\
Investment funds & 10.57 & 8.11 & 8.09 & 4.96 & 3.63 & 3.76 \\
Leasing companies & 3.90 & 5.39 & 6.34 & 6.50 & 5.90 & 4.69 \\
Insurance and reinsurance & 3.99 & 3.70 & 3.92 & 3.60 & 3.92 & 3.99 \\
Microcredit organizations & 1.85 & 2.54 & 4.35 & 4.91 & 4.53 & 3.63 \\
\hline Total & $\mathbf{8 7 . 9 0}$ & $\mathbf{9 6 . 1 8}$ & $\mathbf{1 1 2 . 6 4}$ & $\mathbf{1 0 4 . 1 8}$ & $\mathbf{1 0 3 . 8 3}$ & $\mathbf{1 0 2 . 5 8}$ \\
\hline
\end{tabular}

Source: $\mathrm{CBBiH}$

At the same time, relatively few Bosnians make use of formal financial services. Initial estimates from the World Bank in 2003 were that only 17 percent of Bosnians then had an account with any financial intermediary. According to the Living Standards Measurement Survey carried out in 2004, 15 percent of Bosnian households were indebted in financial institutions. More recently, it has been estimated that less than 40 percent of $\mathrm{BiH}$ adults have a bank deposit account, one of the lowest rates in the region.

Table 2: Access to Banking Services

\begin{tabular}{|c|c|c|c|c|}
\hline & $\begin{array}{c}\text { Number of Bank } \\
\text { Deposit } \\
\text { Accounts } \\
\text { (per thousand } \\
\text { adults) }\end{array}$ & $\begin{array}{c}\text { Value of Bank } \\
\text { Deposits } \\
\text { (as percentage of } \\
\text { GDP) }\end{array}$ & $\begin{array}{c}\text { Number of Bank } \\
\text { Deposit } \\
\text { Accounts } \\
\text { (per thousand } \\
\text { adults) }\end{array}$ & $\begin{array}{c}\text { Value of Bank } \\
\text { Deposits } \\
\text { (as percentage of } \\
\text { GDP) }\end{array}$ \\
\hline & \multicolumn{2}{|c|}{2009} & \multicolumn{2}{|c|}{2010} \\
\hline $\begin{array}{l}\text { Bosnia and } \\
\text { Herzegovina }\end{array}$ & 380.4 & 53.89 & n.a. & 49.74 \\
\hline Latvia & $1,218.60$ & 74.9 & $1,205.16$ & 55.91 \\
\hline Slovenia & $1,393.60$ & 74.89 & $1,380.42$ & 102.07 \\
\hline Croatia & n.a. & 97.83 & $1,441.51$ & 70.1 \\
\hline $\begin{array}{l}\text { Poland } \\
\text { Czech }\end{array}$ & $1,527.40$ & 48.57 & $1,626.41$ & 30.27 \\
\hline $\begin{array}{l}\text { Republic } \\
\text { Slovak }\end{array}$ & $1,679.60$ & 87.91 & $1,739.26$ & 62.91 \\
\hline Republic & n.a. & 47.63 & $1,857.83$ & 62.73 \\
\hline Bulgaria & $1,987.30$ & 66.75 & $2,005.78$ & 51.78 \\
\hline Hungary & $1,570.80$ & 51.38 & $2,058.27$ & 38.06 \\
\hline Estonia & $2,751.90$ & 81.51 & $2,669.14$ & 70.95 \\
\hline Ukraine & $3,755.00$ & 48.58 & $3,145.32$ & 22.03 \\
\hline Lithuania & $2,142.40$ & 42.25 & $4,190.10$ & 34.91 \\
\hline
\end{tabular}

Source: CGAP and World Bank, Financial Access, 2009 
The credit reporting system in $\mathrm{BiH}$ has been developing in recent years. Although the public credit registry is expected to cover almost 35 percent of the adult population by 2012, the private credit bureau coverage is expected to shrink from 64 percent in 2010 to 47 percent in 2011 and 40 percent in 2012. The extent of the combined coverage puts BiH's credit reporting system above the average of other European countries, including Latvia, Slovakia and Romania. The coverage, however, is still not enough to surpass that of Croatia and the Czech Republic (see Figure 1). It is important to note that the private credit bureau in $\mathrm{BiH}$ does include credit information from retailers, trade creditors and utility companies in addition to information from banks and non-bank financial institutions.

Figure 1: Cross-Country Comparison of Credit Reporting Systems Coverage (\% of adults)

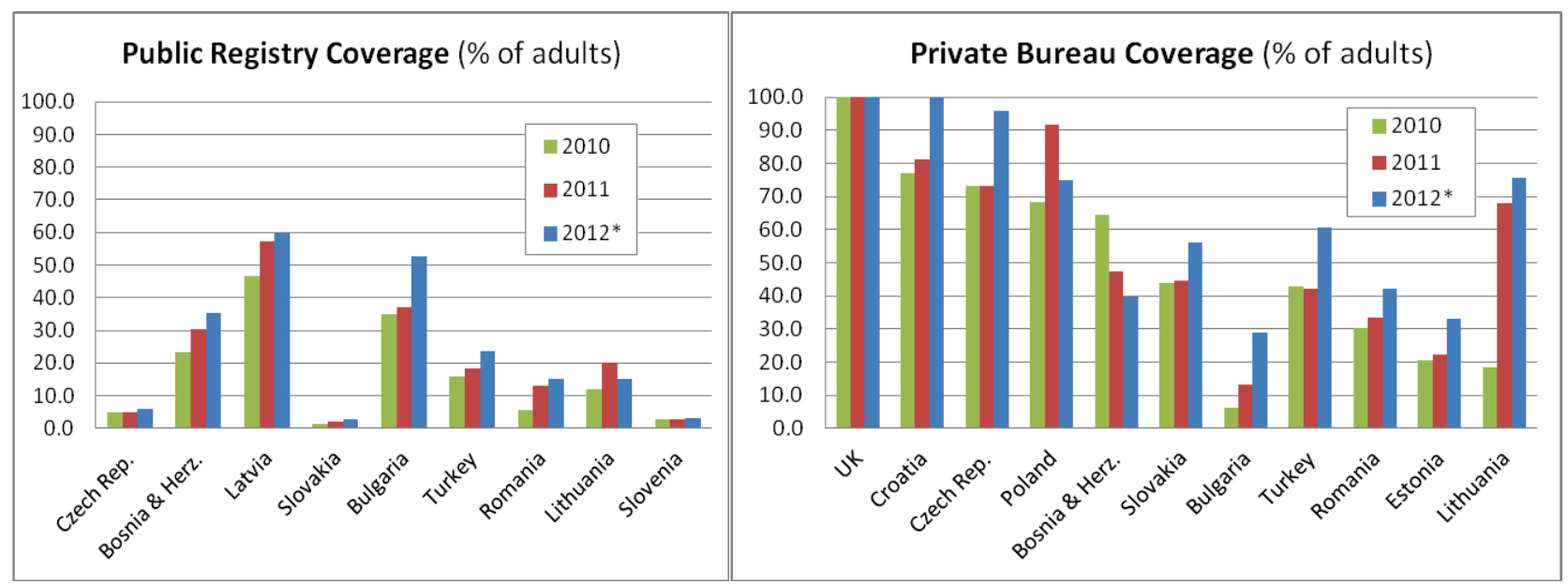

Source: World Bank, Doing Business 2010, 2011, 2012

The efficiency of the system for enforcing contracts in $\mathrm{BiH}$ is below the average of the region. $\mathrm{BiH}$ is ranked $97^{\text {th }}$ in terms of countries with policies to protect investors and 125th in estimated number of days required to enforce contracts (see Table 3). Consistently speedy enforcement of liens on collateral assures lenders that the taking of collateral does constitute effective security when their borrowers default. In terms of cost of enforcement, $\mathrm{BiH}$ has the highest average cost in the region with enforcement eating up to40 percent of the amount being claimed. This average cost is 21 percentage points higher than the average of Central and Eastern Europe (19 percent). Although these statistics correspond to procedures for enforcing commercial contracts, they provide an idea of the efficiency of the system for enforcing other types of contracts as well.

Table 3: Efficiency of Systems for Enforcing Contracts in Europe

\begin{tabular}{lccc}
\hline & $\begin{array}{c}\text { Number of } \\
\text { Procedures }\end{array}$ & $\begin{array}{c}\text { Number of } \\
\text { Days }\end{array}$ & $\begin{array}{c}\text { Cost } \\
\text { (as \% of Claim) }\end{array}$ \\
\hline Latvia & 27 & 369 & 23.1 \\
Czech Republic & 27 & 611 & 33 \\
Lithuania & 30 & 275 & 23.6 \\
Slovakia & 32 & 565 & 30 \\
Romania & 31 & 512 & 28.9 \\
Slovenia & 32 & 1,290 & 12.7 \\
Hungary & 35 & 395 & 15.0 \\
Estonia & 35 & 425 & 22.3 \\
Russia & 36 & 281 & 13.4 \\
Croatia & 38 & 561 & 13.8 \\
Bosnia and Herzegovina & $\mathbf{3 7}$ & $\mathbf{5 9 5}$ & $\mathbf{4 0 . 4}$ \\
Poland & 37 & 830 & 12.0
\end{tabular}




\begin{tabular}{lccc}
\hline Bulgaria & 39 & 564 & 23.8 \\
\hline Central and Eastern Europe & 49 & 450.9 & 19.0 \\
\hline
\end{tabular}

Source: World Bank, Doing Business 2010 


\section{Overview of the BiH Banking Sector}

The size of the BiH banking sector in relation to GDP is similar to neighboring countries. By 2010, the share of BiH's banking sector assets in relation to GDP reached almost 60 percent. This level was higher than that of Kazakhstan (58 percent), Romania (55 percent) and Russia Federation (39 percent), but lower than Czech Republic (65 percent), Ukraine (79 percent) and Croatia (82 percent).

Figure 2: Cross-Country Comparison of Banking Sector Size in 2010

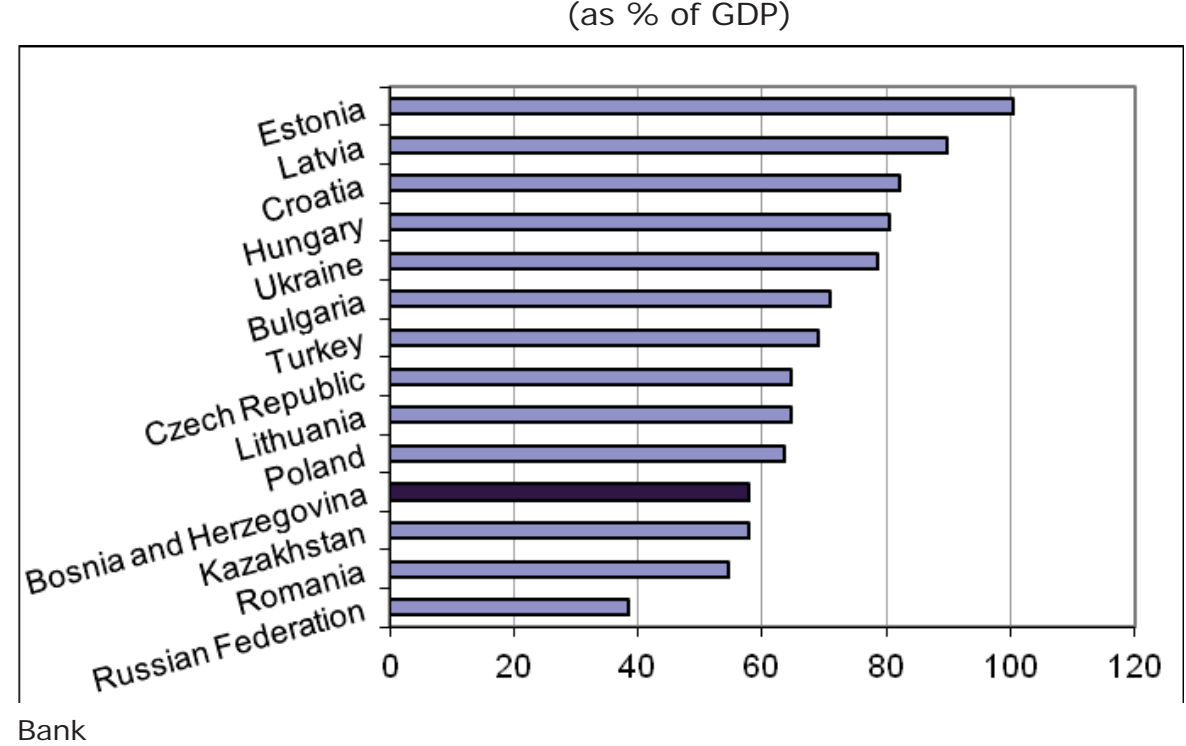

Source: World

The $\mathrm{BiH}$ banking sector is mostly foreign-owned. As of 2010, there were 28 banks operating in $\mathrm{BiH}$ : 18 based in FBiH and 10 in RS. 27 banks are foreign-owned, 7 are domestic private banks and 1 majority state-owned. The ownership structure of the banking system by end-2009 indicated that almost 95 percent of total assets and 88 percent of average equity capital was held by foreign-owned banks, whereas in 2008 these percentages were 95 and 88, respectively. According to statistics from the Central Bank, 62 percent of foreign capital invested in the banking system in 2010 came from Austrian investors (see Figure 3).

Figure 3: Share Capital of the BiH Banking System by Country in 2009

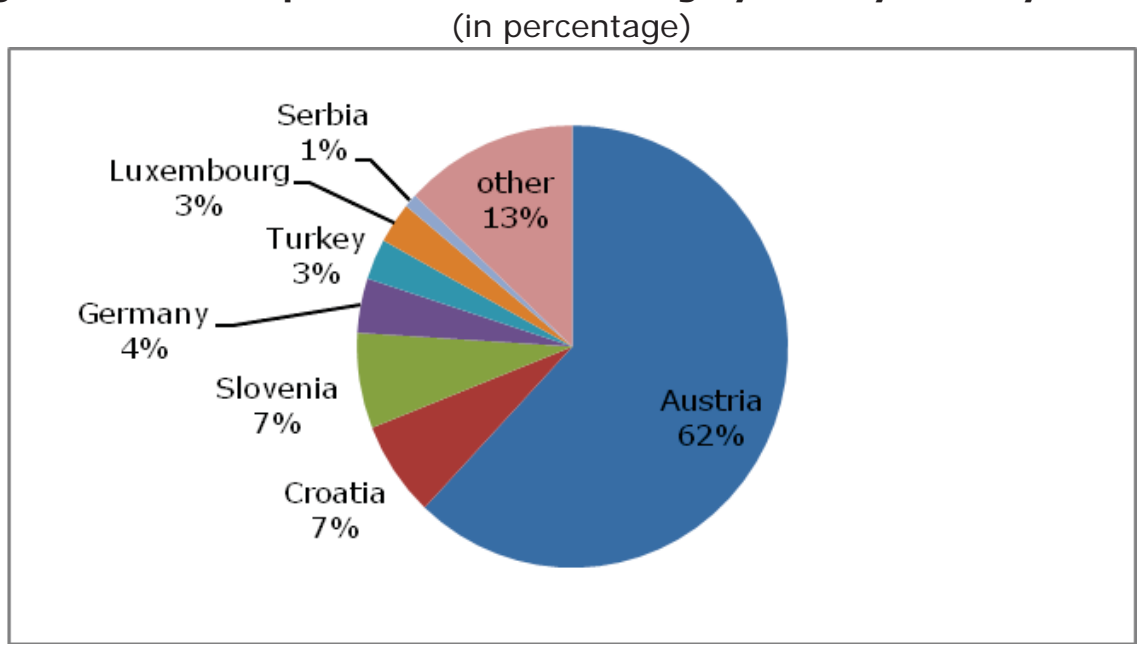

Source: $\mathrm{CBBiH}$ 
The expansion of the banking sector has been driven by credit to households. The banking sector credit portfolio grew at an average annual rate of 25 percent from 2004 to 2008, but experienced a drop of 5 per cent from 2008 to 2009, which was the first loan decline in ten years; this loan decline continued through the first half of 2010 as well. Over the years, credit to the household sector has increased its share of the total banking credit portfolio. As of 2008, the debt of households in $\mathrm{BiH}$ (27.1 percent of GDP) was far above the average value of the region (4.6 percent of GDP); however, in $2009 \mathrm{BiH}$ recorded a significant decrease in loans to households (approximately $2 \%$ of GDP).

Figure 4: Structure of Banking Sector Credit

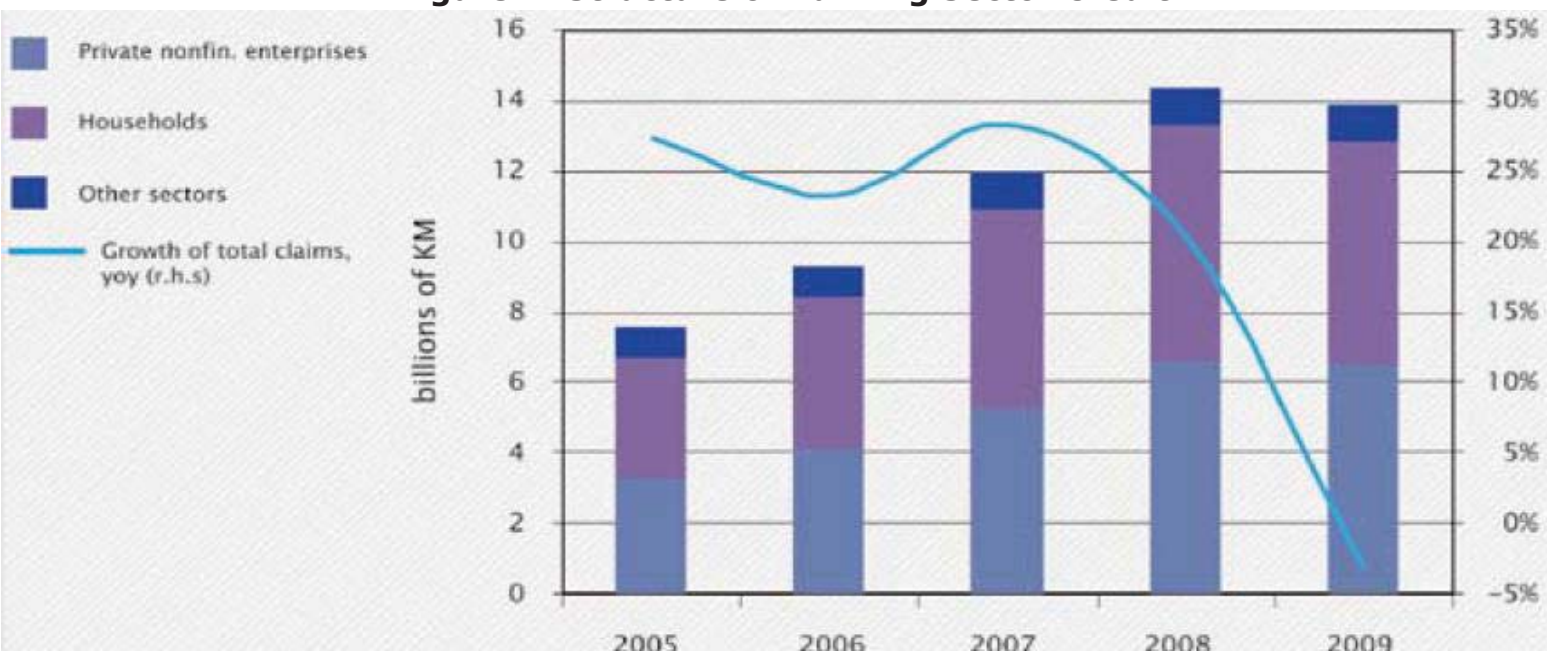

Source: CBBiH, Financial Stability Report, 2009

The increase of long-term lending to households has represented more than 40 percent of the growth in the banking credit portfolio over the past six years. In the same period, short to mediumterm credit to the household sector has grown by more than 50 percent within the same portfolio. The most dynamic component of household credit has been long-term lending. However, in 2008, for the first time, credit to the household sector represented less than 40 percent of the total growth of the banking credit portfolio. Further, in 2009 decrease in the household credit portfolio was the main responsible in the overall decrease in banking sector credit growth.

Figure 5: Contribution to Banking Sector Credit Growth (in percentage)

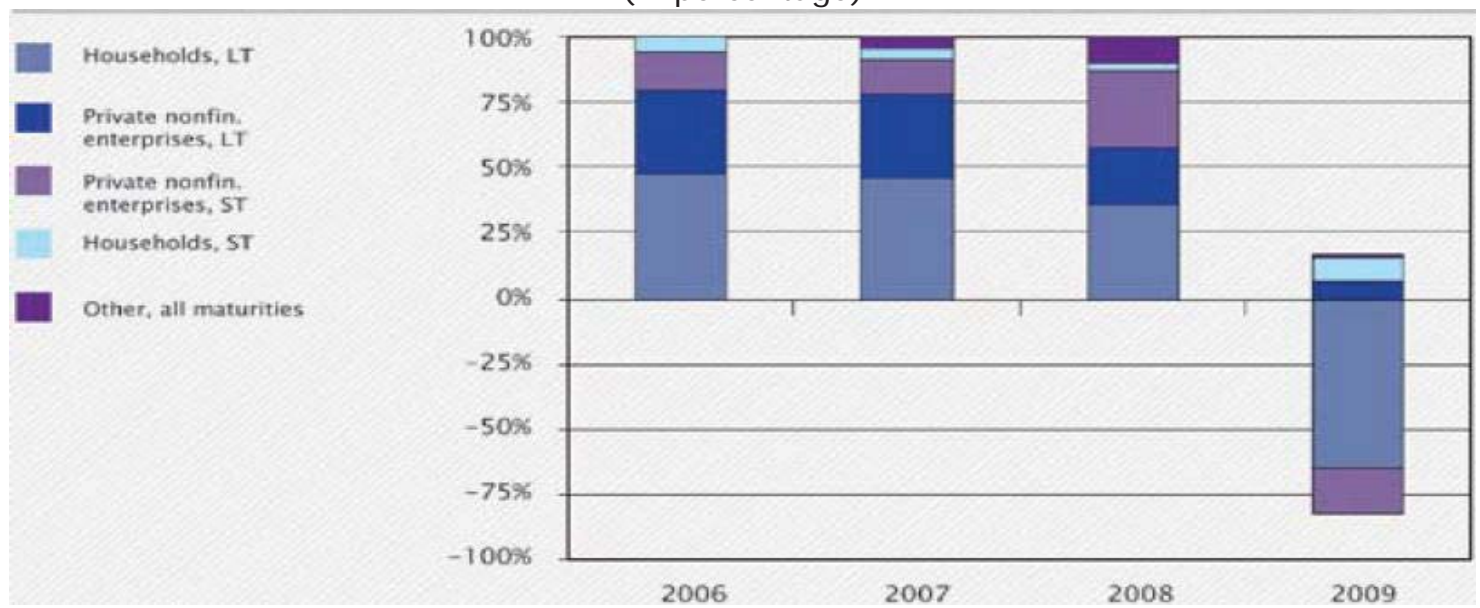

Source: CBBiH, Financial Stability Report, 2009 
There is a significant source of risk in the household loan portfolio of the banking sector. Most household loans are long-term, mainly indexed and with a variable interest rate. As seen in Table 4, more than half of the loans extended to households are for 5 years or more, with almost 40 percent of the loans for more than 10 years. Further, the impact of the financial crisis on households can be gauged from the drop in total loans by 10\% from 2008 to 2009, which has been stable at almost the same level in 2010 .

Table 4: Maturity of Households Loans in 2008

\begin{tabular}{|c|c|c|c|c|c|c|c|c|c|c|c|c|}
\hline & \multicolumn{4}{|c|}{2010} & \multicolumn{4}{|c|}{2009} & \multicolumn{4}{|c|}{2008} \\
\hline & $\mathbf{K M}$ & Euro & $\mathrm{CHF}$ & Total & $\mathbf{K M}$ & Euro & $\mathrm{CHF}$ & Total & $\mathbf{K M}$ & Euro & $\mathrm{CHF}$ & Total \\
\hline up to 1 year & 48 & 7 & 3 & 58 & 621 & 35 & 0 & 655 & 70 & 8 & 0 & 79 \\
\hline 1 - 3 years & 224 & 83 & 8 & 315 & 692 & 67 & 2 & 762 & 270 & 194 & 1 & 465 \\
\hline 3 - 5 years & 560 & 134 & 2 & 696 & 666 & 208 & 31 & 906 & 677 & 261 & 9 & 947 \\
\hline 5 - 10 years & 1,610 & 642 & 39 & 2,290 & 1,319 & 428 & 97 & 1,844 & 1,513 & 963 & 63 & 2,539 \\
\hline over 10 years & 1,090 & 761 & 395 & 2,246 & 1,016 & 219 & 185 & 1,420 & 870 & 821 & 416 & 2,107 \\
\hline TOTAL & 3,532 & 1,627 & 446 & 5,605 & 4,313 & 957 & 316 & 5,587 & 3,401 & 2,247 & 489 & 6,137 \\
\hline
\end{tabular}

Source: CBBiH, Financial Stability Report, 2010, 2009, 2008 


\section{List of Relevant Laws}

While a general law on consumer protection exists at State-level, no such law exists in either Entity, much less a specific law for consumer protection in banking services. Laws regulating the banking industry do, however, exist at Entity-level. The main laws and regulations providing directly or indirectly for consumer protection in the banking sector are the following: ${ }^{5}$

\section{State-level:}

- The Constitution of $\mathrm{BiH}$ adopted on 1 December 1995 by decision of the High Representative

- Consumer Protection Act (Official Gazette of BiH, No. 25/06)

- Law on Competition (Official Gazette of BiH, No. 48/05)

- Criminal Code (Official Gazette of BiH, No. 37/03, 61/04, 30/05, 53/06, 55/06, 32/07 and 8/10)

- The Law on the Central Bank of BiH (Official Gazette of BiH, No. 1/97, 29/02, 8/03, 13/03, 14/03, 9/05, 76/06 and 32/07)

- Law on Deposit Insurance in Banks of BiH (Official Gazette of BiH, Nos. 20/02 and 18/05) as further amended (Official Gazette of BiH, No. 100/08 and 75/09)

- Law on the Protection of Personal Data (Official Gazette of BiH, No. 49/06)

- Law on Obligations (Official Gazette of the Socialist Federal Republic of Yugoslavia, Nos. 29/78, 39/85, 45/89 and 57/89)

- Law on Associations and Foundations (Official Gazette of BiH, Nos. 32/01 and 42/03)

- Law on Market Surveillance (Official Gazette of BiH, No. 45/04)

- Law on Mediation Procedure (Official Gazette of BiH, No. 37/04)

- Law on Transfer of Mediation Affairs onto the Association of Mediators (Official Gazette of $\mathrm{BiH}$, No. 52/05)

\section{Federation of Bosnia and Herzegovina Entity-level:}

- The Constitution of the FBiH (Official Gazette of the FBiH, No. 01/94, 13/97, 16/02, 22/2, 52/02, 18/03, 63/03, 9/04, 20/04, 33/04, 71/05, 72/05 and 88/08)

- Law on Banks (Official Gazette of the FBiH, Nos. 39/98, 32/00, 48/01, 27/02, 41/02, 58/02, 13/03, 19/03 and 28/03)

- Law on the Banking Agency of the FBiH (Official Gazette of the FBiH, Nos. 9/96 and 27/98, 20/00, 45/00, 58/02, 13/03, 19/03, 47/06, 59/06 and 48/08)

- FBiH Banking Agency's By-laws, Regulations and Decisions, most notably

- Decision on Amendments to Decision on Uniform Method of Effective Interest Rate Accrual and Reporting on Loans and Deposits (24 June 2009)

- Decision on Temporary Renegotiation of Citizens' Credit Liabilities and Processing of Banks in the Federation of Bosnia and Herzegovina (02 June 2009, amended on 28 July 2009)

- Decision on Minimum Standards for Recording Bank's Loan Activities (19 December 2002)

- Law on Obligations (Official Gazette of the FBiH, Nos. 2/92, 13/93 and 13/94)

- Law on Inspections (Official Gazette of the FBiH, No. 69/05)

- Code of Administrative Procedure (Official Gazette of the FBiH, 2/98 48/99)

- Financial Collateral Law (Official Gazette of the FBiH, No.54/04)

\footnotetext{
${ }^{5}$ The authors did not visit Brcko District, BiH, and, thus, this Review does not deal in any way with legislative enactments or regulatory provisions specific to that District.
} 
- Law on the Execution of Criminal Sanctions (Law on Misdemeanors) (Official Gazette of the FBiH, No. 44/98 and 42/99 (HRD 12/09))

- Payment Transaction Law (Official Gazette of the FBiH, No. 32/00)

- Law on Bankruptcy Proceedings (Official Gazette of the FBiH, No. 29/03, 32/04 and 42/06)

- Ministry of Trade Circulars

\section{Republika Srpska Entity-level:}

- The Constitution of RS (Official Gazette of RS, No. 6/92, 8/92, 15/92, 19/92, 21/92, 28/94, 8/96, 13/96, 15/96, 16/96, 21/96, 36/00, 31/02, 31/03, 98/03, 117/05, and 48/11)

- Law on Banks (adopted on the Fifth Session of the National Assembly of Republika Srpska on April 29 and 30, 2003, Official Gazette of RS, No. 44/03, and 74/04)

- $\quad$ Law on the Banking Agency of the RS (Official Gazette of RS, No. 10/98, 16/00, 18/01, 71/02, 18/03 and 39/03)

- RS Banking Agency's By-laws, Regulations and Decisions, most notably:

- Decision on the Uniform Manner of Calculation, and Expression of Effective Interest Rate for Loans and Deposits (Official Gazette of RS, No. 3/07, 82/09, and 97/09)

- Decision on Minimum Standards for Documenting Bank's Lending Activities (10 February 2003) (Official Gazette of RS, No. 12/03)

- By-Laws (Official Gazette of RS, No. 38/98 and 67/04)

- Decision on Bank Supervision (Official Gazette of RS, No. 12/03)

- Decision on Regulating Minimum Standards for Credit Risk Management and Banks Asset Classification (10 February 2003, amended on 23 December 2005) (Official Gazette of RS, No. 12/03, 85/04, 01/06 and 136/10)

- Decision on Minimum Standards of Bank Activities related to Prevention of Money Laundering and Terrorism Financing (February 2003) (Official Gazette of RS, No. 12/03, 55/04 and 56/05)

- Decision on detailed Conditions and Procedures of Banks following Consumer Complaints (Official Gazette of RS, No. 58/10)

$\circ$ The Rulebook on the Banking System Ombudsman of the RS (Official Gazette of RS, No. 48/11)

○ The Rules of the RS Banking System Ombudsman's Treatment of Notification or Complaint by Financial Services' Users (Official Gazette of RS, No. 111/11)

- Law on the Default Interest Rate (Official Gazette RS, no. 19/01, and 52/06)Law on Obligations (Official Gazette of RS, Nos. 17/93, 3/96, 39/03 and 74/04)

- $\quad$ Law on Inspections (Official Gazette of RS, No. 74/10)

- Law on General Administrative Procedure (Official Gazette of RS, No. 13/02, 87/07 and 50/10)

- The Law on Minor Offences of the Republika Srpska (Official Gazette RS, no. 34/06, 1/09. And 109/11)

- Law on the Execution of Criminal Sanctions and Sanctions passed in Minor Offences Proceedings (Law on Misdemeanors) in RS (Official Gazette of RS, No. 64/01)

- Law on Payment Transactions (Official Gazette of RS, No. 12/01)

- Law on Bankruptcy Proceedings (Official Gazette of RS, No. 26/10 -consolidated text)

- Law on Coordination Committee for Supervision over the RS Financial Sector (Official Gazette of RS, No. 49/09)

- Law on Insurance Agencies(Official Gazette of RS, No 17/05, 1/06, and 64/06)

- Ministry of Trade and Tourism: circulars 


\section{Summary of Institutional Arrangements ${ }^{6}$}

Although there is no single government agency responsible for developing and enforcing consumer protection in banking or financial services, various agencies at State and Entity level deal with this subject. There is no single agency, whether at State or Entity level, that is responsible for informing citizens of their rights and interests as consumers, ensuring that these rights and interests are protected, and conducting market supervision in the field of consumer protection regarding banking and other financial services. Rather, various agencies at State and Entity level deal, however modestly or inappropriately, with the subject of consumer protection in banking services. These agencies are summarized below.

The Consumer Protection Council (the Consumer Council) is an administration organ established at State level by the Consumer Protection Act of 2005. The Consumer Council consists of 15 individuals representing the following institutions:

1. Ministry of Foreign Trade and Economic Relations, chairman;

2. Competition Council of $\mathrm{BiH}$;

3. Veterinary Office of $\mathrm{BiH}$;

4. Office for Phyto-Sanitary Protection of $\mathrm{BiH}$;

5. Statistics Agency of $\mathrm{BiH}$;

6. Institute for Standards of $\mathrm{BiH}$;

7. Institute for Measurements of $\mathrm{BiH}$;

8. Institute for Intellectual Property of $\mathrm{BiH}$;

9. Ministry of Trade of the FBiH;

10. Ministry of Trade and Tourism of the RS;

11. Competent body of Brčko District;

12. A FBiH consumers' organization;

13. A RS consumers' organization;

14. Union of BiH Consumer Associations (2 representatives). ${ }^{7}$

The Consumer Council has limited institutional capacity to focus on financial sector issues. By the terms of the Consumer Protection Act, the Consumer Council is required to meet at least four times a year. ${ }^{8}$ The Council operates without any permanent staff and, as its membership makes clear, it is not focused on issues of consumer protection in banking or in any other segment of the financial sector. Its purposes are to: (i) prepare an Annual Consumer Protection Program for adoption by the State's Council of Ministers; (ii) monitor the implementation of these annual Programs; (iii) determine the basics of

\footnotetext{
${ }^{6}$ This Review, likewise, does not deal with any Brčko District institution that may be concerned with any aspect of consumer protection in that District.

${ }^{7}$ See Article 106 (1) of the Consumer Protection Act.

${ }^{8} \mathrm{Ibid}$, Article 106 (2). The Council met four times in 2007 and three times in 2008. As of November 20, 2009, it had met only twice in 2009.
} 
consumer protection policies; and (iv) define the volume of activities to be financed or co-financed from the State budget. ${ }^{9}$

The Ombudsman Institution for Consumer Protection in $\mathrm{BiH}$ (Consumer Ombudsman) is an "independent institution" established by Article 100 of the Consumer Protection Act. The Consumer Ombudsman is appointed for a five-year term (renewable once) by the State-level Council of Ministers on the recommendation of the State Ministry of Foreign Trade and Economic Relations. The Office is located in Mostar, is financed exclusively by the State budget ${ }^{10}$ and has a full-time staff of four, including the Ombudsman and two assistant ombudsmen. ${ }^{11}$ The Office exists in order:

- to disseminate information on consumer rights and obligations and to support consumer associations in performing such activities;

- $\quad$ to review practices and proposed practices regarding business-to-consumer relationships;

- to investigate market practices aimed at consumers whether on his or her own initiative or following complaints and to coordinate in these respects with Entity and Brčko District Market Inspectorates;

- to make decisions or take appropriate action in cases of consumer complaints or business malpractices;

- to issue guidelines or recommendations about particular unfair standard terms or practices used in specific sectors or by specific economic operators;

- $\quad$ to recommend the use of particular contractual terms;

- to negotiate, with representatives of concerned trade associations, model contracts applicable to specific sectors of activity;

- to propose and initiate the settlement of consumer disputes through alternative dispute resolution mechanisms;

- $\quad$ to liaise with the Human Rights Ombudsman Institution on common concerns;

- to advise the Consumer Protection Council and the State Level Council of Ministers on necessary improvements in consumer law and on the direction and effectiveness of Government policy in the consumer area; and

- $\quad$ to assess the impact of other governmental initiatives on consumer protection. ${ }^{12}$

An appeal against a decision of the Consumer Ombudsman may be made, but only in the event that the Consumer Protection Act or some other legislative enactment expressly allows this possibility. While covering all aspects of consumer protection, the Consumer Ombudsman ventured into the territory of consumer protection in banking services on 28 April 2009 when it issued 16 "Guidelines and Recommendations in the Sector of Consumer Loans".

The Competition Council is an independent State-level council, established by the Law on Competition of 2005. This law is modeled on European Union (EU) competition laws and addresses non-competitive conditions in $\mathrm{BiH}$. The law defines monopolistic conditions and prohibits abuse of "dominant positions" by monopolies. It also contributes to general consumer protection in $\mathrm{BiH}$ by establishing a mechanism for the redress of individuals' grievances against monopolies and by levying appropriate penalties. It does not, however, specifically address consumer protection issues in banking.

The State-level Market Surveillance Agency ${ }^{13}$ coordinates overall activities of market surveillance in BiH, leaving to Inspection Authorities in RS and the FBiH ("Inspectorates") to carry out direct inspection controls, including on-site inspections.

\footnotetext{
${ }^{9}$ Ibid, Article 107

${ }^{10}$ The annual budget for 2009 amounts to KM 400,000.

${ }^{11}$ The Ombudsman and the two assistant ombudsmen come from the three distinct ethnicities in BiH and operate by consensus.

12 See Article 101 of the Consumer Protection Act.
} 
The State-level Central Bank of Bosnia and Herzegovina (CBBiH) was established in June 1997, with the goal of achieving and maintaining monetary stability. ${ }^{14}$ In addition, basic tasks of the Central Bank include coordinating the activities of the Banking Agencies at Entity-level, including the holding of monthly meetings of the heads of the Banking Agencies with representatives of the Central Bank and the receiving of monthly reports from the Banking Agencies on their activities and on developments at the financial institutions under their jurisdiction. ${ }^{15}$ That said, while the Central Bank is one of the most highly respected institutions in $\mathrm{BiH}$ and has undoubted convening power when matters affecting the banking system of $\mathrm{BiH}$ are in question, it does not play a supervisory role in respect of the operations of $\mathrm{BiH}$ commercial banks. However, in 2008 the $\mathrm{CBBiH}$ and the Banking Agencies signed the Memorandum on the Principles of Coordination of Banking Supervision, Cooperation, Exchange of Data and Information, which intensified the cooperation and coordination between these institutions. It is expected that, under the framework of the recent Law on the RS Banking Agency that expanded its mandate to include consumer protection responsibilities, the RS Banking Agency will coordinate with $\mathrm{CBBiH}$ further in this area.

The Central Bank set up the Central Registry of Credits of Legal and Physical Entities in 2006 to collect and access credit information of legal entities initially, and natural persons later. The scope of information collected and accessed through the Central Registry of Credits has been constantly evolving. In January 2009, the Central Bank issued a Decision that established access to the Registry for commercial banks, micro-credit organizations and savings-credit organizations, as well as to any leasing company, insurance organization or other entity that seeks to be included in the Registry.

The Personal Data Protection Agency was set up in 2009 as an independent authority in charge of overseeing the Law on the Protection of Personal Data and related legislation, both at State and Entity level. The Agency replaced the Committee of Personal Data Protection, operating since 2001. The institutional change responded to the need for increased autonomy in this field and for compliance with the observations raised on this issue by the EU. The Agency is planning to conduct monitoring activities over all types of institutions handling personal data, including banks and other financial institutions. The Agency has started to review the data systems of banks that have requested the Agency's opinion.

The Deposit Insurance Agency of $\mathrm{BiH}$ was set up in 2002 as an independent, non-profit legal entity with full authority under the law of the State. The Agency has its headquarters in Banja Luka and branches in Sarajevo and Banja Luka. Twenty-five banks are members of the deposit insurance scheme. The main tasks of the Deposit Insurance Agency are to: (i) provide for protection of deposits of natural persons in member banks in accordance with the Law on Deposit Insurance; (ii) issue the deposit insurance membership certificate to any bank that meets the criteria for participation in the deposit insurance scheme (regarding capital, liquidity, asset quality, management, profitability, accounting standards and reserves); (iii) suspend or terminate membership; (iv) invest the capital of the Deposit Insurance Fund in line with provisions of the law and regulations of the Agency; (v) pay out insured deposits in case of cessation of a member bank's operations; and (vi) issue relevant regulations for the scheme and the Agency.

In both Entities, Banking Agencies license banks and other financial institutions, and are in charge of the prudential supervision of their activities. The Banking Agencies have the authority to impose penalties upon commercial banks and their officials if regulatory requirements are violated.

\footnotetext{
${ }^{13}$ Established by the Law on Market Surveillance (Official Gazette of BiH No. 45/2004).

${ }^{14}$ See Article 2, Section 1 of the Law on the Central Bank of BiH (Official Gazette of BiH, No. 1, 1997), as amended.

${ }^{15}$ Ibid., Article 2, Section 3. e
} 
Also in both Entities, Departments of the Ministries of Trade ${ }^{16}$ have set up Consumer Protection Offices. These offices provide budgetary resources to non-governmental consumer organizations or consumer associations.

Apart from government agencies, various associations play more or less significant roles in consumer protection in banking.

The Bosnia and Herzegovina Banks' Association has jurisdiction over the entire territory of BiH. This Association is non-governmental, non-political and not-for-profit ${ }^{17}$ and it resulted from the merger in 2004 of two pre-existing Associations of Commercial Banks, one in RS and the other in the FBiH. The Association's membership is voluntary and consists of 28 commercial banks operating in $\mathrm{BiH}$ as of November 2009. ${ }^{18}$ The Association is based in Sarajevo and has a full-time staff of three. Among other things, it has developed a voluntary Code of Conduct for all commercial banks. It has also established various Commissions, one of which is focused on legislative reform.

There are various consumer organizations or consumer clubs at State and Entity levels. Many of these receive modest sums from Government budgets to assist them in carrying out their work of helping consumers understand their rights and of acting on behalf of consumers when disputes arise in respect of their claims. There is an Association of Consumer Organizations in each Entity and a Union of Consumer Associations in $\mathrm{BiH}$.

\footnotetext{
${ }^{16}$ In RS, the relevant Ministry is the Ministry of Trade and Tourism.

${ }^{17}$ See the Articles of Association of the Banks' Association of BiH dated 24 J une 2004.

${ }^{18}$ The RS Development Bank has not joined and has no intention of joining since it does not take deposits, but rather acts as an economic development arm of the RS.
} 


\section{Key Recommendations}

- Consideration needs to be given to making amendments to the existing State-level Consumer Protection Act, taking into consideration the 2008 EU Directive on Consumer Credit and including detailed cross-references to all relevant provisions in the Law on Obligations.

- As required by the State Law on Consumer Protection of 2005, the Entities should take steps to legislate in the field of consumer protection, provided, however, that this legislation is in harmony with the State law.

- Consideration needs to be given to strengthening the institutional framework for banking consumer protection.

- The Banks' Association should be encouraged to draft a revised and updated Code of Ethics for formal endorsement by all member banks.

- Consideration might also be given to establishing a principles-based, statutory code of conduct for banks that is devised by a team under the supervision of a Central Bank Commission. Once enacted, this would then need to be strictly monitored by the Banking Agencies to ensure compliance with the law.

- When making a recommendation to a consumer, any BiH commercial bank should be required, by law, to gather, file and record sufficient information from the consumer in order to ensure that its recommended product or service is appropriate to that consumer.

- Suitability rules must be enacted and enforced.

- Consideration should be given to requiring any bank to conduct specific actions prior to having a consumer enter into a consumer credit agreement with the bank.

- Given the extent of public concern still surrounding the questions of how, when and why floating interest rates may legitimately be adjusted, it is suggested that a Central Bank Commission, in technical discussions, look to these issues as a matter of some urgency so that better guidance can be forthcoming from both Banking Agencies as soon as possible.

- A "cooling-off period" should be applied to all consumer loans.

- The law should explicitly indicate the cases where bundling of a product or service is permissible. The law should also require full disclosure in the event that any accompanying service is offered to a consumer in the context a consumer credit.

- The revised banking code of ethics should state that a bank shall be prevented from excluding or restricting, or from seeking to exclude or restrict, any liability arising from the bank's failure to exercise a duty of skill, care and diligence.

- Every bank should be required to provide a consumer, before he or she opens a bank account, with a written copy of its general terms and conditions and the specific terms and conditions that apply to the type of bank account to be opened.

- The Banks' Association should produce a standard set of easily understandable scenarios reflecting variation of conditions of a credit agreement (e.g. increase of interest rate or foreign exchange rate), which should be given to consumers prior to signing specific types of credit agreements.

- Banks should be required to provide the consumer with a Key Facts Statement for each product or service offered.

- The Banks' Association, possibly with the collaboration of the Banking Agencies, should establish and administer minimum competency requirements for bank staff who deal with consumers, prepare Key Facts Statements or advertisement materials, or market the bank's services and products. 
- Consideration should be given to developing a law on debt collection operations.

- There should be regulations covering disclosure of personal information to government authorities.

- There should be a specific legal framework that regulates the operation of the public credit registry as well as all private credit bureaus.

- Banks should be required to establish an internal procedure to handle consumer complaints.

- There should be a dispute resolution mechanism either at State or Entity level with jurisdiction over all types of consumer-related banking services disputes. A Central Bank Commission should establish a working group to evaluate the most viable institutional arrangement in $\mathrm{BiH}$.

- A national program on financial education should be developed, including mechanisms to implement financial education initiatives in schools.

- Consumer awareness of financial issues should be improved through actions from government authorities and consumer NGOs.

- Consumer associations need to be strengthened, with larger and more stable sources of funding and better institutional capacity, in order to play a more salient role in respect of consumer protection issues.

- A national survey of financial literacy should be conducted as a first step in the development of a national program of financial education.

- The Banking Agencies and the Competition Council should be required, by law, to consult regularly with one another so as to ensure the establishment, application and enforcement of consistent policies regarding banking regulation and market competition. 


\section{Good Practices: Banking Sector}

\begin{tabular}{|c|c|}
\hline SECTION A & CONSUMER PROTECTION INSTITUTIONS \\
\hline $\begin{array}{l}\text { Good Practice } \\
\text { A. } 1\end{array}$ & $\begin{array}{l}\text { Consumer Protection Regime } \\
\text { The law should provide for clear consumer protection rules regarding any } \\
\text { banking product or service, and all institutional arrangements should be } \\
\text { in place to ensure the thorough, objective, timely and fair } \\
\text { implementation and enforcement of all such rules. } \\
\text { a. Specific statutory provisions need to create an effective regime for } \\
\text { the protection of any consumer of a banking product or service. } \\
\text { b. Either a general consumer agency or a specialized agency should } \\
\text { be responsible for implementing, overseeing and enforcing } \\
\text { consumer protection, as well as collecting and analyzing data } \\
\text { (including complaints, disputes and inquiries). } \\
\text { c. The law should provide and not prohibit a role for the private } \\
\text { sector, including voluntary consumer protection organizations and } \\
\text { self-regulatory organizations, regarding consumer protection in } \\
\text { general and in banking products and services in particular. }\end{array}$ \\
\hline Description & $\begin{array}{l}\text { The only consumer protection rules, as such, in BiH are contained in the State-level } \\
\text { Consumer Protection Act of } 2005 \text {. Although not stated in this Act, the apparent power of } \\
\text { the State to legislate in this field comes from the Constitutional responsibilities of "the } \\
\text { Institutions" of BiH in respect of foreign trade. }{ }^{19} \text { Unlike the case of RS which provides in its } \\
\text { Constitution that "the Republic shall ensure consumers protection"20, there is no such } \\
\text { provision in either the Constitution of BIH or the Constitution of the FBiH. } \\
\text { The Consumer Protection Act "governs the relations between consumers ... and traders in } \\
\text { the territory of Bosnia and Herzegovina."121 As is true in the EU and elsewhere, a "consumer" } \\
\text { is defined as "any natural person who buys, acquires or uses products or services for his or } \\
\text { her personal needs or for the needs of his or her household." "22 And, the term "trader" is } \\
\text { defined as "any person }{ }^{23} \text { who directly or acting as intermediary of other persons supplies } \\
\text { products or services to the consumer."24 "Product" means "any thing being the result of } \\
\text { human activity that is intended for consumers ... (and) supplied ... in the course of a } \\
\text { commercial activity."125 And, "service" means "any activity intended to be offered to } \\
\text { consumers."26 Thus, being broadly focused on all manner of commercial products and } \\
\text { services, the Act clearly covers the protection of any consumer who is offered or supplied } \\
\text { any product or service by a commercial bank. } \\
\text { With the exception of Chapters } 11 \text { and } 16 \text { of the Consumer Protection Act dealing with } \\
\text { "consumer credit", however, there is no specific reference in this Act to any banking product } \\
\text { or service. Concerns exist, though, regarding the definition of "consumer credit agreements" }\end{array}$ \\
\hline
\end{tabular}

\footnotetext{
${ }^{19}$ See Paragraph 1 (b) of Article III of the Constitution of BiH. Support for this proposition comes from the fact that the Ministry of Foreign Trade and Economic Relations is the only Ministry named to lead efforts regarding consumer protection at State-level and both Entities have chosen to follow suit by having respective Departments in their Ministries of Trade (in RS it is the Ministry of Trade and Tourism) deal at least with certain aspects of consumer protection as they relate to registering, contracting and providing modest stipends to consumer associations.

${ }^{20}$ See Article 53 of the RS Constitution

${ }^{21}$ Article 1 (1) of the Consumer Protection Act

22 Ibid, Article 1 (3)

${ }^{23}$ By the law of $\mathrm{BiH}$, the term "person" means either a legal or natural person.

${ }^{24}$ See Article 1 (5) of the Consumer Protection Act

${ }^{25}$ I bid, Article 1 (7)

${ }^{26}$ Ibid, Article 1 (10)
} 


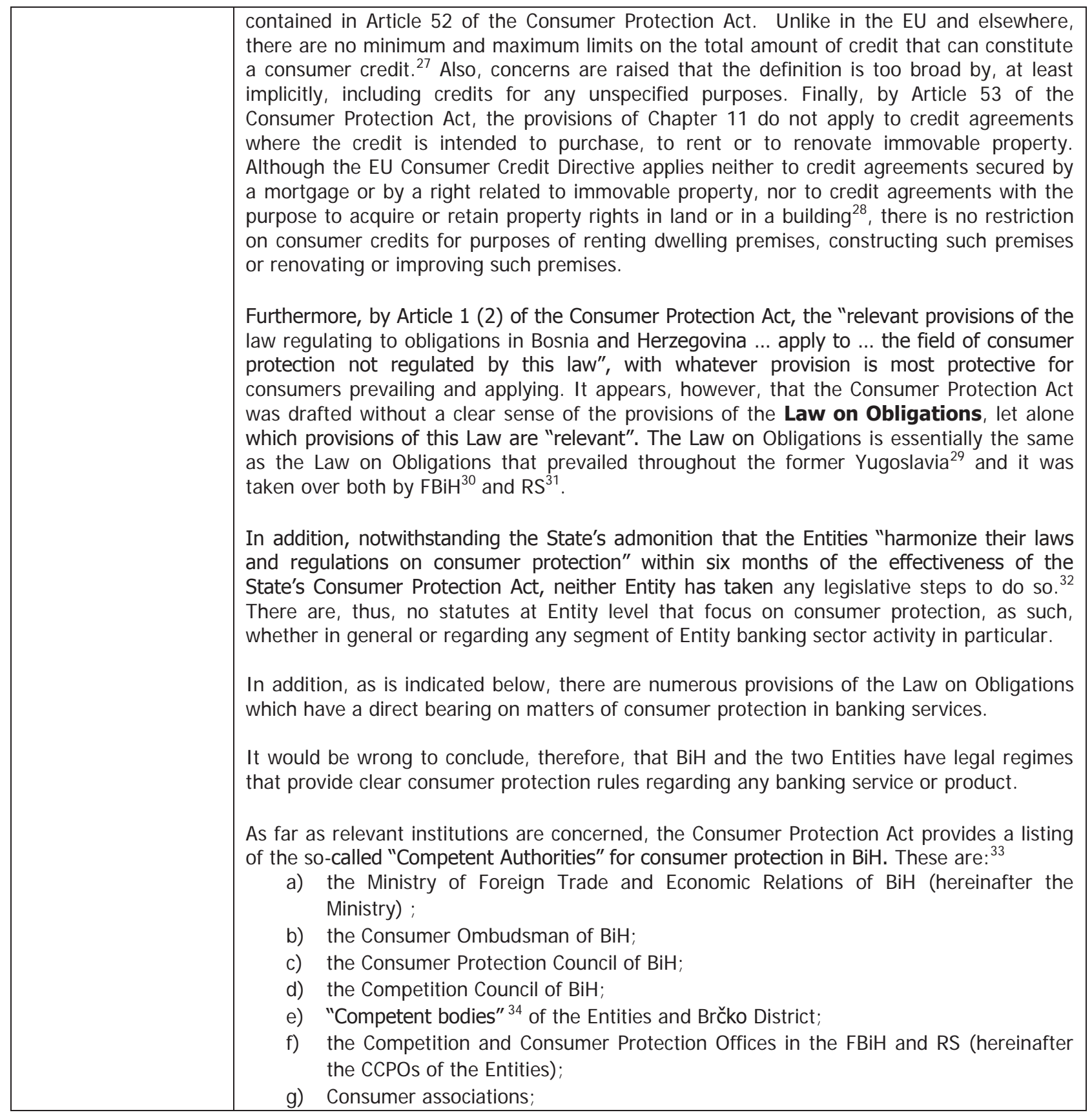

\footnotetext{
${ }^{27}$ By Article 2, 2 c) of the Consumer Credit Directive 2008 of the EU, that Directive does not apply to credit agreements involving a total amount of credit less than 200 Euros or more than 75,000 Euros.

${ }^{28}$ EU Consumer Credit Directive 2008, Article 2, 2 a) and b)

${ }^{29}$ This Law on Obligations deals with such important principles as the autonomy of will, the equality of parties in contractual relations, obligations resulting from contracts, and the prohibition of abuse of rights,. They also regulate issues relevant for the comprehensive and timely consideration of risks that may have an impact on the economic well-being of contractual parties whether during the stage of negotiation, the phase of contract conclusion or the execution of the contractual terms. Other issues in these laws dealing with contract interpretation, usury, credit, surety, deposit, business operations with securities, the making of offers, and substantial deceits, among other matters, are also of relevance to consumer protection.

${ }^{34}$ The Law neither indicates what these bodies are, nor what authority decides which ones they are.
} 


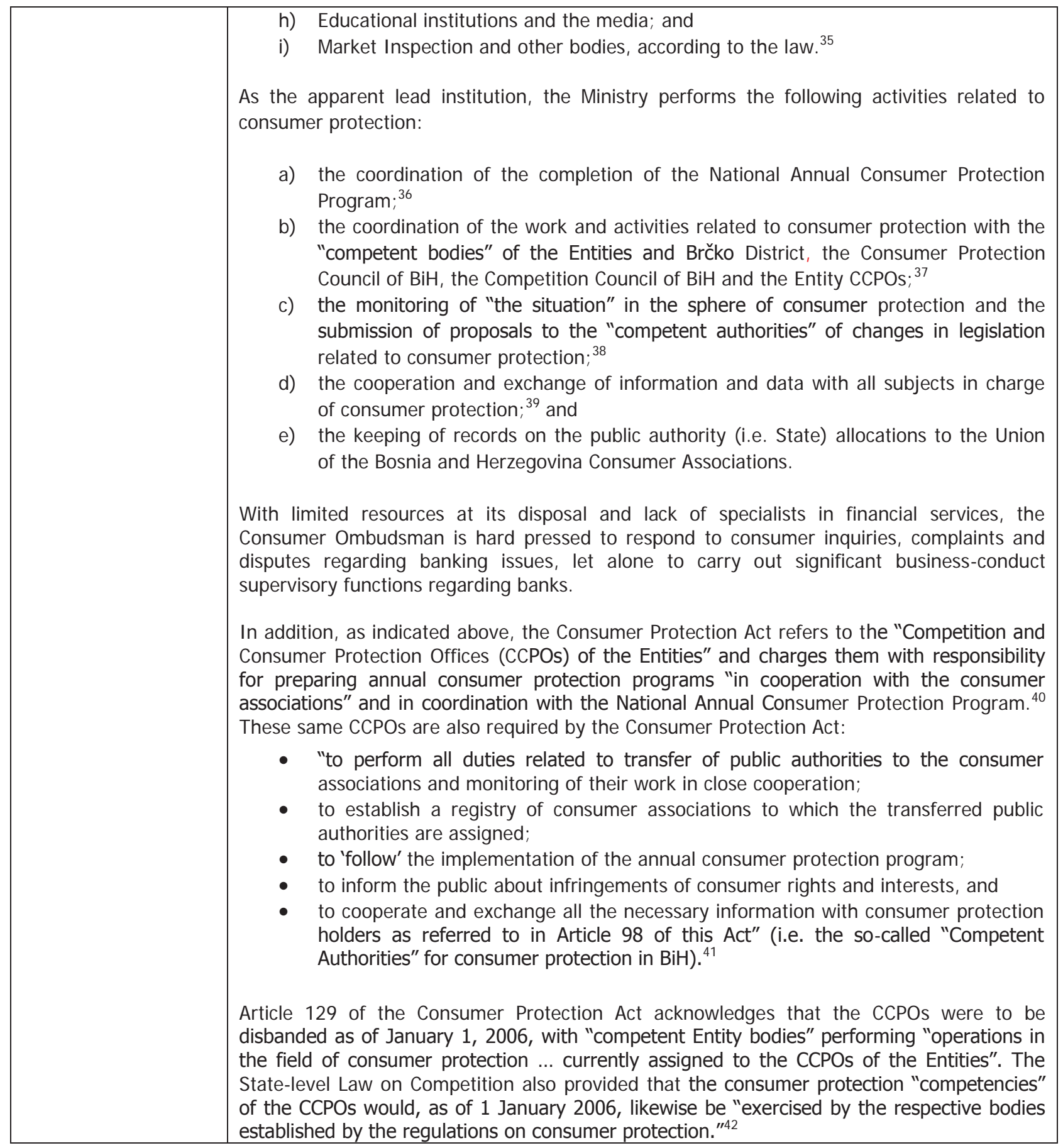

${ }^{35}$ It is unclear what "other bodies" consist of and whether "the law" in this instance is that of the State, the Entities or all three.

${ }^{36}$ The 2009 Annual Program has some 100 items deserving of attention, none of which focus on the delivery of banking products and services, as such

${ }^{37} \mathrm{Few}$, if any, examples of such coordination exist, at least in respect of consumer protection in banking services.

${ }^{38}$ It is unclear how this monitoring role is carried out on a practical basis with any regularity. And, there is no evidence that the Ministry has ever monitored the situation in the sphere of consumer protection in banking products and service. Nor has it ever submitted proposals to the "competent authorities" of changes in legislation related to consumer protection generally and related

${ }^{39}$ Again, it is unclear how the Ministry's role of coordination and exchange of information is carried out on a practical, daily basis. Furthermore, there have been few, if any, examples of exchanges regarding consumer protection in banking services.

${ }^{40}$ See Article 110 (1) of the Consumer Protection Act

41 Ibid, Article 110 (2)

${ }^{42}$ See Article 57 (3) of the Act on Competition 
With the exception of Entity regulations dealing with the assignment of certain Entity projects and programs to consumer associations and the highly modest financing from the Entity budget of such associations as are registered within respective Departments of the Entity Ministries of Trade, there still are no regulations on consumer protection in either Entity that establish such "respective bodies" in any robust fashion.

Entity-level Laws on Banking Agency, adopted in 1996, established the Banking Agency of the Federation of Bosnia and Herzegovina and the Banking Agency of the Republika Srpska. The Banking Agencies are the principal banking regulators in their respective territories and oversee and regulate the banking industry. They are independent institutions of the respective Entities' governments.

The FBiH and RS Laws on Banking Agency are virtually identical ${ }^{43}$ and the Banking Agencies' activities in respect of commercial banks (as defined in the respective Laws on Banking Agency) fit broadly within the following categories:

- $\quad$ Regulation: Issuing licenses for banks; approving banks' managing staff; monitoring banks' operations; revoking banks' licenses in case of violations of relevant law; monitoring changes to the capital and/or organizational structure of banks; supervision of banks' restructuring or bankruptcy proceedings.

- Enforcement: Imposing appropriate punitive measures in case of violations of banking laws or regulations. ${ }^{44}$

- Legislation: Drafting and adopting by-laws and decisions relevant to the Law on Banking Agency, Law on Banks and other laws under the Banking Agencies' jurisdiction.

Each Entity, likewise, has its own Law on Banks which provides the fundamental framework for banking regulation and was passed in similar form in the $\mathrm{FBiH}$ in 2000 and the RS in 2003. These laws provide more details than the Laws on Banking Agency regarding the supervision of banks in each entity. Included in these laws are requirements regarding banks' ownership structures, corporate governance arrangements and reporting requirements, as well as the consequences to banks of legal infractions.

Although, given the general ambit of its provisions, it is perhaps not surprising that the Consumer Protection Act makes no mention of the Banking Agencies, no government authorities are more competent at Entity-level when it comes to matters of consumer protection in banking services.

A description of the government institutions and NGOs having any relevance to consumer protection in banking is provided in the Summary of Institutional Arrangements above. To date, however, there has been minimal cooperation and coordination between these various stakeholders to advance consumer protection in any realm, including that of banking products and services.

In summary, neither at State-level nor at Entity-level is there any general consumer protection agency or any specialized consumer protection agency dealing with banking products and services responsible for implementing, overseeing and enforcing consumer protection, as well as collecting and analyzing data (including complaints, disputes and inquiries).

Although making no reference to the private sector, as such, nor to any self-regulatory organization, the Consumer Protection Act does provide a role for voluntary consumer associations regarding consumer protection at least in general, if not to banking products

\footnotetext{
${ }^{43}$ The RS Law on Banking Agency, however, does not explicitly mention the micro-credit sector, whereas the FBiH Law on Banking Agency does specifically refer to the micro-credit sector and its oversight.

${ }^{44}$ These violations include those related to anti-terrorism funding statutes and/or any activity which may be "obstructive of the peace implementation process as pursued under the aegis of the General Framework Agreement for Peace in Bosnia and Herzegovina."
} 


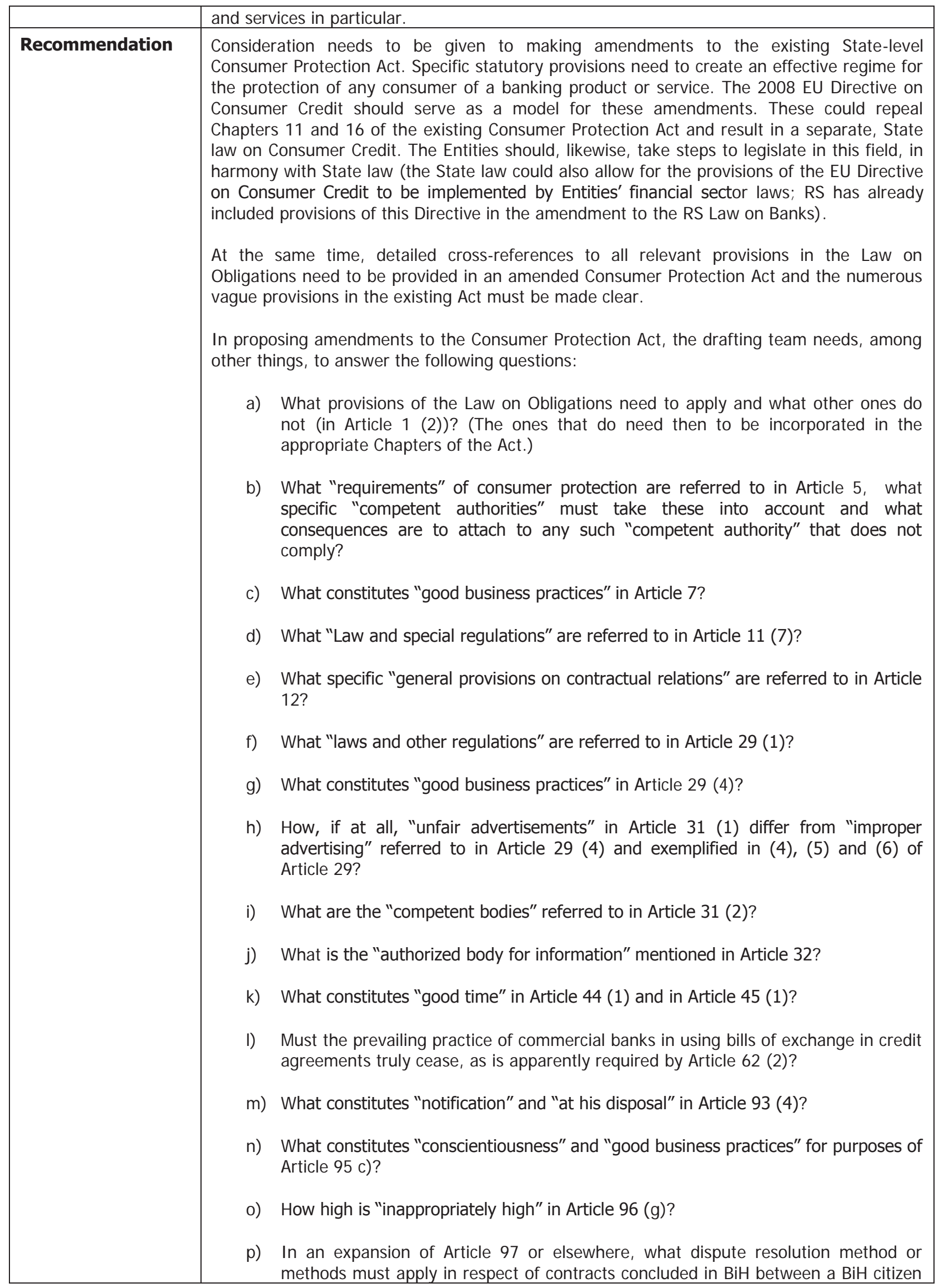




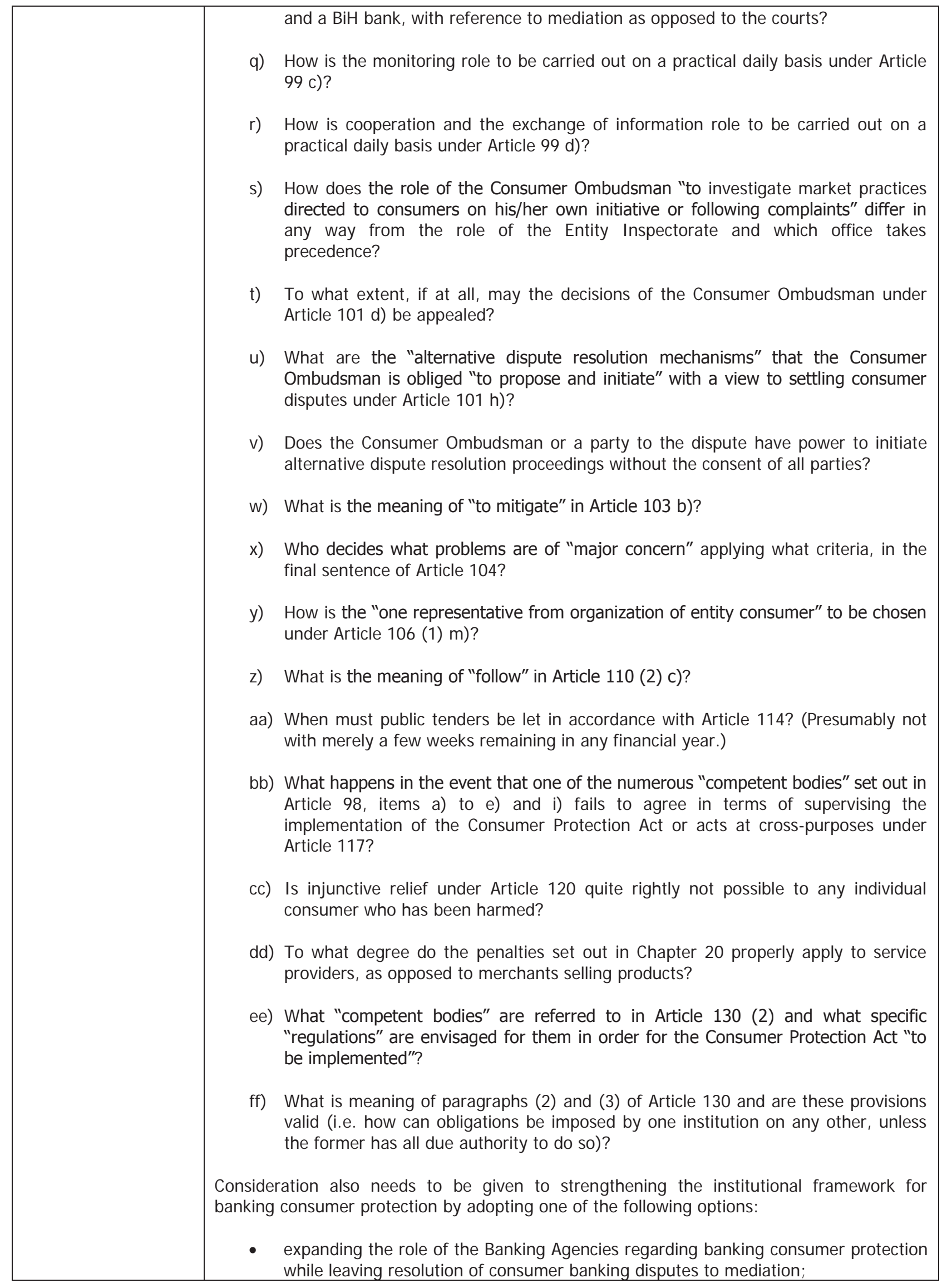




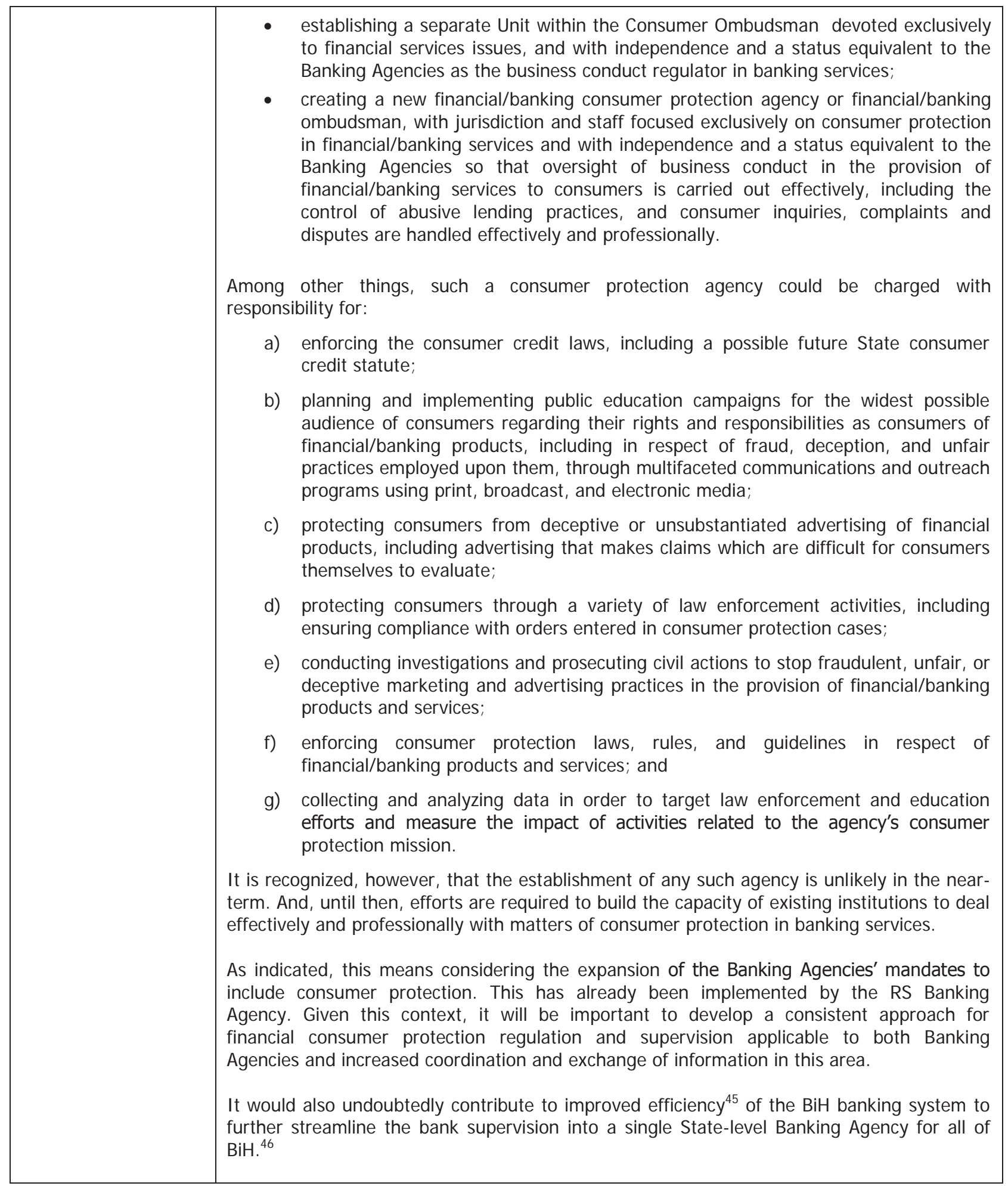

\footnotetext{
${ }^{45}$ The Decisions, Directives and practices of the Banking Agencies in both Entities are closely harmonized in those instances where they are not the same. The duplication of scarce talent required to supervise the same commercial banks throughout BiH is costly and the requirement that these banks have to report to two rather than one supervisor inevitably results in inefficiencies in supervisory terms, as well as in terms of the duplication of the reporting responsibilities of the commercial banks.

${ }^{46}$ But see Article 68. of the Constitution of the Republika Srpska, which makes it responsible for regulating the banking system within its territorial borders.
} 


\begin{tabular}{|c|c|}
\hline & $\begin{array}{l}\text { Consideration should also be given to: } \\
\text { b) improving the legal framework for dispute resolution }{ }^{47} \text { and drafting a law on debt } \\
\text { collection, as well as other matters referred to in separate sections below; } \\
\text { c) funding all agencies dealing with financial/banking consumer protection, }{ }^{48} \text { at least in } \\
\text { significant part, from the financial/banking services industry so that qualified banking, } \\
\text { legal and other professionals can be employed; } \\
\text { d) requiring all relevant institutions, including the Consumer Ombudsman, the Banks } \\
\text { Association, the Banking Agencies, the Entity-level Inspectorates and any relevant } \\
\text { consumer NGOs to meet regularly in an effective consultative council, under the } \\
\text { chairmanship of the Central Bank (hereinafter called the Central Bank Commission), in } \\
\text { order to address and solve issues of consumer protection in banking services in a } \\
\text { coordinated fashion; } \\
\text { e) improving the transparency, availability and quality of data of relevance to consumer } \\
\text { protection in banking services, }{ }^{49} \text { including consumer complaints and their treatment, } \\
\text { as well as relevant recommendations made, and decisions taken, by the Consumer } \\
\text { Ombudsman, the Banks' Association, the Banking Agencies, Entity-level Inspectorates } \\
\text { and any other relevant institutions, including the courts; and } \\
\text { f) seeking additional funding for the NGO community. }{ }^{50}\end{array}$ \\
\hline Good Practice A. 2 & $\begin{array}{l}\text { Codes of Conduct for Banks } \\
\text { a. There should be a principles-based, statutory code of conduct for banks } \\
\text { that is devised in consultation with the banking industry and if possible } \\
\text { with consumer protection associations, and is monitored by a statutory } \\
\text { agency or an effective self-regulatory agency. } \\
\text { b. Every bank, acting alone and together, should publicize and disseminate } \\
\text { this statutory code of conduct to the general public through appropriate } \\
\text { means. } \\
\text { c. The statutory code should be augmented by voluntary codes of conduct } \\
\text { for banks on such matters as facilitating the easy switching of consumers' } \\
\text { current accounts and establishing a common terminology in the banking } \\
\text { industry for the description of banks' charges, services and products. }\end{array}$ \\
\hline Description & $\begin{array}{l}\text { There is no statutory code of conduct for BiH banks. Nor is there any statute or regulation at } \\
\text { State- or Entity-level providing that in order to promote the protection of consumer rights } \\
\text { and the observance of the law, banks and the Banks' Association may develop and } \\
\text { implement the enforcement of a "good practice code". } \\
\text { The Banks' Association has, however, promulgated a so-called voluntary "Code of Ethics"51 } \\
\text { (hereinafter the Code) which has been endorsed by all member-banks. Its avowed purposes } \\
\text { are: (i) to set forth standards of good behavior and open communications between } \\
\text { customers and banks; (ii) to raise the image of banking in society; and (iii) to promote } \\
\text { responsibility, transparency and professional conduct in the BiH banking industry. The Code } \\
\text { expressly took effect as of } 13 \text { December } 2005 \text { and the Banks' Association members were } \\
\text { required to comply with its provisions as of } 31 \text { December } 2006 .^{52} \text { It has, however, never } \\
\text { been monitored by the Banking Agencies or any other statutory agency and it is not at all } \\
\text { clear to what extent the Banks' Association, itself, can properly be termed "an effective self- } \\
\text { regulatory agency". }{ }^{53}\end{array}$ \\
\hline
\end{tabular}

\footnotetext{
${ }^{47}$ For a discussion of Formal Dispute Settlement Mechanisms, see Good Practice E. 2 below.

${ }^{48}$ This means increasing allocations in the 2010 National Consumer Protection Program and subsequently, as well as obtaining important additional funding from the banking industry, as well as the EU and other donors.

${ }^{49}$ Ibid.

50 Ibid.

${ }^{51}$ See: www.ubbih.ba for the text of the Code on the Banks' Association website.

${ }^{52}$ See Paragraph 1 of Part III of the Code dealing with Transitional and Final Provisions.

${ }^{53}$ To date, there have been no cases brought before the Court of Honor of the Banks' Association and no disciplinary action taken, however mild, in respect of any bank that may have failed to apply any one or more provisions of the existing Code, notwithstanding the fact that by accepting the Code, a bank agrees to apply the Code's practices as "the minimum".
} 
The Code is expressly meant to standardize relationships between a bank and its customers (legal entities and consumers), as well as with other banks. But, since it is clearly an extension to the laws, regulations and instructions imposed by the Banking Agencies and other authorized bodies in place, it is, therefore, for each bank to adopt and apply as it sees fit. That said, there are at least potential consequences if, once endorsed by a bank, the bank fails to abide by it.

Special rules in the Code govern the relationship of a bank with a consumer. These require a bank, among other things, to:

- enable its staff to be aware of products and services offered by the bank;

- ensure that its staff offer products or service that best correspond with the concrete needs of individual consumers;

- apply standardized terminology with generally accepted meaning, so that any consumer can compare similar products or services offered by different banks;

- provide any consumer accurate and useful information related to the characteristics of products or services on offer, as well as to the terms, tariffs and decisions applied;

- request all relevant information about the customer and his or her needs and financial limits, depending on the product or service the consumer request;

- ensure that there are no vague terms in its business policy documents, application forms and access contracts, which would impose undefined commitments on consumers thereby bringing uncertainty to the consumer regarding his or her rights and obligations;

- act efficiently and with due attention when fulfilling commitments towards its consumers;

- to train its staff to comply strictly with the rules of banking secrecy and, in general, to act with full discretion in their contacts with consumers;

- employ its best efforts to avoid conflict of interests and, in any situation in which a conflict is inevitable, to enable equal treatment to all consumers;

- to treat all data regarding a consumer as a business secret, even if he or she no longer has the status of a customer;

- ensure that all personal data about a consumer's accounts is not revealed without the direct request of the consumer or with his or her explicit approval, except in cases clearly stated in the law;

- have reliable customer identification, in order to protect customers, for individual transactions, including personal and account data disclosure;

- employ data about a consumer and his or her accounts only for the purpose of enabling effective management of the consumer's account, as well as other services provided to consumer;

- $\quad$ permit a consumer the right to have access to his or her data in order to check on its accuracy and, potentially, to correct any incorrect facts.

- prevent unauthorized access to the bank's information and data systems so as to protect consumers' interests (as well as those of the bank);

- try to correct any error within reasonable period of time and without delay, in the event a consumer informs the bank of an error in the way the bank is operating; and

- show readiness to discuss with the consumer the issue of the consumer's financial difficulties in an effort to find a mutually acceptable arrangement, in the event the consumer informs the bank as soon as possible about any such financial difficulties.

By the terms of the subsequent chapter of the Code dealing with banking information and marketing, each bank is required to:

a) exchange accurate and timely information between it and its customers, so as to 


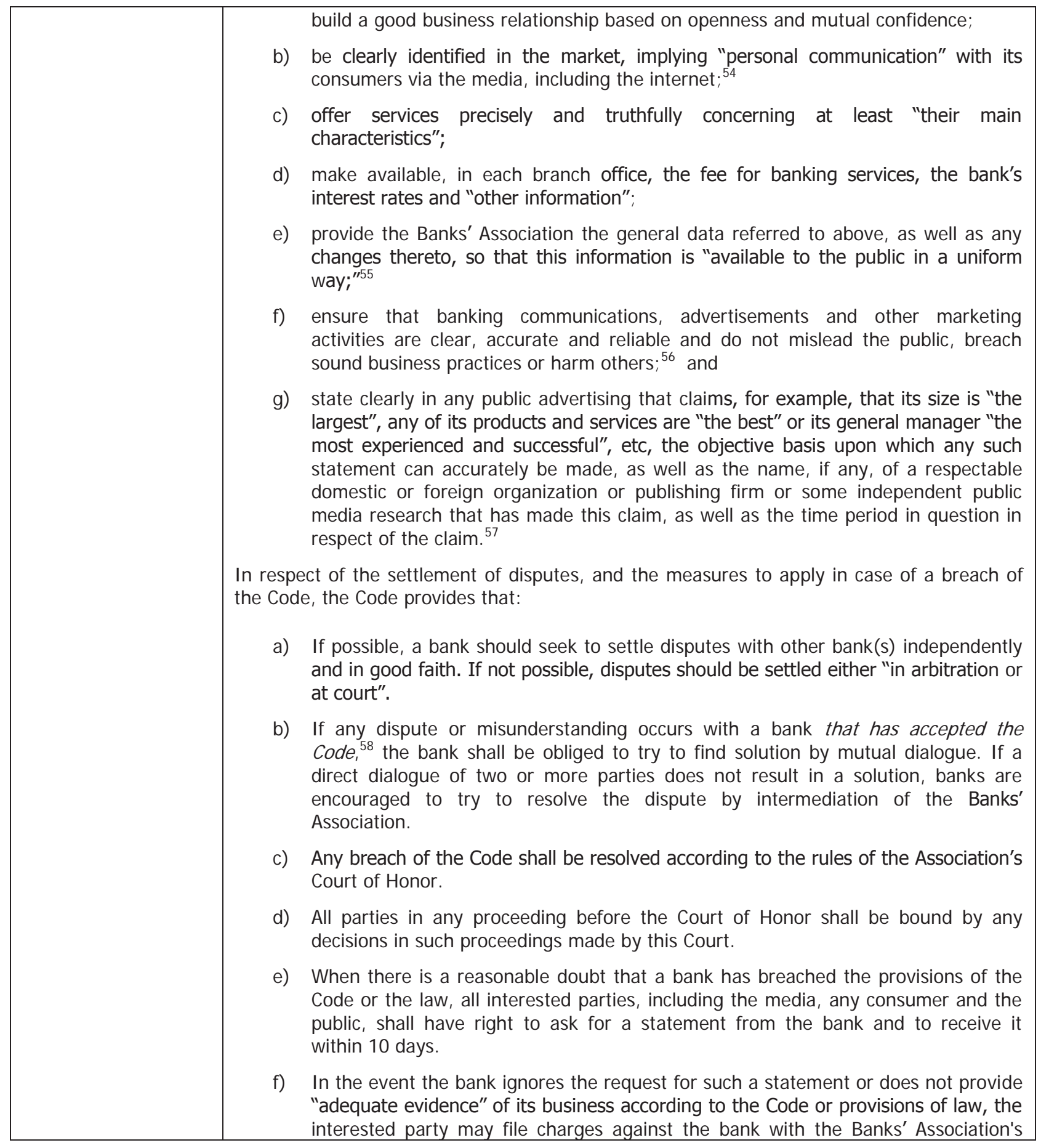

\footnotetext{
${ }^{54}$ According to the Communications Regulatory Agency of Bosnia and Herzegovina, the estimated internet usage rate in 2008 was $34 \%$ of the population, a significant increase relative to 2007 (27\%). In terms of internet subscribers, $20 \%$ were from Sarajevo and $16 \%$ from Banja Luka.

${ }^{55}$ It is unclear how this information is to be made readily available except by means of the Banks' Association's website.

${ }^{56}$ In these respects, the Code encroaches on and to some extent duplicates the legal requirements set out in Article 29 of the Consumer Protection Act

${ }^{57}$ Compare Article 30 of the Consumer Protection Act.

${ }^{58}$ The words in italics here clearly imply that a bank must take some independent action of its own in positively endorsing the Code before the bank can be taken to have accepted the Code. No such action has, however, been taken to date by any bank.
} 


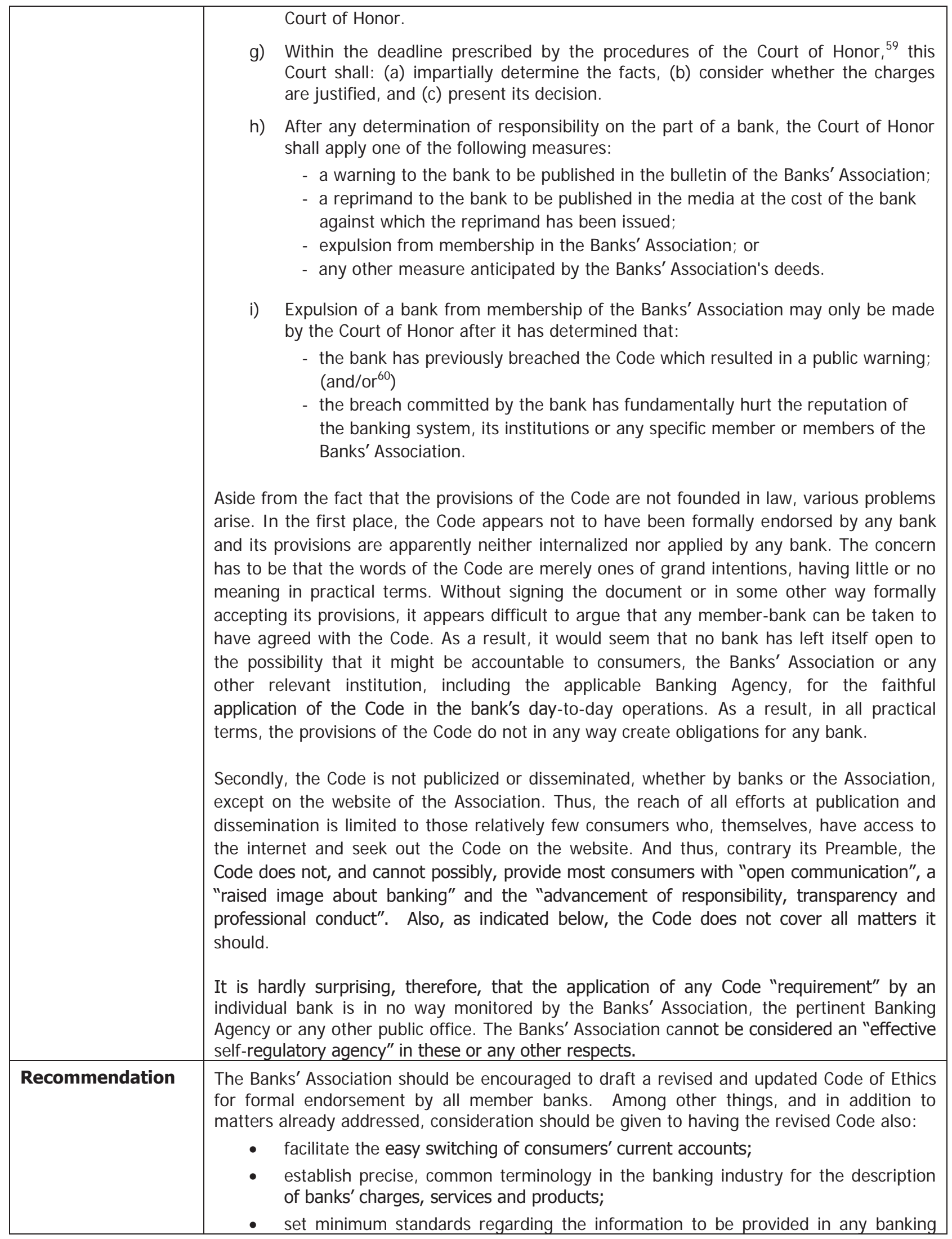

\footnotetext{
${ }^{59}$ See the Rules of Procedure for the Banks' Association's Court of Honor, dated 17 February 2006.

${ }^{60}$ It is unclear from the text whether "and" or "or" is the correct word here.
} 


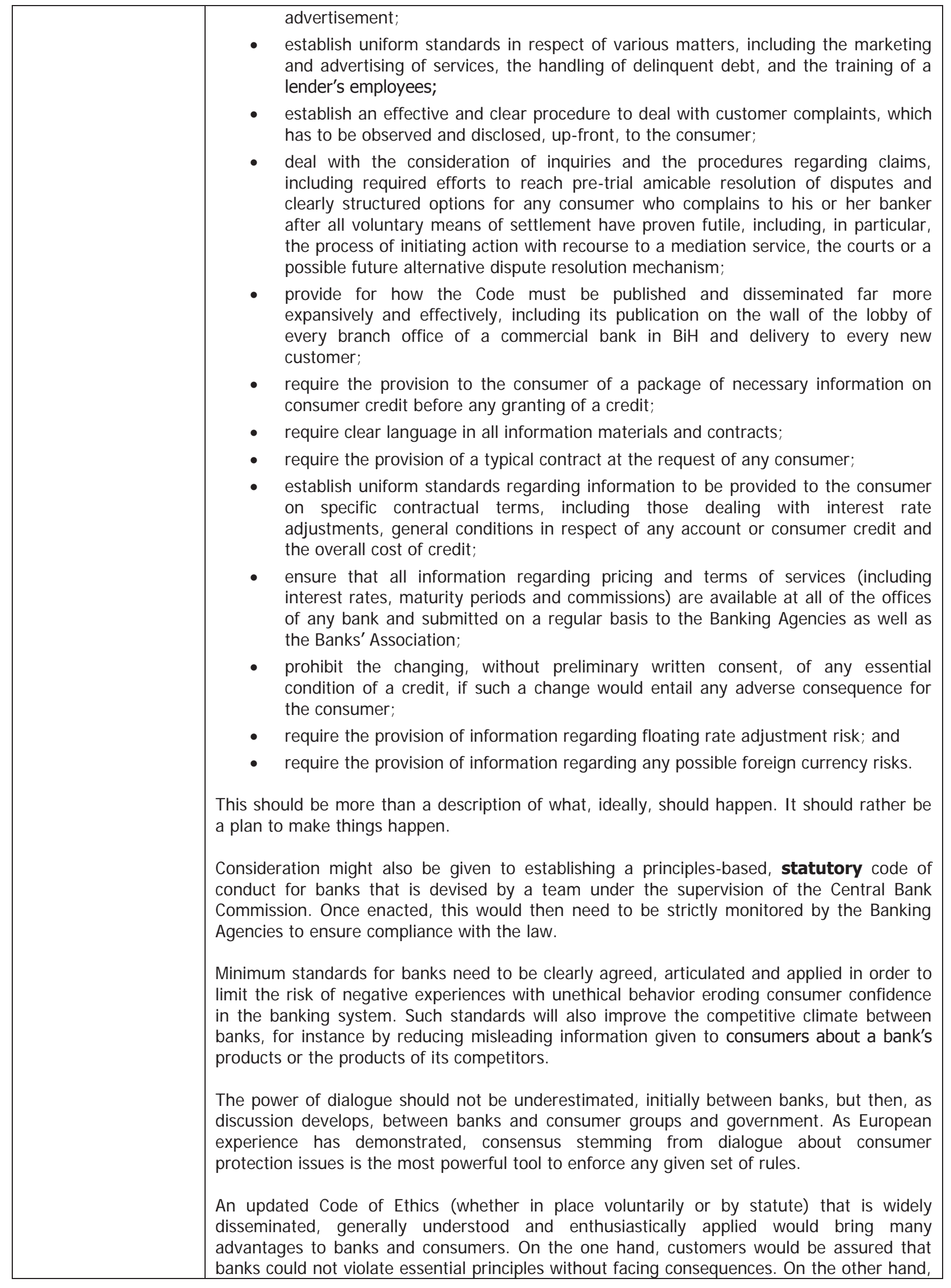




\begin{tabular}{|c|c|}
\hline & $\begin{array}{l}\text { the "best" banks in these respects would quickly stand out and presumably benefit from } \\
\text { greater business as a result. Although a series of what might be termed "mild" violations of } \\
\text { principles would perhaps lead to a high number of cases with a future alternative dispute } \\
\text { resolution mechanism, more serious violations should lead to a bank being deprived by the } \\
\text { Banks' Association from advertising its adherence to the Code or from membership in the } \\
\text { Association itself. In an increasingly competitive market, banks will consider this outcome as } \\
\text { undesirable since a general reputation for unethical practice would obviously hurt business. }\end{array}$ \\
\hline SECTION B & DISCLOSURE AND SALES PRACTICES \\
\hline Good Practice B. 1 & $\begin{array}{l}\text { Know Your Customer } \\
\text { When making a recommendation to a consumer, a bank should gather, file and } \\
\text { record sufficient information from the consumer in order to ensure that the } \\
\text { bank's recommendation, product or service is appropriate to that consumer. The } \\
\text { extent of information the bank gathers should: (a) be appropriate to the nature } \\
\text { and complexity of the product or service being proposed to or sought by the } \\
\text { consumer; and (b) enable the bank to provide a professional service. }\end{array}$ \\
\hline Description & $\begin{array}{l}\text { While some banks in BiH have internal rules requiring the application of these practices, } \\
\text { these are apparently not yet widespread or routine. The only reference to these sorts of } \\
\text { practices in the Banks' Association's Code of Ethics is in Rule II A) } 3 \text { of the Code which } \\
\text { states, in part, that: Banks "will ...request information about the situation of the customer, } \\
\text { its needs and limits". There are no statutory requirements in these respects. }\end{array}$ \\
\hline Recommendation & $\begin{array}{l}\text { When making a recommendation to a consumer, any BiH commercial bank should be } \\
\text { required, by law, to gather, file and record sufficient information from the consumer in order } \\
\text { to ensure that its recommended product or service is appropriate to that consumer. The } \\
\text { extent of information the commercial bank gathers should: (a) be appropriate to the nature } \\
\text { and complexity of the product or service being proposed to, or sought by, the consumer; } \\
\text { and (b) enable the bank to provide a professional service to the consumer. }\end{array}$ \\
\hline Good Practice B. 2 & $\begin{array}{l}\text { Suitability } \\
\text { Having regard to the facts disclosed by a consumer and other relevant facts } \\
\text { about that consumer of which a bank is aware, the bank needs to ensure that: } \\
\text { a. Any product or service it offers to that consumer is suitable for that } \\
\text { consumer; } \\
\text { b. In offering a selection of product or service options to that consumer, the } \\
\text { product or service options contained in the selection represent only the } \\
\text { most suitable from the bank's range of products or services; and } \\
\text { c. In recommending a product or service to that consumer, the } \\
\text { recommended product or service is, in the reasonable view of the Bank, } \\
\text { the most suitable product or service for that consumer. }\end{array}$ \\
\hline Description & $\begin{array}{l}\text { There is nothing in the existing law or in the Code of Ethics of the Banks' Association that } \\
\text { deals explicitly with this topic. As indicted above, by the terms of the Code of Conduct, } \\
\text { banks are simply admonished to provide consumers with "accurate and useful information } \\
\text { related to the characteristics of products or services offered and related to the terms, tariffs } \\
\text { and decisions applied." }{ }^{\prime 61} \text { Some banks do voluntarily seek, however, to ensure at least some } \\
\text { elements of suitability. }\end{array}$ \\
\hline Recommendation & $\begin{array}{l}\text { Having regard to the facts disclosed by a consumer and other relevant facts about that } \\
\text { consumer of which any commercial bank is aware, the bank needs to ensure that: } \\
\text { a) any product or service it offers to that consumer is suitable for that consumer; } \\
\text { b) in offering a selection of product or service options to that consumer, the product } \\
\text { or service options contained in the selection represent only the most suitable from } \\
\text { the bank's range of products or services; and } \\
\text { c) in recommending a product or service to that consumer, the recommended product }\end{array}$ \\
\hline
\end{tabular}

\footnotetext{
${ }^{61}$ See Rule II a) 3 of the Code of Ethics.
} 


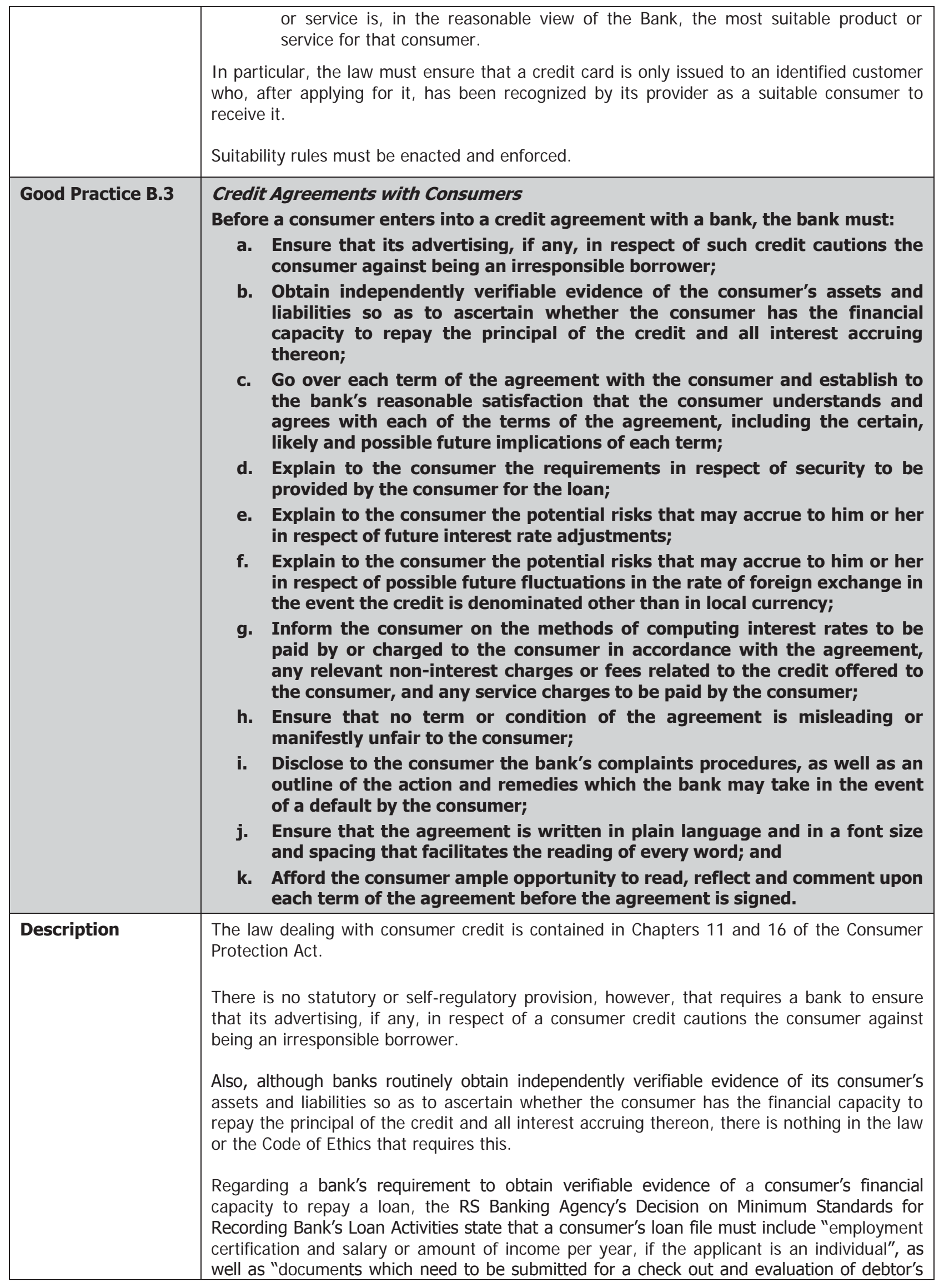


financial condition and its capability to repay the loan according to the agreed conditions with the analysis done, that is, authorized by bank's responsible officer which determines that debtor's cash flows are available for loan repayment ${ }^{\prime \prime 2}$. Similar provisions are in force in the $\mathrm{FBiH}^{63}$

Also, the RS Banking Agency's Decision on Credit Risk Management and Asset Classification requires that banks' loan files contain documents showing, among other elements: "the beneficiary's financial state and ability to repay the funds, the dynamics and repayment sources" ${ }^{\prime \prime 4}$

The Consumer Protection Act requires that, prior to the signing of a consumer credit agreement, a bank must provide its consumer in writing with the bank's requirements in respect of any security the consumer must supply to obtain the credit. ${ }^{65}$

Although the Consumer Protection Act requires, as well, that, prior to the signing of a consumer credit agreement, a bank must provide its consumer in writing with the annual interest rate for the credit and the terms and conditions of changes, if any, to that rate, ${ }^{66}$ there is no legal or self-regulatory requirement for a bank to explain to its consumer the potential risks that may accrue to him or her in respect of any future interest rate adjustment.

In addition, there is no legal or self-regulatory requirement for a bank to explain to its consumer the potential risks that may accrue to him or her in respect of possible future fluctuations in the rate of foreign exchange in the event the credit to that consumer is denominated other than in KMs.

While the Consumer Protection Act requires a bank to provide its consumer the "terms and conditions of changes to the annual interest rate" in writing prior to the signing of a consumer credit agreement, banks now must also stipulate in their contracts on loans or deposits whether the nominal interest rate may change as an element of the effective interest rate. If this is the case, the bank "must clearly define conditions of such changes in the ... contract." 67 While this formulation begs the questions what constitutes "clearly defined conditions" and who decides, the consumer is, at least ideally, now informed of the method his or her bank will employ in computing adjustments in interest rates to be paid by, or charged to, the consumer in accordance with his or her credit agreement.

It is in respect of changes made by certain BiH banks in their floating interest rates early in 2009 that the $\mathrm{BiH}$ banking community was accused of "loan sharking" by the media. Although rates in some instances rose, while at the same time as the EURIBOR was falling, the $\mathrm{BiH}$ banking industry was then, and remains, highly competitive. Present average interest rates, of $8 \%$ to $10 \%$ on consumer loans, are some $10 \%$ lower than they were a decade ago and these rates are highly favorable to the $\mathrm{BiH}$ consumer when compared to rates prevailing in other countries in the Region. That said, more or less standard prevailing practice in at least some $\mathrm{BiH}$ banks was to insert a clause in their loan agreements, whether with consumers or legal entities, that allowed the bank to adjust its rates whenever the bank deemed it appropriate on the basis either of: (a) EURIBOR, without indicating anything more; or (b) the decision of the bank's senior management or owners.

Complaints were first brought in the Federation, however, to the effect that these sorts of

\footnotetext{
${ }^{62}$ See Article 4 (6) and (7) of the Decision of the Managing Board of the RS Banking Agency on Minimum Standards for Recording Bank's Loan Activities of March 2003.

${ }^{63}$ See Article 3 (6) and (7) of the Decision of the Managing Board of the FBiH Banking Agency on Minimum Standards for Recording Bank's Loan Activities of December 2002.

${ }^{64}$ See Article 9 of the Decision of the Managing Board of the RS Banking Agency on Regulating Minimum Standards for Credit Risk Management and Banks Asset Classification of February 2003.

${ }^{65}$ See Article 54 (2) a) 8) of the Consumer Protection Act.

${ }^{66}$ See Article 54 (2) a) 5) and 6) of the Consumer Protection Act. See also, Article 58 (2) b) and c).

${ }^{67}$ See Decision of the Management Board of the FBiH Banking Agency on Amendments to Decision on Uniform Method of the Effective Interest Rate, dated 24 J une 2009.
} 


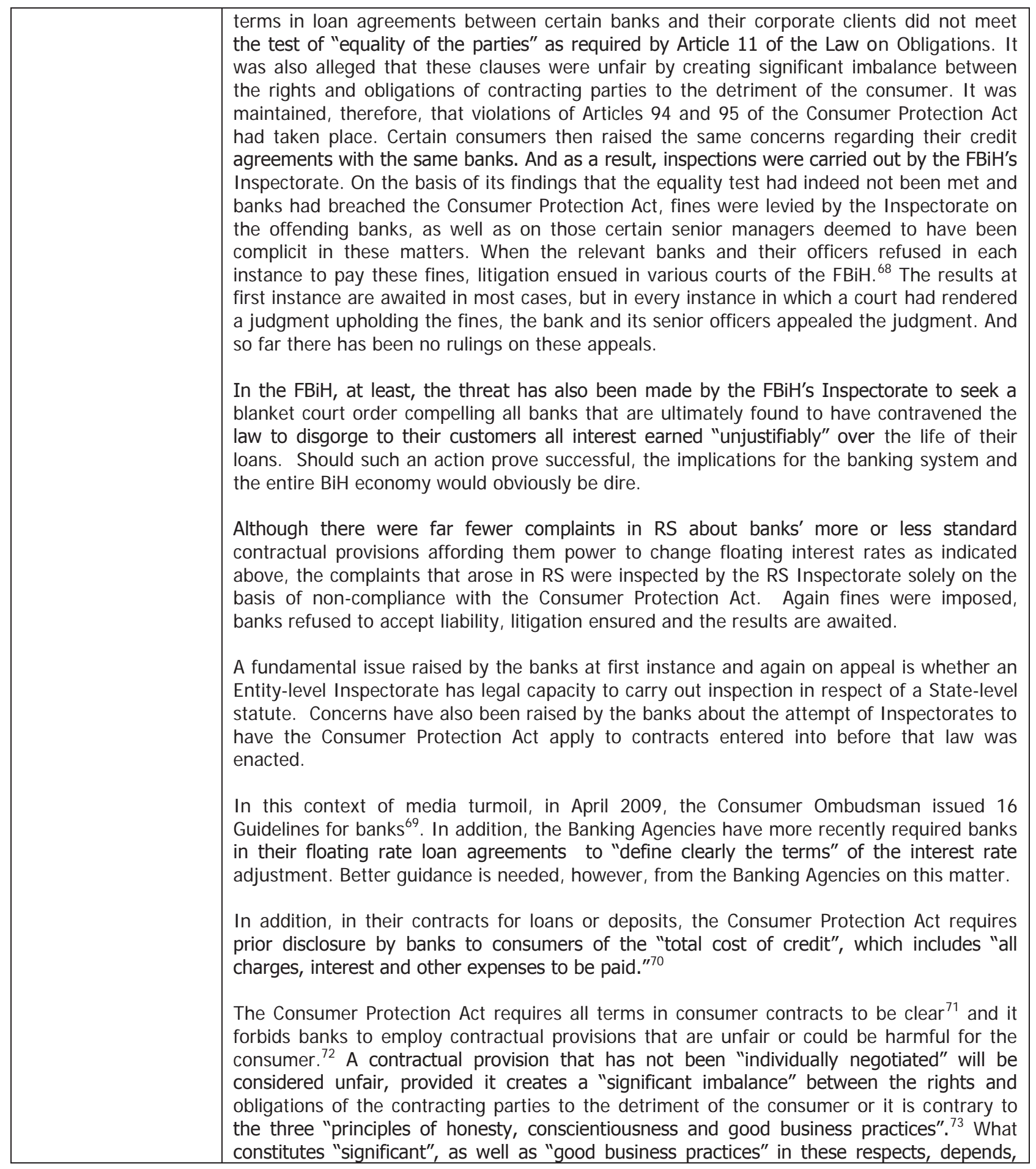

\footnotetext{
${ }^{68}$ As of September 2009, Sarajevos's Municipal Court had fined four banks for violation of consumer rights in the first instance, based on the FBiH Inspectorate's reports. The fines ranged from KM 2,500 to KM 20,000 per institution. An executive director was also fined KM 1,000.

${ }^{69}$ See Guidelines and Recommendations in the Sector of Consumer Loans, issued by the Institution of the Ombudsman for Consumer Protection in BiH on April 28, 2009.

${ }^{70}$ See Article 55 (1), as well as Article 56 (1) which defines "annual rate of credit costs."

${ }^{71}$ See Article 93 (2).

72 See Article 94 (1). By Article 94 (2), any contractual provision that is unfair is "null and void".

${ }^{73}$ See paragraphs a) and c) of Article 95 . The terms "conscientiousness" and "good business practices" are undefined.
} 


\begin{tabular}{|c|c|}
\hline & $\begin{array}{l}\text { however, on the facts and is subject to interpretation. } \\
\text { There is no legal or self-regulatory requirement for a bank to disclose to a consumer the } \\
\text { bank's complaints procedures, as well as an outline of the action and remedies which the } \\
\text { bank may take in the event of a default by the consumer. } \\
\text { Nor is there any legal or self-regulatory requirement that a consumer credit agreement be } \\
\text { written in plain language and in a font size and spacing that facilitates the reading of every } \\
\text { word. } \\
\text { And finally, there is, again, nothing in either the Consumer Protection Act or the Code of } \\
\text { Ethics that requires a bank to afford its consumer any, let alone "ample", opportunity to } \\
\text { read, reflect and comment upon each term of his or her credit agreement before the } \\
\text { agreement is signed. }\end{array}$ \\
\hline Recommendation & $\begin{array}{l}\text { Consideration should be given to amending the law so as to require that, prior to having a } \\
\text { consumer enter into a consumer credit agreement with it, a bank must: } \\
\text { a) ensure that its advertising, if any, in respect of the credit cautions the consumer } \\
\text { against being an irresponsible borrower; } \\
\text { b) obtain independently verifiable evidence of its consumer's assets and liabilities in } \\
\text { order to ascertain whether the consumer has the financial capacity to repay the } \\
\text { principal of the credit and all interest accruing thereon; } \\
\text { go over each term of the agreement with the consumer so as to establish to the } \\
\text { bank's reasonable satisfaction that the consumer understands and agrees with each } \\
\text { term of the agreement, including the certain, likely and possible future implications of } \\
\text { each term; } \\
\text { d) explain to the consumer the potential risks that may accrue to him or her in respect } \\
\text { of future interest rate adjustments, if any; } \\
\text { e) explain to the consumer the potential risks that may accrue to him or her in respect } \\
\text { of possible future fluctuations in the rate of foreign exchange in the event the credit } \\
\text { is denominated other than in KMs; } \\
\text { set forth why, when and on what basis, a floating interest rate may adjust, ideally } \\
\text { with reference to an objective and widely-publicized reference point and with a stated } \\
\text { cap for each adjustment (either upward or downward), as well as a stated total cap } \\
\text { (upward or downward) over the entire term of the credit; } \\
\text { g) disclose to the consumer the bank's complaints procedures, as well as an outline of } \\
\text { the action and remedies which the bank may take in the event of a default by the } \\
\text { consumer; } \\
\text { ensure that the agreement be written in plain language and in a font size and spacing } \\
\text { that facilitates the reading of every word; and } \\
\text { afford its consumer ample opportunity to read, reflect and comment upon each term } \\
\text { of the agreement. } \\
\text { possible. For purposes of discussion, a proposal is suggested in the Annex. } \\
\text { in the extent of public concern still surrounding the questions of how, when and why } \\
\text { ingency so }\end{array}$ \\
\hline Good Practice B. 4 & $\begin{array}{l}\text { Cooling-off Period } \\
\text { Unless explicitly waived in advance by a consumer in writing, a bank should } \\
\text { provide the consumer a "cooling-off" period of at least seven, but preferably } \\
\text { fourteen, days immediately following the signing of any loan agreement between } \\
\text { the bank and the consumer during which time the consumer may, on written } \\
\text { notice to the bank and the return of all monies received, treat the agreement as } \\
\text { null and void without penalty to the consumer of any kind. }\end{array}$ \\
\hline Description & The basic rules of contract in these respects are contained in the BiH Law of Obligations \\
\hline
\end{tabular}




\begin{tabular}{|c|c|}
\hline & 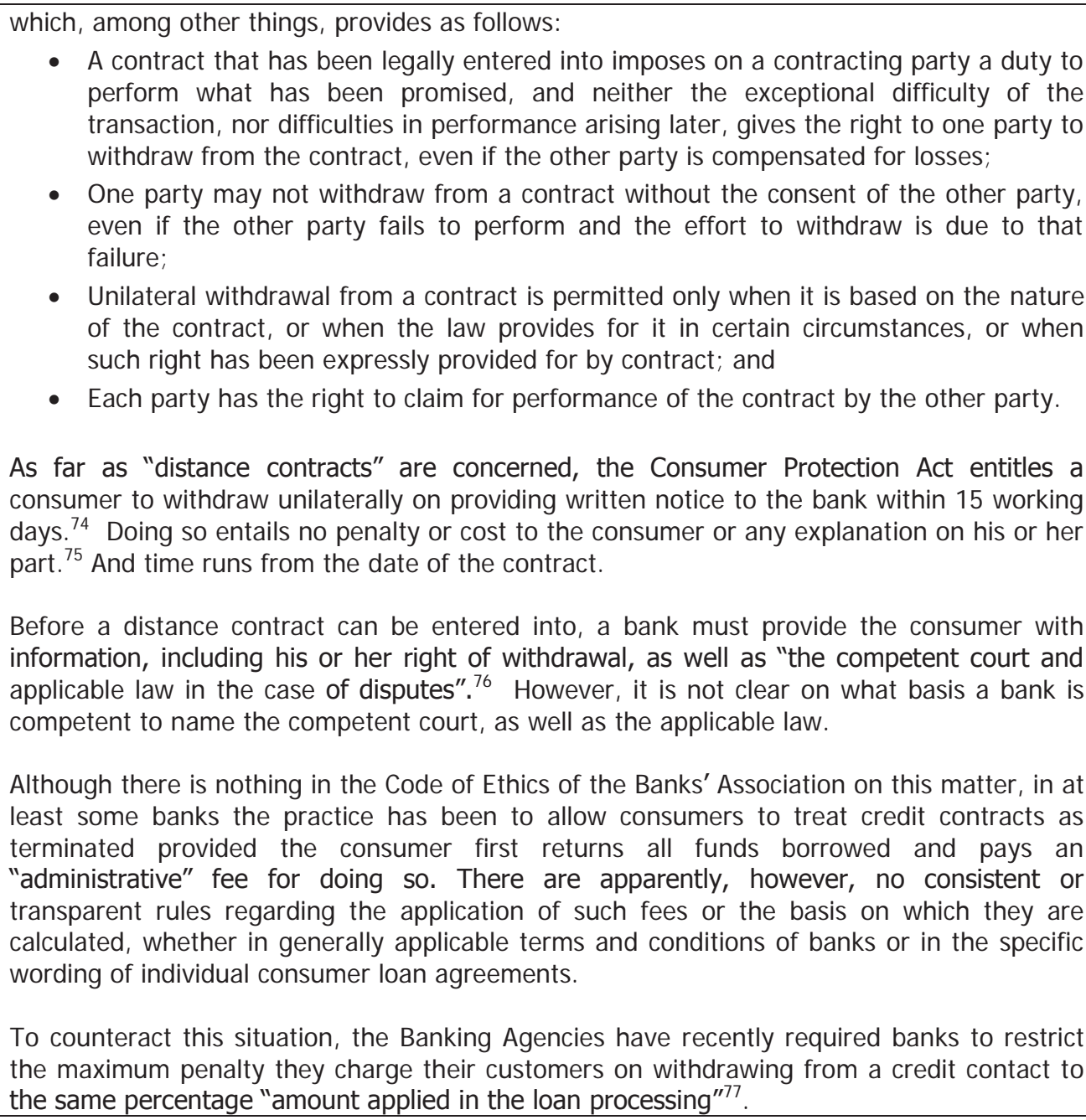 \\
\hline Recommendation & $\begin{array}{l}\text { Consideration should be given to amending the law to apply the distance contract provisions } \\
\text { on cooling-off periods to all loans to consumers. }\end{array}$ \\
\hline Good Practice B. 5 & $\begin{array}{l}\text { Linked Products and Bundling Clauses } \\
\text { Whenever a borrower is obliged by a bank to purchase any product, including an } \\
\text { insurance policy, as a pre-condition for receiving a loan from the bank, the } \\
\text { borrower should be free to choose the provider of the product. }\end{array}$ \\
\hline Description & $\begin{array}{l}\text { There is nothing in State- or Entity-level law or in the Code of Ethics of the Banks' } \\
\text { Association that deals explicitly with this matter. }\end{array}$ \\
\hline Recommendations & $\begin{array}{l}\text { Bundling of a product or service by a bank with a second product or service that is provided } \\
\text { by an entity that is affiliated in any way with the bank should only be permissible by law if } \\
\text { the consumer: (1) receives prior transparent notice in writing of the bundling and clear } \\
\text { statements regarding: (a) its implications in terms of cost to the consumer; and (b) the } \\
\text { nature of the bundling and what precisely is and is not covered as a result; and ( } 2 \text { ) then } \\
\text { agrees in writing with the bank to waive his or her right to proceed with unbundled } \\
\text { products. }\end{array}$ \\
\hline
\end{tabular}

\footnotetext{
${ }^{74}$ See Article 47 (1) of the Consumer Protection Act

$75 \mathrm{Ibid}$.

${ }^{76}$ See Article 44 (1) i) and I).

${ }^{77} \mathrm{See}$, for example, Article 2 of the Decision of the FBiH Banking Agency dated 24 June 2009.
} 


\begin{tabular}{|c|c|}
\hline & $\begin{array}{l}\text { the event that any accompanying service is offered to the consumer in the context of a } \\
\text { consumer credit. }\end{array}$ \\
\hline Good Practice B. 6 & $\begin{array}{l}\text { Preservation of Rights } \\
\text { Except where permitted by applicable legislation, in any communication or } \\
\text { agreement with a consumer, a bank should not exclude or restrict, or seek to } \\
\text { exclude or restrict: } \\
\text { a. Any statutory liability or duty of care of the bank to the consumer; } \\
\text { b. Any duty to act with skill, care and diligence toward the consumer in } \\
\text { connection with the provision by the bank of any banking service or } \\
\text { product; or } \\
\text { c. Any liability arising from the bank's failure to exercise the degree of skill, } \\
\text { care and diligence that may reasonably be expected of it in the provision } \\
\text { of any banking service or product to the consumer. }\end{array}$ \\
\hline Description & $\begin{array}{l}\text { The statutory duty of a bank to act with skill and care toward its consumers is contained in } \\
\text { the Law on Obligations. By its terms, "a party to a bond relation (i.e. a contract) is obliged } \\
\text { to act with care which is expected in the corresponding type of obligations, in legal } \\
\text { transactions (good businessman's care or good host's care)." }{ }^{78} \text { Banks are therefore required } \\
\text { to apply good banker's care. "When fulfilling an obligation related to its professional activity } \\
\text { (e.g. banking) [, however,] a party to a bond relation (in this case a bank) is obliged to act } \\
\text { with greater care and in accordance with rules of its profession and with (relevant) business } \\
\text { practices (good expert's care)." Query, however, whether the Code of Ethics of the Banks' } \\
\text { Association constitutes any evidence of banking business practices. There is apparently no } \\
\text { case in BiH of any bank either excluding or restricting or seeking to exclude or restrict the } \\
\text { application of these provisions and, thus, items a. and b, above are being complied with. } \\
\text { The liability, if any, that arises from a bank's failure to exercise the degree of skill, care and } \\
\text { diligence that may reasonably be expected of it in the provision of any banking service or } \\
\text { product to a consumer, arises from the agreement between the bank and the consumer. } \\
\text { And this agreement can, in fact, restrict potential responsibility of the bank for damages } \\
\text { based on the breach of any contractual obligation of the bank, provided the breach resulted } \\
\text { from simple negligence. If the bank acted, however, either with intent or gross negligence, } \\
\text { then any agreed exclusion of liability would not apply and the impact in law would sound } \\
\text { essentially in what would likely prove to be an increased amount of compensation to the } \\
\text { consumer by way of damages. }\end{array}$ \\
\hline Recommendation & $\begin{array}{l}\text { By the terms of the revised, fully endorsed and widely-publicized Banks' Association's Code } \\
\text { of Ethics, in any communication or agreement with a consumer, a bank should be prevented } \\
\text { from excluding or restricting, or from seeking to exclude or restrict, any liability arising from } \\
\text { the bank's failure to exercise the degree of skill, care and diligence that may reasonably be } \\
\text { expected of it in the provision of any banking service or product to the consumer. }\end{array}$ \\
\hline Good Practice B. 7 & $\begin{array}{l}\text { Regulatory Status Disclosure } \\
\text { In all of its advertising, whether by print, television, radio or otherwise, a bank } \\
\text { should disclose: (a) that it is regulated; and (b) the name and address of the } \\
\text { regulator. }\end{array}$ \\
\hline Description & $\begin{array}{l}\text { The Law on Banks of the FBiH simply requires, as a general rule, that "no one ... use the } \\
\text { word "bank" or derivatives of the word "bank" in respect of a business, product or service } \\
\text { without a banking or authorization issued by the [Banking] Agency ... ".79 A similar provision } \\
\text { exists in the Law on Banks of the RS. In neither instance, however, is there any mention of } \\
\text { a requirement to disclose that the company is regulated and by whom. Nor is there any } \\
\text { provision in this respect in the Banks' Association's Code of Ethics. }\end{array}$ \\
\hline Recommendation & $\begin{array}{l}\text { The law should be amended to require any BiH bank to disclose in any advertising: (a) that } \\
\text { it is regulated by one or both Banking Agencies; and (b) the name and address of the } \\
\text { relevant Banking Agency or Agencies. Or, at the very least, this requirement should be } \\
\text { included in any new or revised banking industry Code of Ethics. }\end{array}$ \\
\hline
\end{tabular}

\footnotetext{
${ }^{78}$ See Law of Obligations, Article 18

${ }^{79}$ See the FBiH Law on Banks, Article 2, paragraph 3
} 


\begin{tabular}{|c|c|}
\hline Good Practice B. 8 & $\begin{array}{l}\text { Terms and Conditions } \\
\text { Before a consumer may open a deposit, current or loan account at a bank, the } \\
\text { bank must provide the consumer with a written copy of its general terms and } \\
\text { conditions, as well as all terms and conditions that apply to the account to be } \\
\text { opened. Collectively, these Terms and Conditions must: } \\
\text { a. Disclose details of the bank's general charges, the bank's complaints } \\
\text { procedures, information about any compensation scheme that the bank is } \\
\text { a member of, and an outline of the action and remedies which the bank } \\
\text { may take in the event of a default by the consumer; } \\
\text { b. Include information on the methods of computing interest rates paid by or } \\
\text { charged to the consumer, any relevant non-interest charges or fees } \\
\text { related to the product offered to the consumer, any service charges to be } \\
\text { paid by the consumer, restrictions, if any, on account transfers by the } \\
\text { consumer and the procedures for closing an account; } \\
\text { c. Set forth clear rules regarding: (i) the reporting of unauthorized } \\
\text { transactions; (ii) stolen cards; and (iii) liability; and } \\
\text { d. Be written in plain language and in a font size and spacing that facilitates } \\
\text { the reading of every word. }\end{array}$ \\
\hline Description & $\begin{array}{l}\text { By the FBiH's Law on Banks, each bank is obliged "regularly [to] notify its customers of the } \\
\text { terms and conditions associated with the deposits made and the credits received by them, } \\
\text { including the annual interest rate. }{ }^{80} \text { A similar provision exists in the RS Law on Banks. }{ }^{81} \\
\text { Apart from these very general provisions, however, there is no legal requirement for a BiH } \\
\text { bank to provide a consumer with a written copy of its general terms and conditions before } \\
\text { the consumer opens any type of account at a bank. In addition, a BiH bank that is a } \\
\text { member of the State's deposit insurance program is also under no obligation }{ }^{82} \text { to provide } \\
\text { information at any time to a consumer regarding the guaranteed compensation amount and } \\
\text { its potential payment procedures in respect of his or her eligible deposits. } \\
\text { The Consumer Protection Act does require, however, that prior to entering a consumer } \\
\text { contract, the consumer must receive information in writing about the terms and conditions } \\
\text { of that contract. }{ }^{83} \text { And, for credit agreements generally, this information must include: a) } \\
\text { net amount of credit; b) the total cost of credit; c) the terms and conditions for early credit } \\
\text { repayment, d) the terms and conditions for the termination of the contract, including in case } \\
\text { of default by the consumer; e) the annual interest rate for credit in annual terms; f) the } \\
\text { terms and conditions of changes to the annual interest rate; g) insurance costs for the } \\
\text { outstanding debt or any other insurance concluded further to the credit agreements; and h) } \\
\text { the securities to be given. } \\
\text { The } \\
\text { The Banks' Association's Code of Ethics only mentions that a bank shall "provide any } \\
\text { consumer accurate and useful information related to the characteristics of products or } \\
\text { services on offer, as well as to the terms, tariffs and decisions applied". The Code also } \\
\text { requires banks to "ensure that there are no vague terms in its business policy documents, } \\
\text { application forms and access contracts, which would impose undefined commitments on } \\
\text { consumers, thereby bringing uncertainty to the consumer regarding his or her rights and } \\
\text { obligations". } \\
\text { The regime for contractual terms and commercial practices that are unfair to the consumer } \\
\text { is, however, provided in the Consumer Protection Act. }\end{array}$ \\
\hline Recommendation & $\begin{array}{l}\text { Consideration should be given to requiring by statute that, before a consumer opens a } \\
\text { deposit, current or loan account at any bank, the bank must provide the consumer with a } \\
\text { written copy of its general terms and conditions, as well as all terms and conditions that }\end{array}$ \\
\hline
\end{tabular}

\footnotetext{
${ }^{80}$ See Article 45 of the FBiH Law on Banks.

${ }^{81}$ See Article 98 of the RS Law on Banks.

${ }^{82}$ See the State's Law on Deposit Insurance.

${ }^{83}$ Article 54 (1) of the Consumer Protection Act

${ }^{84}$ Ibid., Article 54 (2) a)
} 


\begin{tabular}{|c|c|}
\hline & $\begin{array}{l}\text { apply to the account to be opened. These Terms and Conditions should then: } \\
\text { i) disclose details of the bank's general charges, the bank's complaints procedures, } \\
\text { information about any compensation scheme that the bank is a member of, and an } \\
\text { outline of the action and remedies which the bank may take in the event of a default } \\
\text { by the consumer; } \\
\text { ii) include information on the methods of computing interest rates paid by or charged } \\
\text { to the consumer, any relevant non-interest charges or fees related to the product } \\
\text { offered to the consumer, any service charges to be paid by the consumer, } \\
\text { restrictions, if any, on account transfers by the consumer and the procedures for } \\
\text { closing an account; } \\
\text { iii) } \\
\text { set forth clear rules regarding: (a) the reporting of unauthorized transactions; (b) } \\
\text { iv) be written in plain language and in a font size and spacing that facilitates the } \\
\text { reading of every word. } \\
\text { In this respect, the provisions of the EU Directive } 2008 / 48 / E C \text { of } 23 \text { April } 2008 \text { are relevant. } \\
\text { A further area which is becoming common practice in many European countries is to provide } \\
\text { the consumer with some stress tests of the products they are purchasing. This is largely } \\
\text { applicable to mortgage loans which may be subject to wide variations in cost due to variable } \\
\text { interest rates or currency movements. } \\
\text { It is suggested that the Banks' Association produce a standard set of easily understandable } \\
\text { scenarios which should be given to consumers --prior to signing any credit agreement with a } \\
\text { variable interest rate or denominated in a currency other than KMs. These scenarios could } \\
\text { include the impact of increasing the interest rate by } 2 \text { or } 3 \text { per cent, or the impact of a } \\
\text { change in the value of the KM relative to the currency of the credit. This information could } \\
\text { also form part of the Key Facts documentation detailed below. }\end{array}$ \\
\hline Good Practice B. 9 & $\begin{array}{l}\text { Key Facts Statement } \\
\text { a. A bank should have a single-page Key Facts Statement, written in plain } \\
\text { language, in respect of each of its accounts, types of loans or other } \\
\text { products. } \\
\text { b. Prior to a consumer opening any account at, or signing any loan } \\
\text { agreement with, the bank, the consumer should have delivered a signed } \\
\text { statement to the bank to the effect that he or she has duly received a } \\
\text { copy of the relevant document from the bank. }\end{array}$ \\
\hline Description & $\begin{array}{l}\text { Neither the law requires a bank to produce such a document, nor does the Banks' } \\
\text { Association's Code of Ethics recommend this practice. Although most banks do produce } \\
\text { small, folded glossy pamphlets regarding at least each of their major consumer products and } \\
\text { services, these in no way substitute for Key Facts Statements which invariably help } \\
\text { consumers in comparison shopping with and between banks, thereby permitting consumers } \\
\text { to choose products and services wisely that meet their requirements on terms they can } \\
\text { properly accept. } \\
\text { That said, the kernel of the idea is contained in the Banks' Association's Code of Ethics. By } \\
\text { Article II A) 3, "Banks shall provide to customers accurate and useful information related to } \\
\text { the characteristics of products and services offered, and related to the terms, tariffs and } \\
\text { decisions applied." However, no BiH bank appears to use Key Facts Statements, as such, for } \\
\text { any of their accounts or loan products. }\end{array}$ \\
\hline Recommendation & $\begin{array}{l}\text { The law should be amended to require banks to provide the consumer with a Key Facts } \\
\text { Statement for each product or service offered. And, prior to a consumer opening any } \\
\text { account at, or signing any loan agreement with, a bank, the consumer should have delivered } \\
\text { a signed statement to the bank to the effect that he or she has duly received a copy of the } \\
\text { relevant Key Facts Statement from the bank. }\end{array}$ \\
\hline
\end{tabular}




\begin{tabular}{|c|c|}
\hline Good Practice B.10 & $\begin{array}{l}\text { Guarantees } \\
\text { No advertisement by a bank should describe either an actual or future deposit or } \\
\text { interest rate payable on a deposit as being guaranteed or partially guaranteed } \\
\text { unless: } \\
\text { a. There is a legally enforceable agreement between the bank and a third } \\
\text { party who or which has provided such a guarantee; and } \\
\text { b. The advertisement states: } \\
\text { (i) the extent of the guarantee; } \\
\text { (ii) the name and address of the party providing the guarantee; and } \\
\text { (ii) in the event that that party is in any way connected to the bank, the } \\
\text { precise nature of that connection. }\end{array}$ \\
\hline Description & $\begin{array}{l}\text { By the terms of the Law on Obligations: } \\
\text { a) A contract promising that a third person will perform something binds neither the } \\
\text { promisor nor the third person, unless: } \\
\text { 1) someone undertakes the obligations of another person's debt; } \\
\text { 2) someone promises to procure a guarantor for oneself; } \\
\text { 3) a person's manager makes a promise and asserts that this third person shall } \\
\text { confirm it; or } \\
\text { 4) a promise has been made securing performance with contractual penalties or by } \\
\text { undertaking to compensate for any loss. } \\
\text { In all such cases, contractual penalties or compensation for losses shall be paid if the } \\
\text { promise is not kept; and } \\
\text { If someone makes a promise either to ensure that a third person performs } \\
\text { something, or to induce him or her to perform it, then it shall be an action of the } \\
\text { promisor himself or herself, and therefore, the promisor shall compensate for losses if } \\
\text { the third person does not undertake to perform such action. } \\
\text { Regardless of any underlying substantive law, however, besides the existing deposit } \\
\text { insurance regime (which is based upon legally enforceable statutory obligations), }{ }^{85} \text { there is } \\
\text { nothing in either Entity's Law on Banks, the Law on Obligations or apparently any other Law } \\
\text { or regulation that deals in any way with advertisements of guarantees of a bank deposit or } \\
\text { of guarantees of an interest rate payable on a bank deposit. And there is, likewise, nothing } \\
\text { in the Banks' Association' Code of Ethics that touches on this subject. }\end{array}$ \\
\hline Recommendation & $\begin{array}{l}\text { The law should require that no advertisement by a BiH bank may be made that describes } \\
\text { either an actual or future deposit or interest rate payable on a deposit as being guaranteed } \\
\text { or partially guaranteed unless: } \\
\text { a. there is a legally enforceable agreement between the bank and a third party who or } \\
\text { which has provided the guarantee; and } \\
\text { b. the advertisement states: } \\
\begin{array}{l}\text { (i) the extent of the guarantee; } \\
\text { (ii) the name and address of the party providing the guarantee; and } \\
\text { (iii) in the event that that party is in any way connected to the bank, the } \\
\text { precise nature of that connection. }\end{array}\end{array}$ \\
\hline Good Practice B.11 & $\begin{array}{l}\text { Professional Competence } \\
\text { a. In order to avoid any misrepresentation of fact to a consumer, any bank } \\
\text { staff member who deals directly with consumers, or who prepares bank } \\
\text { advertisements or who markets any service or product of the bank should } \\
\text { be familiar with all legislative, regulatory and code of conduct guidance } \\
\text { requirements relevant to his or her work, as well as with the details of any } \\
\text { product or service of the bank which he or she sells or promotes. } \\
\text { b. Regulators and industry associations should collaborate to establish and } \\
\text { administer minimum competency requirements for any bank staff member } \\
\text { who: }\end{array}$ \\
\hline
\end{tabular}

\footnotetext{
${ }^{85}$ See Good Practice F. 1 below.
} 


\begin{tabular}{|c|c|}
\hline & $\begin{array}{l}\text { (i) deals directly with consumers; } \\
\text { (ii) prepares any Key Facts Statement or any advertisement for the bank; } \\
\text { or } \\
\text { (iii) markets the bank's services and products. }\end{array}$ \\
\hline Description & $\begin{array}{l}\text { Some banks, and apparently all that are foreign-owned, take it upon themselves to ensure } \\
\text { that their staff members (at least those under categories b (i) and (iii) above) receive what } \\
\text { they consider to be "adequate" in-house training before staff embark on client-oriented } \\
\text { functions. But, from the perspective of what would be best for the BiH banking industry and } \\
\text { for consumers as a whole, unfortunately no generally agreed industry standard exists in } \\
\text { these respects. } \\
\text { The Banks' Association's Code of Ethics states that banks "shall enable their staff to be } \\
\text { aware of products and services offered by the bank ..." }{ }^{86} \text { Also, banks are required to see } \\
\text { that "their staff will be trained to comply strictly with the rules about banking secrecy, and, } \\
\text { in general act with full discretion in contact with customers". } \\
\end{array}$ \\
\hline Recommendation & $\begin{array}{l}\text { The Banks' Association, possibly with the collaboration of the Banking Agencies, should } \\
\text { establish and administer minimum competency requirements at the very least for any staff } \\
\text { member of a bank who: } \\
\text { - deals directly with consumers; } \\
\text { - prepares any Key Facts Statement or any advertisement for the bank; or } \\
\text { - markets the bank's services and products. }\end{array}$ \\
\hline SECTION C & CUSTOMER ACCOUNT HANDLING AND MAINTENANCE \\
\hline Good Practice C.1 & $\begin{array}{l}\text { Statements } \\
\text { a. Unless a bank receives a customer's prior signed authorization to the } \\
\text { contrary, the bank should issue, and provide the customer with, a monthly } \\
\text { statement regarding every account the bank operates for the customer. } \\
\text { Each such statement should: } \\
\text { (i) set out all transactions concerning the account during the period } \\
\text { covered by the statement; and } \\
\text { (ii) provide details of the interest rate(s) applied to the account during } \\
\text { the period covered by the statement. } \\
\text { b. Each credit card statement must set out the minimum payment required } \\
\text { and the total interest cost that will accrue, if the cardholder makes only } \\
\text { the required minimum payment. } \\
\text { c. Each mortgage or other loan account statement must clearly indicate the } \\
\text { amount paid during the period covered by the statement, the total } \\
\text { outstanding amount still owing, the allocation of payment to the principal } \\
\text { and interest and, if applicable, the up-to-date accrual of taxes paid. } \\
\text { d. A bank must notify a customer of inactivity of any account of the customer } \\
\text { and provide a reasonable final notice in writing to the customer if the } \\
\text { funds are to be transferred to the government. } \\
\text { e. When an investor signs up for paperless statements, such statements } \\
\text { should be in an easy-to-read and readily understandable format. }\end{array}$ \\
\hline
\end{tabular}

\footnotetext{
${ }^{86}$ See Code of Ethics, II A) 1.

${ }^{87}$ (bid, II A) 4.
} 


\begin{tabular}{|c|c|}
\hline Description & $\begin{array}{l}\text { The Payment Transaction Law of each Entity requires a bank to provide its customer, at a } \\
\text { minimum, with a monthly account statement (for all types of accounts except "passbook } \\
\text { accounts"), identifying each credit and debit posted to the account since the last statement } \\
\text { and providing for the final balance. For a passbook account, a bank must facilitate the } \\
\text { ongoing update of the passbook upon its presentation by the customer, and in each update, } \\
\text { each credit or debit that is posted to the account since the previous update must be } \\
\text { recorded, as well as the final account balance. The Law also obliges banks to "investigate } \\
\text { any discrepancy or contested credit or debit, and where the facts are agreed or determined, } \\
\text { make all necessary adjustments and corrections. }{ }^{\prime \prime 8} \\
\text { The FBiH Law on Banks requires a bank to publish a notice listing all dormant deposit } \\
\text { accounts in at least three daily newspapers published in the FBiH Entity and at least one in } \\
\text { RS and one in the District every six months. After a dormant deposit account has been } \\
\text { published at least twice by the bank, the account and all its records are transferred to the } \\
\text { Ministry of Finance. Afterwards, the accountholder may submit proof of ownership of the } \\
\text { account funds to the Ministry, which then reviews the evidence and, if the proof is } \\
\text { satisfactory, returns the money to the accountholder. According to the RS Law on Bank, } \\
\text { banks are not bound to publish the lists of dormant accounts, but to prescribe the } \\
\text { procedures for treatment of dormant accounts. }\end{array}$ \\
\hline Recommendation & $\begin{array}{l}\text { The regulations need to be expanded to cover all aspects referred to above and then } \\
\text { effectively enforced. }\end{array}$ \\
\hline Good Practice C. 2 & $\begin{array}{l}\text { Notification of Changes in Interest Rates and Non-interest Charges } \\
\text { A customer of a bank must be notified in writing by the bank of any change in: } \\
\text { a. The interest rate to be paid or charged on any account of the customer, } \\
\text { as soon as practicably possible; and } \\
\text { b. A non-interest charge on any account of the customer, a reasonable } \\
\text { period in advance of the effective date of the change. }\end{array}$ \\
\hline Description & $\begin{array}{l}\text { By the terms of Article } 58 \text { of the Consumer Protection Act, the consumer should be informed } \\
\text { in writing of "each change of annual interest rates and other charges eight days in advance, } \\
\text { or exceptionally at the moment of such changes, if this period is less than eight days, as } \\
\text { well as at the moment of debiting the consumer's current account." } \\
\text { In respect of changes in conditions of loans, the FBiH Banking Agency's Decision on } \\
\text { Minimum Standards for Recording Bank's Loan Activities states that a bank can make } \\
\text { changes to the conditions of the loan only in written form and by adequate amendments } \\
\text { and annexes to the agreement }{ }^{90} \text {. } \\
\text { In case of variable interest rate loans, there is no benchmark or base interest rate that } \\
\text { would serve as guidance for consumers to know how the interest rate may change in the } \\
\text { future. After some banks increased their variable interest rates at a time when the EURIBOR } \\
\text { was decreasing in early } 2009 \text {, the Banking Agencies issued regulations requiring more clarity } \\
\text { in the conditions for changes of interest rates. For example, the FBiH Decision on } \\
\text { Amendments to Decision on Uniform Method of Effective Interest Rate Accrual and } \\
\text { Reporting on Loans and Deposits established in Article } 1 \text { that banks and microcredit } \\
\text { organizations "must clearly define conditions" of changes in interest rates of loan or deposit } \\
\text { contracts, where these contracts stipulate a possibility of nominal interest changes as an } \\
\text { element of the effective interest rate. However, there is no further specification of what } \\
\text { constitutes "clearly defined conditions". Article } 1 \text { of the FBiH Decision also obliges banks and } \\
\text { microcredit organizations to "inform customers in written form of the changes ... at latest } \\
\text { within } 30 \text { days". }\end{array}$ \\
\hline
\end{tabular}

\footnotetext{
${ }^{88}$ See Article 32 of the Payment Transaction Law of both the FBiH and the RS, approved in 2000.

${ }^{89}$ Article 45 a) of the FBiH Law on Banks and Article 99 of the RS Law on Banks.

${ }^{90}$ See Article 1 of the Decision of the Managing Board of the FBiH Banking Agency on Minimum Standards for Recording Bank's Loan Activities of December 2002, and Article 2 of the Decision of the Managing Board of the RS Banking Agency on Minimum Standards for Recording Bank's Loan Activities of March 2003.
} 


\begin{tabular}{|c|c|}
\hline & $\begin{array}{l}\text { - documents showing collateral or guarantee related to the loan; } \\
\text { - } \text { records with the cash amount for which the loan property has been insured with an } \\
\text { a record of changes and additions to the loan agreement, if any, after the loan } \\
\text { approval, } \\
\text { - documentation confirming and defining any action as required; } \\
\text { - all correspondence and documents showing contacts between the bank and debtor } \\
\text { after the loan agreement was approved. } \\
\text { The Decision also stipulates that the bank shall maintain the loan file as long as the loan is } \\
\text { not repaid or liquidated in other manner. } \\
\text { The legislation on prevention of money laundering and financing of terrorism sets up some } \\
\text { requirements regarding banks' identification of customers. For example, the RS Banking } \\
\text { Agency's Decision on Prevention of Money Laundering and Terrorism Financing requires } \\
\text { banks to ask for "all necessary documentation in order to have a full and accurate } \\
\text { identification of every new customer, as well as to determine the purpose and intended } \\
\text { nature of the business relationship with the bank. }{ }^{\text {"94 }} \text { For individuals wanting to become bank } \\
\text { customers, banks are required to ask for specific information and documents to determine } \\
\text { the individual's identity (e.g. full name, permanent address, date and place of birth, official } \\
\text { identity document showing a photograph of the person, and the name of the employer of } \\
\text { the individual). The Decision also requires banks to develop a profile of their customers and } \\
\text { to keep the documentation for all transactions performed by these customers and in } \\
\text { relationship with these customers }{ }^{95} \text {. Finally, the Decision also requires banks to "prescribe } \\
\text { standards for types of necessary documentation and time periods for maintaining such } \\
\text { information, at a minimum in accordance with appropriate regulations for maintaining } \\
\text { documentation." }\end{array}$ \\
\hline Recommendation & $\begin{array}{l}\text { The law should be amended to require simple and consistent requirements, as indicated } \\
\text { above, in respect of each customer for at least some years. }\end{array}$ \\
\hline Good Practice C. 4 & $\begin{array}{l}\text { Checks } \\
\text { The regime regarding the issuance and clearing of checks must be based on clear } \\
\text { statutory and regulatory rules that, among other things, set reasonable } \\
\text { requirements for banks on the following issues: } \\
\text { a. For any bank on which a check is drawn, when the account on which it is } \\
\text { drawn has insufficient funds; } \\
\text { b. For any bank at which a customer of that bank seeks to cash or deposit a } \\
\text { check, which is subsequently found to be drawn on an account with } \\
\text { insufficient funds; } \\
\text { c. Informing the customer of the consequences of issuing a check without } \\
\text { sufficient funds, at the time a customer opens a checking account; } \\
\text { d. Regarding the crediting of a customer's account and its timing, when a } \\
\text { check deposited by the customer clears; and } \\
\text { e. In respect of capping charges on the issuance and clearance of checks. }\end{array}$ \\
\hline Description & $\begin{array}{l}\text { There is no existing regime of checks in the BiH banking system. Rather, financial } \\
\text { transactions occur in cash or by bank transfers made in person, written order or } \\
\text { electronically. }\end{array}$ \\
\hline Recommendation & No recommendation. \\
\hline
\end{tabular}

\footnotetext{
${ }^{93}$ See Article 3 of the RS Banking Agency Decision and Article 2 of FBiH Banking Agency Decision.

${ }^{94}$ See Article 9 of the Decision of the Managing Board of the RS Banking Agency on Decision on Prevention of Money Laundering and Terrorism Financing of February 2003.

${ }_{95}$ Idem, Article 11.

${ }^{96}$ Idem, Article 8.
} 


\begin{tabular}{|c|c|}
\hline Good Practice C.5 & $\begin{array}{l}\text { Electronic Checks } \\
\text { a. Customers should be provided with consistent, clear and timely information } \\
\text { about electronic checks and the cost of using them, at all relevant stages in } \\
\text { a consumer's decision-making, in easily accessible and understandable } \\
\text { form. } \\
\text { b. Customers should be informed: } \\
\text { (i) how the use of a credit card check differs from the use of a credit } \\
\text { card; } \\
\text { (ii) of the interest rate that applies to the use of credit card check and } \\
\text { whether this differs from the rate charged for a credit card purchase; } \\
\text { (iii) when interest is charged and whether there is no interest free period; } \\
\text { (iv) whether additional fees or charges apply and, if so, on what basis and } \\
\text { the amount; and } \\
\text { (v) whether a purchase using a credit card check benefits from the same } \\
\text { protection as using a credit card. } \\
\text { c. Credit card checks should not be sent to consumers without prior consent. } \\
\text { d. Authorities should encourage efforts to enable end users to better } \\
\text { understand the market for electronic checks, such as providing comparative } \\
\text { price information and undertaking educational campaigns. } \\
\text { e. There should be clear rules regarding procedures for error resolution. }\end{array}$ \\
\hline Description & There is no existing regime of electronic checks in the BiH banking system. \\
\hline Recommendation & No recommendation. \\
\hline Good Practice C. 6 & $\begin{array}{l}\text { Electronic Fund Transfers and Remittances } \\
\text { a. There should be clear rules on the rights, liabilities and responsibilities of } \\
\text { the parties in electronic fund transfers. } \\
\text { b. Banks should provide information on prices and service features of } \\
\text { electronic fund transfers and remittances in easily accessible and } \\
\text { understandable forms. As far as possible, this information should include: } \\
\text { (i) the total price (e.g. fees at both ends, foreign exchange rates and } \\
\text { other costs); } \\
\text { (ii) the time it will take the funds to reach the receiver; } \\
\text { (iii) the locations of the access points for sender and receiver; } \\
\text { (iv) terms and conditions of the fund transfers services to the customer. } \\
\text { c. To ensure full transparency, it should be clear to the sender if the price or } \\
\text { other aspects of the service vary according to different circumstances, and } \\
\text { the bank should disclose the information without imposing requirements on } \\
\text { the consumer. } \\
\text { There should be a legal provision requiring documentation of electronic fund } \\
\text { transfers. } \\
\text { There should be clear, publicly available and easily applicable procedures in } \\
\text { cases of errors and frauds. } \\
\text { f. Authorities should encourage efforts to enable end users to better } \\
\text { understand the market for electronic fund transfers and remittances, such } \\
\text { as providing comparative price information or undertaking educational } \\
\text { campaigns. }\end{array}$ \\
\hline Description & $\begin{array}{l}\text { According to information provided by the World Bank, in } 2007 \text { BiH was among the top ten } \\
\text { remittance countries in Europe and Asia in terms of value, and among the top five when } \\
\text { considering remittances as a proportion of GDP. Remittances were approximately USD } 19 \\
\text { billion, representing } 17 \text { per cent of GDP. However, these statistics only consider remittances } \\
\text { made through official bank channels. It is estimated that remittances executed unofficially } \\
\text { represent around } 50 \text { percent of those conducted officially. } \\
\text { Despite the importance of remittances in the BiH economy, there is no law, regulation or }\end{array}$ \\
\hline
\end{tabular}




\begin{tabular}{|c|c|}
\hline & $\begin{array}{l}\text { guideline dealing with the particularities of electronic fund transfers or remittances. There is } \\
\text { only a general legal framework covering payment transactions, including transactions made } \\
\text { electronically. The law includes provisions on duties of a bank receiving a customer's order, } \\
\text { as well as liability, damages and restitutions regarding the execution of a customer's } \\
\text { payment order. }\end{array}$ \\
\hline Recommendation & $\begin{array}{l}\text { There should be specific legal or regulatory provisions or guidelines covering the elements } \\
\text { included in this good practice. }\end{array}$ \\
\hline Good Practice C. 7 & $\begin{array}{l}\text { Debt Recovery } \\
\text { a. No bank, agent of a bank or third party should employ any abusive debt } \\
\text { collection practice against any customer of the bank, including the use of } \\
\text { any false statement, any unfair practice or the giving of false credit } \\
\text { information to others. } \\
\text { b. The type of debt that can be collected on behalf of a bank, the person who } \\
\text { can collect any such debt and the manner in which that debt can be } \\
\text { collected must be indicated to the customer of the bank when the credit } \\
\text { agreement giving rise to the debt is entered into between the bank and } \\
\text { the customer. } \\
\text { c. No debt collector should contact any third party about a bank customer's } \\
\text { debt without informing that party of: (i) the debt collector's right to do so; } \\
\text { and (ii) the type of information that the debt collector is seeking. }\end{array}$ \\
\hline Description & $\begin{array}{l}\text { What few debt collection agencies apparently exist in } \mathrm{BiH} \text { are unlicensed and operate } \\
\text { without any regulatory oversight. As a result, concerns have been raised about the } \\
\text { possibility of unscrupulous behavior being employed to harass bank customer debtors. } \\
\text { Aware, however, of the negative impact such activity would have on their reputations, many } \\
\text { banks handle debt-collection "in-house". } \\
\text { Given their un-regulated status, it is not surprising that no official statistics are available } \\
\text { from any BiH debt collection agency on any aspect of its activities. } \\
\text { Debt relief at a reasonable cost is essential for any consumer unable to pay his or her debts } \\
\text { as they come due over some reasonable period of time. }\end{array}$ \\
\hline Recommendation & $\begin{array}{l}\text { A Law on Debt Collection Operations would be helpful, provided it would require, among } \\
\text { other things: } \\
\text { a. the licensing and oversight of all properly registered collection agencies by an } \\
\text { appropriate regulatory authority; } \\
\text { b. the provision of services in accordance with stated parameters on the basis of } \\
\text { generally acceptable fair and reasonable behavior; and } \\
\text { c. the provision of statistics by each licensed agency to the regulatory authority on a } \\
\text { regular basis for annual consolidation and wide-spread public dissemination. } \\
\text { In addition, the law must grant all consumers and their banks the right to re-schedule debts. }\end{array}$ \\
\hline SECTION D & PRIVACY AND DATA PROTECTION \\
\hline Good Practice D. 1 & $\begin{array}{l}\text { Confidentiality and Security of Customers' Information } \\
\text { Customers have a right to expect that their financial transactions are kept } \\
\text { confidential. The law should require banks to ensure that they protect the } \\
\text { confidentiality and security of personal data, against any anticipated threats or } \\
\text { hazards to the security or integrity of such information, and against unauthorized } \\
\text { access. }\end{array}$ \\
\hline Description & $\begin{array}{l}\text { The Law on the Protection of Personal Data (Article 11) requires that data controllers and } \\
\text { data processors take care of data security and take all necessary measures against } \\
\text { unauthorized or accidental access to personal data, their alteration, destruction or loss, } \\
\text { unauthorized transfer and other forms of illegal data processing, and against misuse of } \\
\text { personal data. The law also requires data controllers (and processors within the scope of } \\
\text { their competences) to develop a data security plan specifying technical and organizational }\end{array}$ \\
\hline
\end{tabular}




\begin{tabular}{|c|c|}
\hline & $\begin{array}{l}\text { measures to ensure security of personal data. In 2009, the Council of Ministers issued a by- } \\
\text { law prescribing the methodology of safekeeping and special measures of technical } \\
\text { protection. } \\
\text { According to Article } 16 \text { of the Law on the Protection of Personal Data, all persons who } \\
\text { process, or are in contact with, personal data in the premises of a data controller or } \\
\text { processor are required to maintain the confidentiality of such data. And the confidentiality } \\
\text { and security obligations remain in force after termination of employment or of any specific } \\
\text { task. } \\
\text { The Law establishes sanctions for violation of security and confidentiality provisions, } \\
\text { applicable to the data controller, as well as responsible persons and employees. } \\
\text { In addition, the FBiH and RS Payment Transaction Laws state that a bank is "bound by } \\
\text { confidentiality and may not disclose any information on the (bank) account to anyone other } \\
\text { than the customer, except otherwise regulated by law or authorized by the customer". } 97\end{array}$ \\
\hline Recommendation & No recommendation. \\
\hline Good Practice D. 2 & $\begin{array}{l}\text { Sharing Customer's Information } \\
\text { a. A bank should inform its customer in writing: (i) of any third-party dealing } \\
\text { for which the bank must share information regarding any account of the } \\
\text { customer, such as any legal enquiry by a credit bureau; and (ii) how it will } \\
\text { use and share the customer's personal information. } \\
\text { b. No bank shall sell or share account or personal information regarding a } \\
\text { customer of the bank to or with any party not affiliated with the bank for } \\
\text { the purpose of telemarketing or direct mail marketing. } \\
\text { c. The law should allow a customer of a bank to stop or "opt out" of the } \\
\text { sharing by the bank of certain information regarding the customer and, } \\
\text { prior to any such sharing of information, every bank should be required to } \\
\text { inform each of its customers in writing of his or her rights in this respect. } \\
\text { d. The law should prohibit the disclosure of any information of a banking } \\
\text { customer by third parties. }\end{array}$ \\
\hline Description & $\begin{array}{l}\text { Although the Law on the Protection of Personal Data does not specifically cover banking or } \\
\text { financial activities, its provisions indirectly cover the main provisions stated in this good } \\
\text { practice. } \\
\text { The Law on the Protection of Personal Data (Article 5) states that data controllers may } \\
\text { process personal data only with a written consent signed by the subject whose data will be } \\
\text { processed (data subject). The consent must clearly mention the data for which the consent } \\
\text { is granted, the name of the controller and the purpose, as well as the period of time for } \\
\text { which the consent is granted. This consent must then be kept for the time the data may be } \\
\text { processed. } \\
\text { Article } 17 \text { of the same Law states that data controllers have to notify data subjects - and } \\
\text { receive their written consent - before sharing their personal data with any third party. If the } \\
\text { data subject does not provide such consent, the data may not be disclosed to the third party } \\
\text { unless such disclosure is in the public interest. According to Article } 5 \text {, a data subject may } \\
\text { withdraw his or her consent at any time, unless otherwise explicitly agreed by the data } \\
\text { subject and controller. } \\
\text { Article } 17 \text { also states that the data controller may provide personal data to a third party } \\
\text { based on a written request indicating the purpose and legal grounds for the use of the data, } \\
\text { as well as the specific type of personal data requested. The data controller is prohibited } \\
\text { from providing personal data to third parties who are not authorized to process or use the } \\
\text { data according to the Law or in the event that the purpose for using the personal data } \\
\text { requested is contrary to the principles of personal data processing established in Article } 4 \text { of }\end{array}$ \\
\hline
\end{tabular}

${ }^{97}$ See Article 33 of the Payment Transaction Law of both the FBiH and the RS, approved in 2000. 


\begin{tabular}{|c|c|}
\hline & $\begin{array}{l}\text { the Law. Under this provision, a data user may not use personal data for telemarketing or } \\
\text { direct mail marketing. } \\
\text { The Law (Article 22) also mandates that, before collecting personal data, a controller shall } \\
\text { notify the data subject as to: the purpose of data processing; the identity of the controller, } \\
\text { authority or third party who will have access to the data; whether the forwarding of data is } \\
\text { a legal obligation; the consequences to the data subject of refusing to provide personal } \\
\text { data; the cases in which the data subject has the right to refuse to provide personal data; } \\
\text { and the extent to which the personal data collection is voluntary; as well as the right to } \\
\text { access and the right to correct personal data. } \\
\text { The Law also states that the data controller shall keep separate records regarding any } \\
\text { personal data provided as well as the purpose for which it was provided. } \\
\text { There is no specific provision in the Law prohibiting disclosure of personal information by } \\
\text { third parties. }\end{array}$ \\
\hline Recommendation & $\begin{array}{l}\text { The Law on the Protection of Personal Data would benefit from some precision in order to } \\
\text { cover all the provisions included in the good practice, such as: specifying that the } \\
\text { notifications to (banking) customers shall be in writing, and prohibiting disclosure of } \\
\text { personal information of a customer by third parties. }\end{array}$ \\
\hline Good Practice D. 3 & $\begin{array}{l}\text { Permitted Disclosures } \\
\text { The law should: } \\
\text { a. State specific rules and procedures concerning the release to any } \\
\text { government authority of the records of any customer of a bank; } \\
\text { b. State what the government authority may and may not do with any such } \\
\text { records; } \\
\text { c. State what exceptions, if any, apply to these rules and procedures; and } \\
\text { d. Provide penalties for the bank and any government authority for any } \\
\text { breach of these rules and procedures. }\end{array}$ \\
\hline Description & $\begin{array}{l}\text { The legislation does not cover specific rules and procedures concerning the release of } \\
\text { personal information to government authorities or the permitted uses of personal } \\
\text { information by the authorities. } \\
\text { As a general guideline, the Law on the Protection of Personal Data requires all users of data } \\
\text { (including government authorities) to submit a written request of personal data. The request } \\
\text { must indicate the purpose and legal grounds for the use of the personal data and the type } \\
\text { of personal data being requested. The data controller is then authorized by the Law to } \\
\text { provide the requested personal data (after notifying the data subject and receiving the } \\
\text { subject's written consent) to a third party, "if this is necessary for carrying out tasks within } \\
\text { the competence specified by law or for exercising of lawful interests of the user." } \\
\text { In addition, Section } 329 \text { of the Criminal Code deals with "Disclosure of Non-disclosable } \\
\text { Information" as follows: } \\
\text { "For a person who commits disclosure of non-disclosable information which is not an official } \\
\text { secret, if commission thereof is by a State official who has been warned concerning the non- } \\
\text { disclosability of the information or who, in accordance with the law, is liable for the storage } \\
\text { of information, the applicable sentence is custodial arrest or community service, or a fine not } \\
\text { exceeding twenty times the minimum monthly wage." }\end{array}$ \\
\hline Recommendation & There should be regulations specifically covering the provisions stated in this good practice. \\
\hline Good Practice D. 4 & $\begin{array}{l}\text { Credit Bureaus } \\
\text { a. No credit bureau may begin or maintain operations without being licensed } \\
\text { to do so by the appropriate government authority in accordance with the } \\
\text { law. } \\
\text { b. Every bank must ensure the accuracy and credibility of the information it } \\
\text { shares with any licensed credit bureau. }\end{array}$ \\
\hline
\end{tabular}




\begin{tabular}{|c|c|}
\hline & $\begin{array}{l}\text { c. The law or regulations providing for oversight over credit bureaus should } \\
\text { ensure that, amongst other things, the rules relating to consumer } \\
\text { protection: (i) provide for the extent and timeliness of the updating of } \\
\text { information regarding any bank customer; (ii) require that any bank } \\
\text { customer's records be kept confidential, except as may be expressly } \\
\text { permitted by law; (iii) provide clear rules and procedures regarding the } \\
\text { retention period of any credit record; (iv) require that every bank } \\
\text { customer be informed in writing of the retention period; (v) require that } \\
\text { every bank customer has ready, free access to all of his or her credit } \\
\text { reports and be provided with a copy of any or all of his or her reports on } \\
\text { conditions that are transparent; and (vi) provide procedures for correcting } \\
\text { any mistake on a customer's credit report. }\end{array}$ \\
\hline Description & 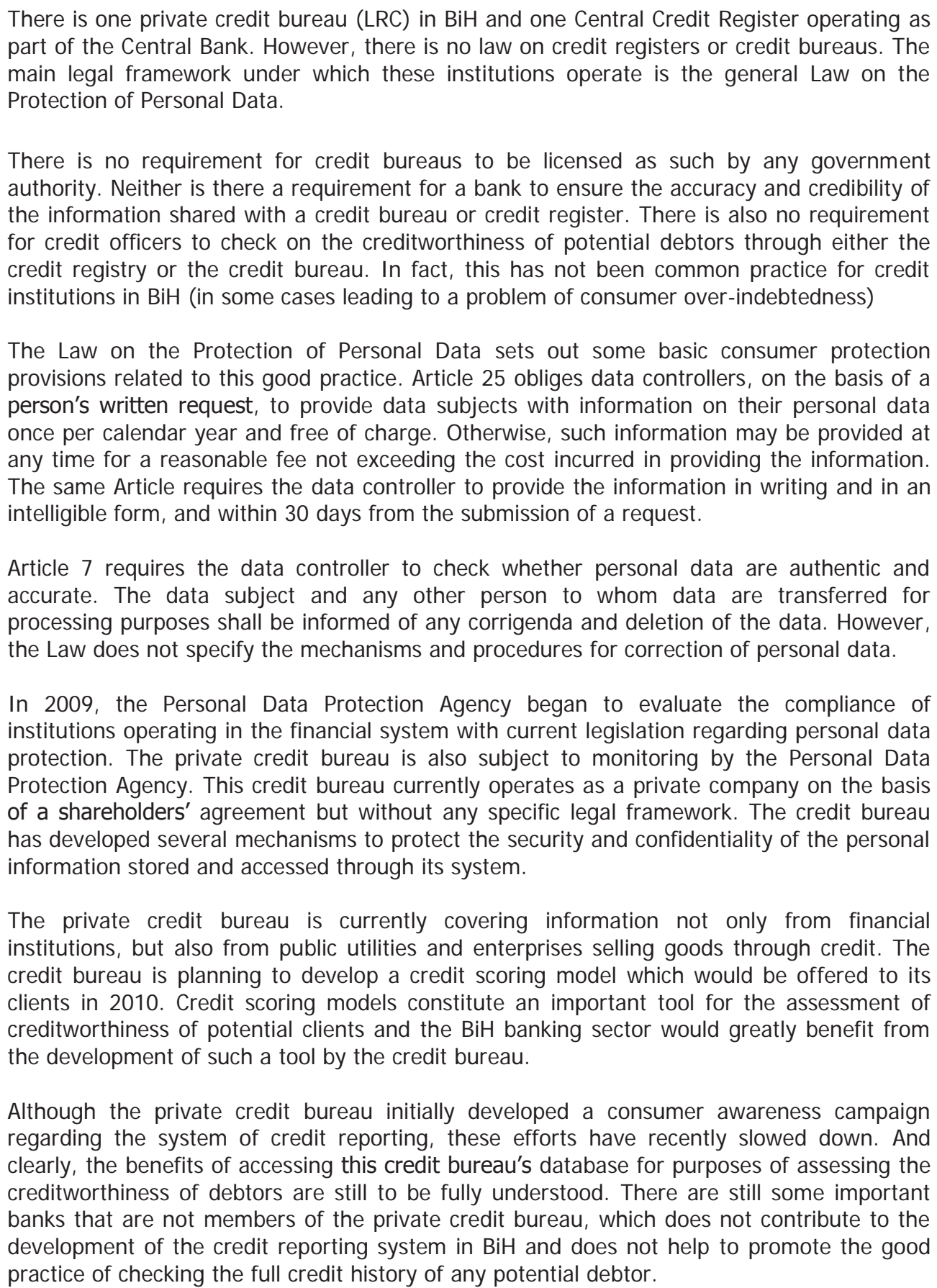 \\
\hline
\end{tabular}




\begin{tabular}{|c|c|}
\hline Recommendation & $\begin{array}{l}\text { There should be a specific legal framework that regulates the operation not only of the } \\
\text { public credit registry, but also of the private credit bureaus in BiH. The legal framework } \\
\text { should include the provisions stated in this good practice. The Personal Data Protection } \\
\text { Agency should be in charge of licensing and monitoring the operation of the credit registry } \\
\text { and credit bureaus. } \\
\text { The Personal Data Protection Agency should publicize the results of its assessment of } \\
\text { compliance of financial institutions with the legal framework on data protection in order to } \\
\text { instill confidence in the market, at least in respect of those financial institutions that have } \\
\text { adequate data protection systems. The Personal Data Protection Agency and the Central } \\
\text { Bank should also provide their technical opinions on the development of credit scoring } \\
\text { models by any private credit bureau. } \\
\text { It would be useful to conduct awareness campaigns for consumers to understand the } \\
\text { importance of keeping a good credit score. It would also be useful to organize workshops } \\
\text { that explain the importance of private credit bureaus for financial market participants, and } \\
\text { their role in promoting sound financial market development. }\end{array}$ \\
\hline SECTION E & DISPUTE RESOLUTION MECHANISMS \\
\hline Good Practice E. 1 & $\begin{array}{l}\text { Internal Complaints Procedure } \\
\text { a. Every bank should have in place a written complaints procedure for the } \\
\text { proper handling of any complaint from a customer, with a summary of this } \\
\text { procedure forming part of the bank's Terms and Conditions referred to in } \\
\text { B. } 7 \text { above. } \\
\text { b. Within a short period of time following the date a bank receives a } \\
\text { complaint, it should: (i) acknowledge in writing to the customer/ } \\
\text { complainant the fact of its receipt of the complaint; and (ii) provide the } \\
\text { complainant with the name of one or more individuals appointed by the } \\
\text { bank to deal with complaint until either the complaint is resolved or } \\
\text { cannot be processed further within the bank. } \\
\text { c. The bank should provide the complainant with a regular written update on } \\
\text { the progress of the investigation of the complaint at intervals of not more } \\
\text { than } 10 \text { business days. } \\
\text { d. Within a few business days of its completion of the investigation of the } \\
\text { complaint, the bank should inform the customer/complainant in writing of } \\
\text { the outcome of the investigation and, where applicable, explain the terms } \\
\text { of any offer or settlement being made to the customer/complainant. } \\
\text { e. When a bank receives a verbal complaint, it should offer the } \\
\text { customer/complainant the opportunity to have the complaint treated by } \\
\text { the bank as a written complaint in accordance with the above. A bank } \\
\text { may not require, however, that a complaint be in writing. } \\
\text { f. A bank should maintain an up-to-date record of all complaints it has } \\
\text { received that are subject to the complaints procedure. For each } \\
\text { complaint, this record should contain the details of the complainant, the } \\
\text { nature of the complaint, a copy of the bank's response(s), a copy of all } \\
\text { other relevant correspondence or records, the action taken to resolve the } \\
\text { complaint and whether resolution was achieved and, if so, on what basis. } \\
\text { The bank should make these records available for review by the banking } \\
\text { supervisor or regulator as and when requested. }\end{array}$ \\
\hline Description & $\begin{array}{l}\text { Although some of the larger banks in } \mathrm{BiH} \text { are in the process of establishing consumer } \\
\text { complaints divisions within their Retail Departments, unfortunately none of the good } \\
\text { practices referred to above has been systematically adopted or applied by banks in BiH. The } \\
\text { prevailing practice in BiH commercial banks has been to deal on an entirely ad hoc basis } \\
\text { with any complaint a consumer raises with the bank within the branch office concerned. } \\
\text { Also, it must be acknowledged that, without ready access to professional legal advice, the }\end{array}$ \\
\hline
\end{tabular}




\begin{tabular}{|c|c|}
\hline & 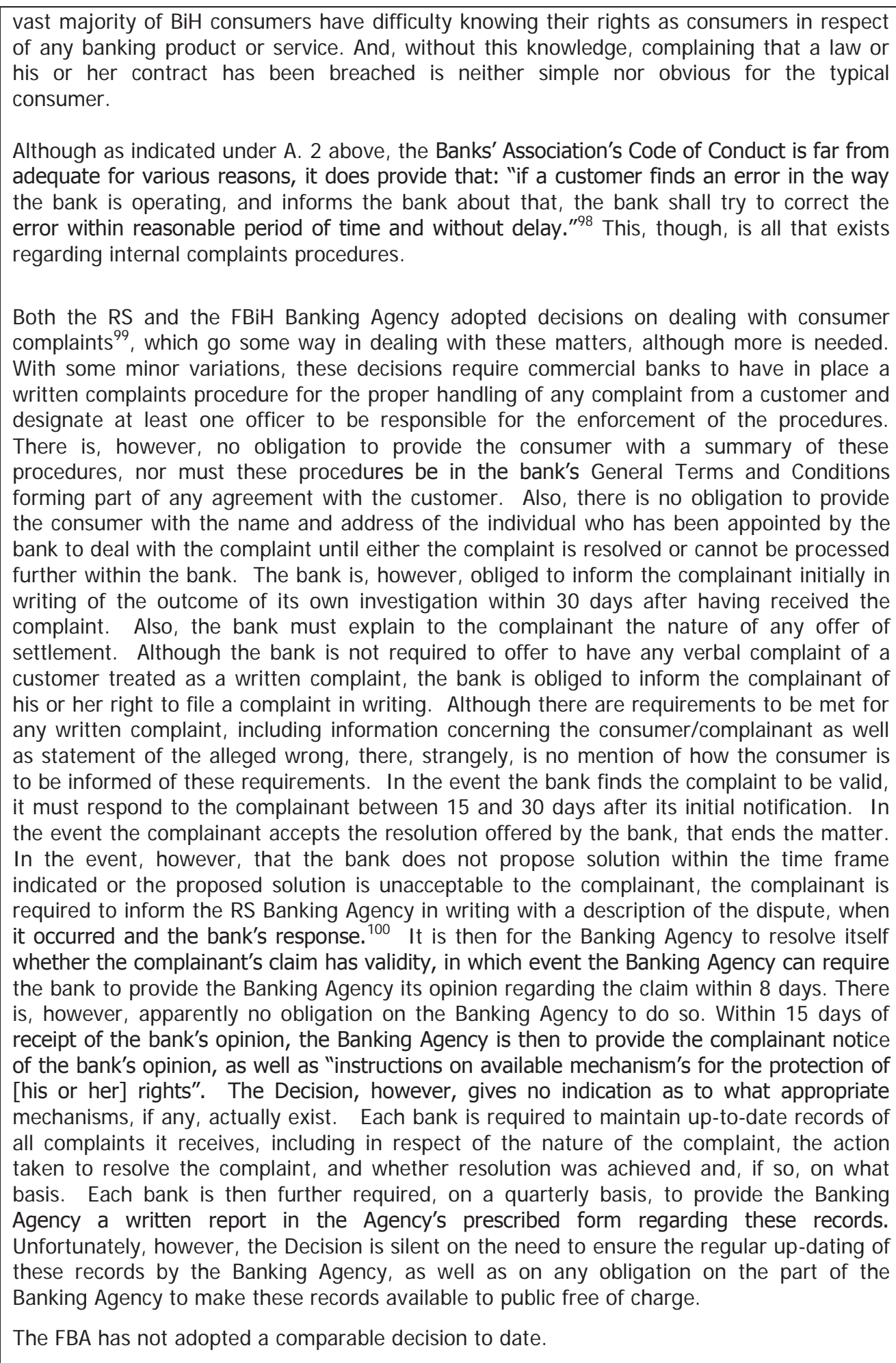 \\
\hline Recommendation & \\
\hline
\end{tabular}

${ }^{98}$ Banks' Association's Code of Ethics, Rule II A) 12

${ }^{99}$ See the Official Gazette of RS, No. 58/10, Official Gazette of the FBiH, 32/10.

${ }^{100}$ It is noteworthy that there is no apparent time limit for a complainant to so inform the Banking Agency. 


\begin{tabular}{|c|c|}
\hline & $\begin{array}{l}\text { (i) to have in place a written complaints procedure for the proper handling of any } \\
\text { complaint from a customer, with a summary of this procedure forming part of } \\
\text { the bank's General Terms and Conditions for any agreement with the customer; } \\
\text { to provide the customer with the name and address of an individual appointed } \\
\text { by the bank to deal with the complaint until either the complaint is resolved or } \\
\text { cannot be processed further within the bank; } \\
\text { to provide the complainant with a regular written update on the progress of the } \\
\text { investigation of the complaint; } \\
\text { to inform the customer/complainant in writing of the outcome of the } \\
\text { investigation within } 30 \text { days after first receiving the complaint; } \\
\text { to explain in simple terms the nature of any offer of settlement being made to } \\
\text { the customer/complainant; } \\
\text { to offer to have any verbal complaint of a customer treated by the bank as a } \\
\text { written complaint in accordance with the above; } \\
\text { to maintain up-to-date records of all complaints it receives, including in respect } \\
\text { of the nature of the complaint, a copy of the bank's response(s), a copy of all } \\
\text { other relevant correspondence or records, the action taken to resolve the } \\
\text { complaint, and whether resolution was achieved and, if so, on what basis; and } \\
\text { to make these records regularly available for review by the Consumer } \\
\text { Ombudsman and applicable Banking Agency or else on the request of that } \\
\text { Office or Agency. } \\
\text { (vii) } \\
\text { Furthermore, there should be a centralized system for the collection and recording of } \\
\text { records should be made public, free of charge, at least on the web on a regular basis. }\end{array}$ \\
\hline Good Practice E. 2 & $\begin{array}{l}\text { Formal Dispute Settlement Mechanisms } \\
\text { a. A system should be in place that allows a customer of a bank to seek } \\
\text { affordable and efficient recourse to a third party banking ombudsman or } \\
\text { equivalent institution in the event the customer's complaint is not } \\
\text { resolved to his or her satisfaction in accordance with the procedures } \\
\text { outlined in E. } 1 \text { above. } \\
\text { b. The existence of, and procedures before, the banking ombudsman or } \\
\text { equivalent institution should be set forth in every bank's Terms and } \\
\text { Conditions referred to in B. } 8 \text { above. } \\
\text { c. The banking ombudsman or equivalent institution should be impartial and } \\
\text { act independently from the appointing authority, the banking industry and } \\
\text { the specific bank with which the complaint has been lodged. } \\
\text { d. The decision of the banking ombudsman or equivalent institution should } \\
\text { be binding upon on the bank with which the complaint has been lodged } \\
\text { and this fact, as well as the mechanism to ensure the enforcement of such } \\
\text { a decision, should be set forth in every bank's Terms and Conditions } \\
\text { referred to in B. } 8 \text { above. }\end{array}$ \\
\hline Description & $\begin{array}{l}\text { In the insurance sector of the RS, the position of RS Insurance Ombudsman was established } \\
\text { within the Insurance Agency of the RS, which provides technical and material conditions for } \\
\text { his/her work. The Ombudsman performs his/her duty independently; he/she is authorized to } \\
\text { receive, follow, and investigate all cases of violation of laws, other regulations, and Code of } \\
\text { Business Ethics, to recommend appropriate general measures, provide information on the } \\
\text { rights and duties of the insured persons, users of insurance, and injured third parties. The } \\
\text { Ombudsman continuously cooperates with insurance companies' representatives, and } \\
\text { through media, on regular basis, informs the public on his/her work, and role related to the } \\
\text { protection of consumers in the insurance sector. }{ }^{101} \\
\text { When disputes raised by consumers are not resolved amicably within a reasonable period, }\end{array}$ \\
\hline
\end{tabular}

${ }^{101}$ See Article 25 of the Law on Insurance Companies of RS (Official Gazette RS, No. 17/05, 1/06, and 64/06), as well as the Insurance Ombudsman's Rulebook and Rules of Procedure. 


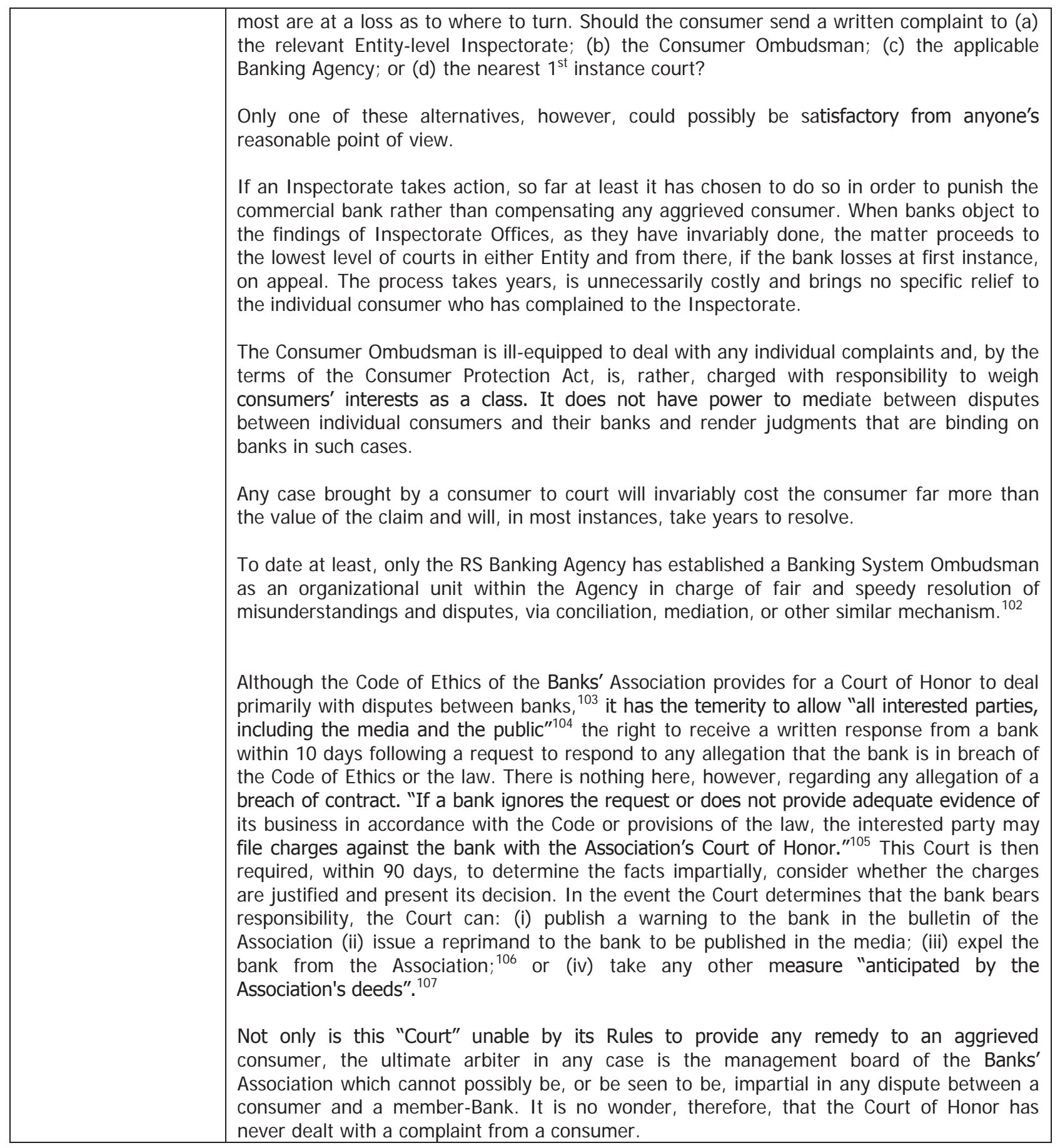

\footnotetext{
102 The Ombudsman was appointed in September 2001, as per Decision on Appointment of the Banking System Ombudsman of the Republika Srpska (Official Gazette RS, No. 70/11)

${ }^{103}$ See paragraphs 2 through 8 of Section II D) of the Code of Ethics.

${ }^{104}$ Query whether this gives standing to an individual consumer to request a response from his or her bank.

105 Note, however, that, by Article 8 of the Rules of Procedure for the Court of Honor, proceedings before the Court "may be initiated by one of the interested parties, members of the Association". Query, therefore, whether, for purposes of the Rules of Procedure, an "interested party" can only be a member of the Association.

${ }^{106}$ Expulsion from Association membership requires: (a) a finding that the bank has repeatedly breached the Code, notwithstanding at least one public warning, [and/or] (b) a finding that the bank has fundamentally hurt the reputation of the banking system, its institutions or individual members of the Association. It is not clear whether "and" or "or" is correct.

${ }^{107}$ Note, however, that no additional measure can bring individual relief to any aggrieved consumer, as such.
} 


\begin{tabular}{|c|c|}
\hline Recommendation & 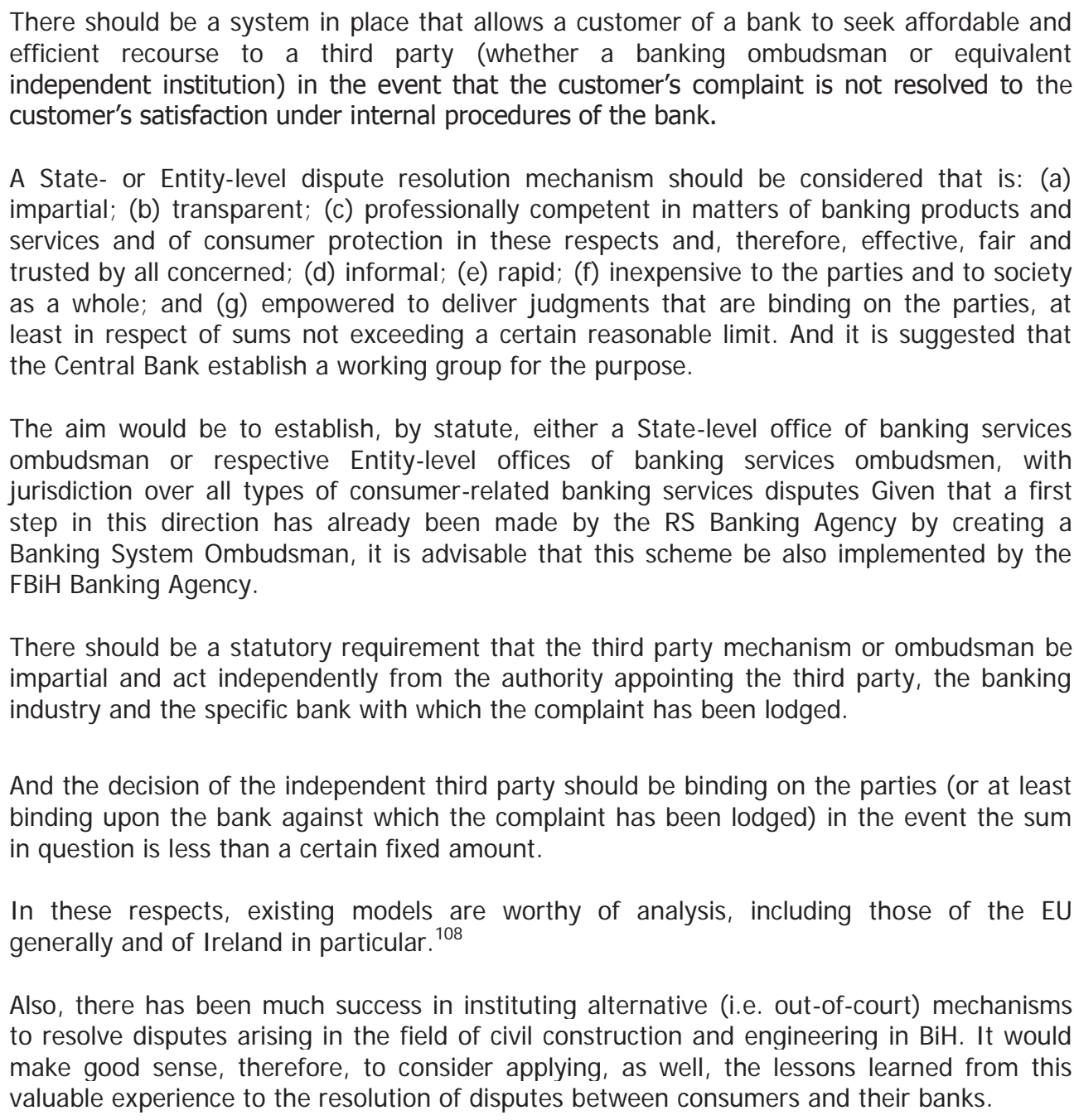 \\
\hline SECTION F & GUARANTEE AND COMPENSATION SCHEMES \\
\hline Good Practice F. 1 & $\begin{array}{l}\text { Depositor Protection } \\
\text { a. The law should ensure that the regulator can take prompt corrective action } \\
\text { on a timely basis. } \\
\text { b. The law on deposit insurance should be clear on: } \\
\text { (i) the insurer; } \\
\text { (ii) the classes of those depositors who are insured; } \\
\text { (iii) the extent of insurance cover; } \\
\text { (iv) the holder of all funds for payout purposes; } \\
\text { (v) the contributor(s) to this fund; } \\
\text { (vi) each event that will trigger a payout from this fund to any class of } \\
\text { those insured; and } \\
\text { (vii)the mechanisms to ensure timely payout to depositors who are }\end{array}$ \\
\hline
\end{tabular}

\footnotetext{
${ }^{108}$ For further information on alternative dispute resolution schemes in Europe and on fundamentals for the establishment of financial ombudsmen, see the consultation draft "Resolving Disputes between Consumers and Financial Businesses", available at http://www.worldbank.org/consumerprotection
} 


\begin{tabular}{|c|c|}
\hline & $\begin{array}{l}\text { insured. } \\
\text { c. In the absence of deposit insurance, there should be an effective and timely } \\
\text { payout mechanism in the event of insolvency of a bank. }\end{array}$ \\
\hline Description & $\begin{array}{l}\text { The Law on Deposit Insurance in Banks of BiH provides for a deposit insurance fund which is } \\
\text { accumulated and managed by the Deposit Insurance Agency of BiH. }{ }^{109} \\
\text { Although all commercial banks operating in BiH are requested to join the deposit insurance } \\
\text { scheme, not all meet the criteria for membership set by the Deposit Insurance Agency. } \\
\text { Member banks are obliged to exhibit the Agency's logo prominently and at all times. } \\
\text { The responsibilities of the Deposit Insurance Agency include: } \\
\text { a) insuring eligible deposits in member banks; } \\
\text { b) issuing membership certificates to those banks that qualify for participation in the } \\
\text { c) investing the assets of the deposit insurance fund. and } \\
\text { d) paying out deposit insurance amounts in respect of depositors holding eligible } \\
\quad \text { deposits on the occasion of a member bank's cessation of operations. }{ }^{110} \\
\text { Although the amount of insured deposit was originally set at the low level of KM } 5,000 \text { and } \\
\text { covered both natural and legal persons, with effect from } 24 \text { December } 2008 \text {, the sum was } \\
\text { increased to KM } 20,000 \text { and coverage restricted to natural persons only. Henceforth, the } \\
\text { Fund's Management Board is authorized to determine the amount of the insured deposit and } \\
\text { have this amended amount take effect on publication in the BiH Official Gazette. } \\
\text { Correspondingly, in April } 2010 \text { the sum was further increased to KM } 35,000 \text {. }{ }^{111} \\
\text { If a depositor has more than one account with the same deposit taker, all accounts are } \\
\text { added together and treated as one account. } \\
\text { The law is clear on each of the matters outlined in b. above and it accords with good } \\
\text { practice. }\end{array}$ \\
\hline Recommendation & No recommendation. \\
\hline Good Practice F. 2 & $\begin{array}{l}\text { Insolvency } \\
\text { a. Depositors should enjoy higher priority than other unsecured creditors in } \\
\text { the liquidation process of a bank. } \\
\text { b. The law dealing with the insolvency of banks should provide for } \\
\text { expeditious, cost effective and equitable provisions to enable the } \\
\text { maximum timely refund of deposits to depositors. }\end{array}$ \\
\hline Description & $\begin{array}{l}\text { The rules regarding bankruptcy proceedings for commercial banks are set forth in the } \\
\text { Entities Laws on Bankruptcy and Liquidation which are generally applicable to legal entities, } \\
\text { as modified, however, by the respective Laws on Banks regarding temporary management, } \\
\text { provisional administration and receivership. } \\
\text { Immediately after payment of the cost of insolvency proceedings, the funds remaining are } \\
\text { distributed, for the satisfaction of the principal sum of creditors' claims, in the following } \\
\text { order of priority: } \\
\text { 1) bank's debts which resulted from advances of funds or other obligations created } \\
\text { during the provisional administration of the bank or its liquidation; } \\
\text { 2) claims by secured creditors up to the value of their security; } \\
\text { 3) claims of the Deposit Insurance Agency for reimbursement of payments of deposits } \\
\text { up to the maximum set out in the Law on Deposit Insurance; } \\
\text { 4) deposits of natural persons, up to a maximum of the equivalent of KM } 35,000 \text { per } \\
\text { depositor; }\end{array}$ \\
\hline
\end{tabular}

\footnotetext{
${ }^{109}$ See Official Gazette of BiH, Nos. 20/02, 18/05, and 100/08.

110 Idem, first paragraph of Article 15.

${ }^{111}$ Decision on the Level of the Insured Deposit (Official Gazette of BiH, No. 29/10)
} 


\begin{tabular}{|c|c|}
\hline & $\begin{array}{l}\text { 5) other deposits, including deposits of natural persons above the equivalent of } \\
\text { KM 35,000 per depositor; } \\
\text { 6) dormant deposits transferred to the Ministry; } \\
\text { 7) claims by other creditors; } \\
\text { 8) claims by shareholders. } \\
\text { Thus, depositors do enjoy higher priority over other unsecured creditors in the liquidation } \\
\text { process of a bank. }\end{array}$ \\
\hline Recommendation & $\begin{array}{l}\text { Query whether the Central Bank Commission, joined for these purposes by the Deposit } \\
\text { Insurance Agency of BiH, should consider to what extent, if at all, the provisions of the Laws } \\
\text { on Banks dealing with the insolvency of banks should be amended to provide more } \\
\text { expeditious, cost effective and equitable provisions with a view to ensuring the maximum } \\
\text { timely refund of deposits to depositors. }\end{array}$ \\
\hline SECTION G & CONSUMER EMPOWERMENT \\
\hline Good Practice G.1 & $\begin{array}{l}\text { Financial Education in Schools } \\
\text { Information about basic financial products, such as current and deposit accounts, } \\
\text { leasing contracts, term loans and mortgages and credit cards, as well as how to } \\
\text { calculate and compare interest rates, should be taught in schools. Schools should } \\
\text { also teach basic financial concepts such as risk vs. return, long-term financial } \\
\text { planning and consequences of over-indebtedness. }\end{array}$ \\
\hline Description & $\begin{array}{l}\text { The public school curriculum does not include the topic of financial education at any level. } \\
\text { However, there are some isolated initiatives that seek to reach students in order to enhance } \\
\text { their financial capabilities. For example, ProCredit Bank has organized seminars oriented } \\
\text { towards school students on the importance of saving money. } \\
\text { Although the } 2009 \text { National Annual Program on Consumer Protection did include one } \\
\text { measure on financial education among its } 100 \text { lines of action, namely: "Raising the level of } \\
\text { awareness and education pertaining financial services", responsibility for carrying this out } \\
\text { fell only to banks and other financial institutions. In its April } 2009 \text { meeting, the EU Expert } \\
\text { Group on Financial Education suggested that the European Commission recommend that all } \\
\text { New Member States of the European Union develop national strategies on financial } \\
\text { education. However, there are apparently no on-going discussions at either Entity level } \\
\text { regarding any financial education strategy or programs. }\end{array}$ \\
\hline Recommendation & $\begin{array}{l}\text { Financial education in schools needs development. The Ministry of Civil Affairs of Bosnia and } \\
\text { Herzegovina, Division of Education, Science, Culture and Sports, should consider the } \\
\text { inclusion of topics on financial education in the public school curriculum. } \\
\text { There is also need to develop a national program on financial education. BiH should take } \\
\text { into account the EU Expert Group on Financial Education's recommendation and start to } \\
\text { develop a national strategy on financial education. }\end{array}$ \\
\hline Good Practice G.2 & $\begin{array}{l}\text { Financial Education through the Media } \\
\text { a. Print and broadcast media should be encouraged to cover issues related } \\
\text { to retail financial products. } \\
\text { b. Regulators and/or industry associations should provide sufficient } \\
\text { information to the press and broadcast media to facilitate analysis of } \\
\text { issues related to financial products and services. }\end{array}$ \\
\hline Description & $\begin{array}{l}\text { Recently, newspapers and radio and television programs have paid more attention to } \\
\text { financial consumer news and the provision of information to consumers, given the issues } \\
\text { last year with changes of interest rates for in some consumer loans. However, a common } \\
\text { perception of specialists working on financial sector issues in BiH is that media coverage has } \\
\text { been less than well-informed and professional. }\end{array}$ \\
\hline
\end{tabular}

${ }^{112}$ See Article 63 of the FBiH Law on Banks. See also the corresponding provision in Article 119 of the RS Law on Banks. 


\begin{tabular}{|c|c|}
\hline & $\begin{array}{l}\text { Journalists need to be educated in order to understand banking services and thus to be able } \\
\text { to cover the stories objectively. Many are concerned that this was not the case in respect of } \\
\text { those journalists who were determined in } 2009 \text { to carry out a smear campaign against all } \\
\text { banks as irresponsible "loan sharks" seeking to maximum profits at the expense of } \\
\text { consumers. } \\
\text { The Central Bank has participated more actively in recent months in providing information } \\
\text { and independent opinion on financial, and more specifically banking, sector issues. }\end{array}$ \\
\hline Recommendation & $\begin{array}{l}\text { More information should be given more frequently by regulators and the banking association } \\
\text { to the media and from the media to the public. There should be a program to provide } \\
\text { financial education or training to journalists covering financial sector issues. }\end{array}$ \\
\hline Good Practice G.3 & $\begin{array}{l}\text { Information Resources for Consumers } \\
\text { a. Financial regulators should seek to improve consumer awareness of } \\
\text { financial products and services by devising, publishing and distributing } \\
\text { independent information on the costs, risks and benefits of such products } \\
\text { and services. } \\
\text { b. Non-governmental organizations should be encouraged to provide } \\
\text { consumer awareness programs to the public regarding financial products } \\
\text { and services. }\end{array}$ \\
\hline Description & 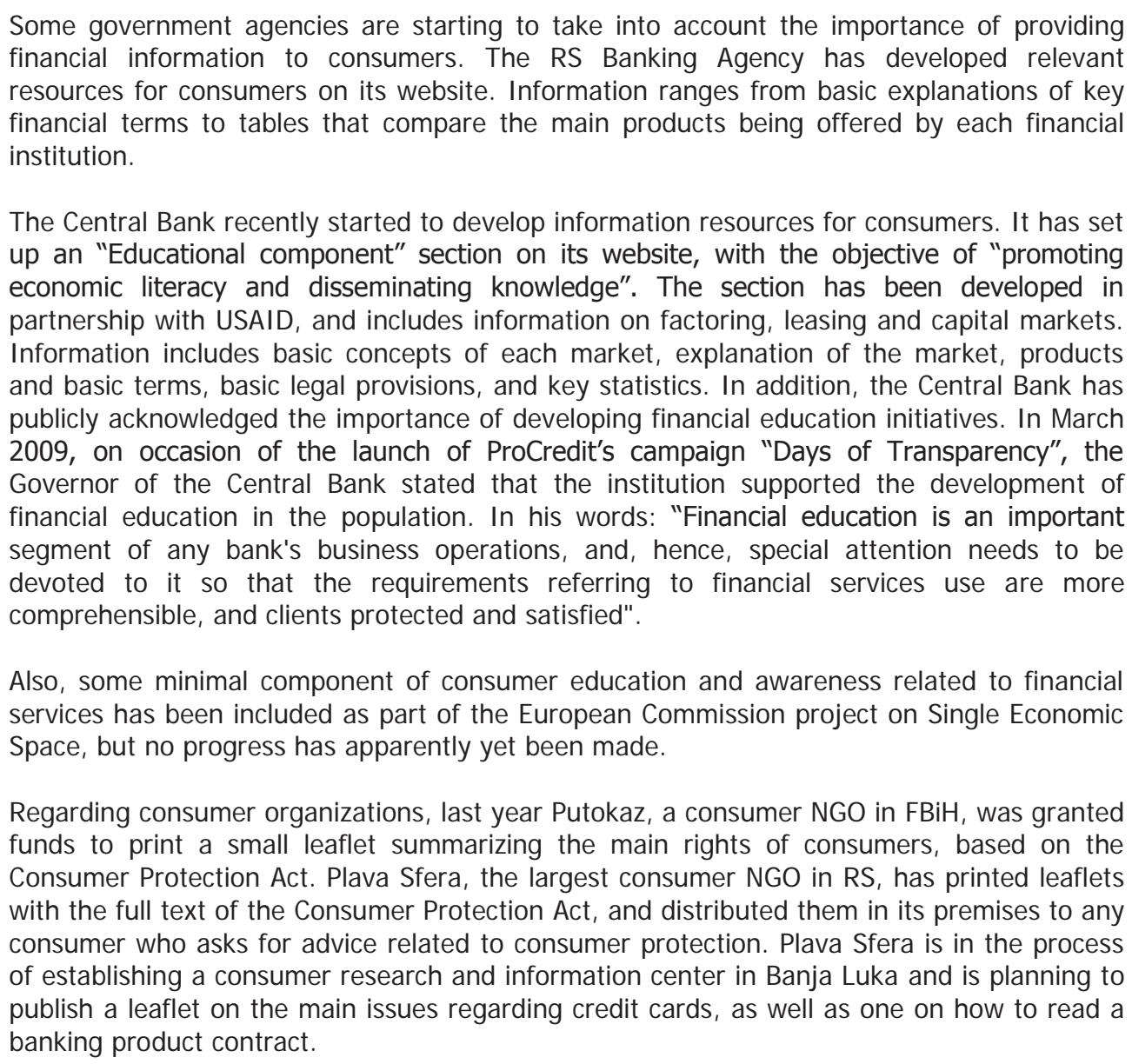 \\
\hline Recommendation & $\begin{array}{l}\text { Government authorities could provide more information in plain language on financial } \\
\text { products and services to improve consumer awareness. } \\
\text { Consumer associations should be more involved in the development of consumer awareness } \\
\text { programs on financial issues. However, consumer NGOs are weak and under-funded, and } \\
\text { even some government funds allocated to them are approved very late in the year, which }\end{array}$ \\
\hline
\end{tabular}




\begin{tabular}{|c|c|}
\hline & works against adequate elaboration of projects and against appropriate planning. \\
\hline Good Practice G.4 & $\begin{array}{l}\text { Financial Consumer Advocacy } \\
\text { In the development of financial sector policy, government and state agencies } \\
\text { need to consult with banks and consumers and their respective associations in } \\
\text { order to develop proposals that meet the needs and expectations of these key } \\
\text { stakeholders. To ensure that consumers are actively involved in the policy } \\
\text { development process, the government, or private sector organizations, should } \\
\text { either provide appropriate funding to non-governmental organizations for this } \\
\text { purpose or create a special entity to lobby on behalf of consumers in the policy- } \\
\text { making process. }\end{array}$ \\
\hline Description & $\begin{array}{l}\text { Although consumer associations are members of the Consumer Protection Council, their } \\
\text { participation seems less than significant. On the one hand, they have problems of stable } \\
\text { sources of funding for the development of their daily activities, as well as a lack of } \\
\text { professional expertise. On the other hand, the umbrella organizations for consumer } \\
\text { associations in each Entity are not well coordinated. As a result, their capacity to conduct } \\
\text { any, let alone effective, consumer advocacy, especially in respect of financial sector issues, } \\
\text { is adversely affected. }\end{array}$ \\
\hline Recommendation & $\begin{array}{l}\text { Consumer associations should play a key role in financial consumer protection since they are } \\
\text { generally the first place consumers go for advice and information, especially in remote areas } \\
\text { of the country. Consumer associations should be allies of the State and the Entities in the } \\
\text { task of protecting consumer rights. But, in order to provide an effective service to } \\
\text { consumers, as well as advocacy for financial consumers in the policy-making process, } \\
\text { consumer associations need adequate and stable sources of funding, as well as significantly } \\
\text { greater institutional capacity. }\end{array}$ \\
\hline Good Practice G.5 & $\begin{array}{l}\text { Measuring Financial Capability } \\
\text { In order to ensure that financial consumer protection, education and information } \\
\text { initiatives are proportionate and appropriate, and in order to measure the } \\
\text { effectiveness of those initiatives over time, the financial capability of consumers } \\
\text { should be measured periodically by way of large-scale market research that gets } \\
\text { repeated from time to time. For these purposes, the term "financial capability of } \\
\text { consumers" means the ability to manage money, keep track of finances, plan } \\
\text { ahead, choose appropriate financial products and services and stay informed } \\
\text { about financial matters. }\end{array}$ \\
\hline Description & $\begin{array}{l}\text { Although some limited surveys on access to finance of micro-credit clients and low-income } \\
\text { households have been conducted in BiH in recent years, no nationwide financial literacy } \\
\text { survey has been conducted in BiH. A survey was funded in October } 2008 \text { by the European } \\
\text { Fund for Southeast Europe (EFSE) in the Tuzla Canton, complemented by focus groups in } \\
\text { Tuzla and Foca. The study included questions on several topics, such as household } \\
\text { composition, availability of financial products, indebtedness, attitudes and consumer } \\
\text { protection. The survey provided information on the level of knowledge of certain financial } \\
\text { concepts, complaints procedures, information received by the credit institution, trust in } \\
\text { respect of financial institutions, attitudes towards savings per household, among other } \\
\text { matters. This constituted a useful step to understanding the level of knowledge, attitudes } \\
\text { and challenges of consumers of financial services particularly in Tuzla. }\end{array}$ \\
\hline Recommendation & $\begin{array}{l}\text { A national survey of financial literacy should be conducted as a first step in the development } \\
\text { of a national program of financial education. A nationwide financial literacy survey would } \\
\text { provide a baseline assessment of the current levels of financial capability and serve as an } \\
\text { essential means for measuring the future impact of consumer protection and financial } \\
\text { education programs. } \\
\text { The survey should be broken down by geographic area, socio-economic levels, years of } \\
\text { formal education, gender, age and other standard variables for sociological studies. } \\
\text { Segmentation would provide policy-makers with insight into the key issues faced by } \\
\text { consumers of banking products and services as these same consumers look for ways to } \\
\text { meet their debts and plan their financial futures. }\end{array}$ \\
\hline
\end{tabular}




\begin{tabular}{|c|c|}
\hline SECTION H & COMPETITION AND CONSUMER PROTECTION \\
\hline Good Practice H. 1 & $\begin{array}{l}\text { Regulatory Policy and Competition Policy } \\
\text { Financial regulators and competition authorities should be required to consult } \\
\text { with one another for the purpose of ensuring the establishment, application and } \\
\text { enforcement of consistent policies regarding the regulation of financial services. }\end{array}$ \\
\hline Description & $\begin{array}{l}\text { By Article } 40 \text { of the FBiH Law on Banks, banks must refrain from entering into transactions } \\
\text { or engaging in practices of any kind that would provide, alone or together with others, a } \\
\text { position of dominance in the financial markets. The RS Law on Banks contains substantially } \\
\text { the same provision. }{ }^{113} \text { As a result, it is the responsibility of the Banking Agencies to ensure } \\
\text { that banks comply. } \\
\text { Notwithstanding, however, that the Banking Agencies are responsible in this way for } \\
\text { ensuring competition in the financial markets and the Competition Council is charged with } \\
\text { enforcing the Law on Competition which applies to all sectors of the BiH economy, including } \\
\text { the delivery of banking services, there is nothing in the law to require any, let alone regular, } \\
\text { consultations among the two Banking Agencies and the Competition Council so as to ensure } \\
\text { consistency in establishing, applying and enforcing financial services regulations. Although } \\
\text { ad hoc consultations do apparently take place from time to time among the Banking } \\
\text { Agencies and the Competition Council to discuss issues of common concern, meetings of this } \\
\text { sort are rare. }\end{array}$ \\
\hline Recommendation & $\begin{array}{l}\text { The Banking Agencies and the Competition Council should be required, by law, to consult } \\
\text { regularly with one another so as to ensure the establishment, application and enforcement } \\
\text { of consistent policies regarding the regulation of financial services generally and pertaining } \\
\text { to competition in the market in particular. }\end{array}$ \\
\hline Good Practice H. 2 & $\begin{array}{l}\text { Review of Competition } \\
\text { Given the significance of retail banking to the economy as a whole and to the } \\
\text { welfare of consumers, competition authorities should: } \\
\text { a. Maintain a watching brief on competition in retail banking; and } \\
\text { b. Conduct and publish periodic assessments of competition in retail } \\
\text { banking, and make recommendations on how competition in retail } \\
\text { banking can be enhanced. }\end{array}$ \\
\hline Description & $\begin{array}{l}\text { The Competition Council of } \mathrm{BiH} \text { is responsible for ensuring the application and enforcement } \\
\text { of the Law on Competition of BiH. It does not maintain, however, any watching brief on } \\
\text { competition in banking. } \\
\text { And the Council, likewise, has not conducted and published any periodic assessments of } \\
\text { competition in retail banking, nor has it made any recommendations as to how, in its view, } \\
\text { competition in retail banking in BiH would be enhanced. }\end{array}$ \\
\hline Recommendation & $\begin{array}{l}\text { The Competition Council should consider conducting and publishing periodic assessments of } \\
\text { competition in retail banking, and make recommendations as to how competition in BiH } \\
\text { retail banking could be enhanced. }\end{array}$ \\
\hline Good Practice H. 3 & $\begin{array}{l}\text { Licensing of Legal Entities } \\
\text { All legal entities that either collect funds from consumers or lend funds to } \\
\text { consumers should be licensed and supervised. }\end{array}$ \\
\hline Description & $\begin{array}{l}\text { All legal entities that either collect funds from consumers or lend funds to consumers are } \\
\text { required to be licensed to operate by the respective Entity's Banking Agency and this Agency } \\
\text { then supervises the operations of these entities. }\end{array}$ \\
\hline
\end{tabular}

${ }^{113}$ See Law on Banks of RS, Article 88. 
Recommendation

No recommendation. 


\section{ANNEX \\ Variable Interest Rate Provisions in Consumer Loans \\ for \\ Discussion Purposes}

The rate of interest on your Loan may vary from time to time and to the extent indicated below as a result solely of a fluctuation in the Base Rate which by Directive ..... of the Banking Agency of the [Federation of BiH][Republic of Srpska] is the Europe Inter Bank Offering Rate ("EURIBOR") as published each weekday in the

The initial annual rate of interest on your Loan is .... \%. This is ...... \% higher than EURIBOR as of the date hereof.

An adjustment to this annual rate may be made every [30][90][120][182][365] days following the date hereof based solely upon EURIBOR that prevails 30 working days prior to the adjustment date, provided that:

a) no single adjustment may result in an increase or decrease in the prevailing rate of ..... \%;

b) the prevailing rate can never exceed _ $\%$ or be less than ..... \%; and

c) you are informed in writing of the proposed new rate not less than 15 working days prior to the date the change in annual interest rate is to take effect (the "adjustment date").

On receipt of this information in writing, you have the following options:

i) do nothing, in which case the new rate will apply to your Loan as of the adjustment date;

ii) pay off the outstanding principal and interest on your Loan prior to the adjustment date without penalty; or

iii) indicate in writing to us that you require the term of your Loan to be extended so that the monthly payments you are making remain essentially the same. 